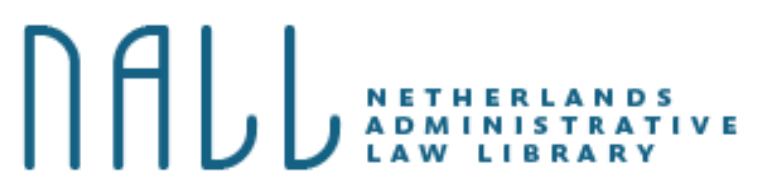

Citeerwijze van dit artikel:

Laura Di Bella, 'Besluitenaansprakelijkheid en causaal verband', NALL 2012, april-juni,

DOI: 10.5553/NALL/.000002

DOI: 10.5553/NALLI.000002

\title{
Besluitenaansprakelijkheid en causaal verband
}

\section{Laura Di Bella}

\section{Inleiding}

In dit artikel staat centraal de toepassing van het vereiste van causaal verband bij de vraag naar aansprakelijkheid van de overheid wegens onrechtmatige besluiten. Het artikel is onderdeel van mijn promotieonderzoek naar de toepassing van de onrechtmatigedaadscriteria bij overheidsaansprakelijkheid in vergelijking met civiele partijen door zowel de civiele rechter als de bestuursrechter. Bij de vraag naar aansprakelijkheid van de overheid voor onrechtmatige besluiten geldt, net als voor daden van civiele partijen, het vereiste van causaal verband. De bestuursrechter sluit bij de beoordeling of sprake is van causaal verband ook aan bij het civiele schadevergoedingsrecht en de bewoordingen van artikel 6:98 BW. ${ }^{\mathbf{1}}$ Desondanks wijkt de toepassing van het causaliteitsvereiste door de rechter bij besluitenaansprakelijkheid af van de toepassing ervan bij andere onrechtmatige daden. Deze afwijkende toepassing doet zich voornamelijk voor bij de bestuursrechter. De jurisprudentie van de civiele rechter over onrechtmatige besluiten geeft in veel mindere mate blijk van een afwijkende benadering.

Over het onderwerp bestaat nog geen eenduidigheid en de literatuur is overwegend kritisch over de huidige stand van de jurisprudentie. ${ }^{2}$ Dit artikel beoogt ten eerste de afwijkingen in kaart te brengen. Ten tweede onderzoekt en beoordeelt het (mogelijke) redenen voor de geconstateerde verschillen. ${ }^{3}$ Doel van het onderzoek is om op deze manier meer inzicht te krijgen in de positie van de overheid in het onrechtmatigedaadsrecht en de omvang van de overheidsaansprakelijkheid wegens onrechtmatige daad.

Ten slotte: het artikel is omvangrijk. Dit wordt mijns inziens gerechtvaardigd door de omvang en het belang van het onderwerp. Het vereiste van causaal verband is in de praktijk een belangrijk instrument bij bepaling van de vestiging en omvang van de aansprakelijkheid wegens onrechtmatige daad. Dit artikel beoogt een compleet beeld te geven van de toepassing van dit vereiste bij besluitenaansprakelijkheid. Het onderwerp is zoals gezegd nog niet uitgekristalliseerd en levert fundamentele kritiek uit de literatuur op. 


\section{Opzet van het artikel}

Voor recht op schadevergoeding wegens onrechtmatige daad is vereist dat een rechtens relevant causaal verband bestaat tussen de onrechtmatige daad en de geleden schade. Voor de bepaling van het causaal verband moet eerst helder zijn wat de onrechtmatige, schadeveroorzakende gebeurtenis is waarmee causaal verband dient te bestaan. In het geval van schade, veroorzaakt door een vernietigde (en dus onrechtmatige) beslissing op bezwaar, speelt bij de vaststelling van het causaal verband de vraag of ook schade veroorzaakt door het primaire besluit voor vergoeding in aanmerking komt. Deze voorvraag over de schadeveroorzakende gebeurtenis komt aan de orde in paragraaf 3.

Het causaliteitsvereiste omvat twee aspecten. Ten eerste dient een feitelijk causaal verband te bestaan tussen de onrechtmatige daad en de schade: als hoofdregel geldt dat sprake moet zijn van een 'condicio sine qua non verband'. Dit houdt in dat geen causaal verband bestaat als de schade zich ook zonder de onrechtmatige daad had voorgedaan. Ten tweede moet de schade ingevolge artikel 6:98 BW redelijkerwijs kunnen worden toegerekend aan de onrechtmatige daad. Dit betreft het juridisch causaal verband. Ook dit artikel houdt de genoemde tweedeling aan. Één conclusie van het onderzoek naar causaal verband bij onrechtmatige overheidsbesluiten is dat bestuursrechters bij het bepalen van het causaal verband vaak geen (duidelijk) onderscheid maken tussen condicio sine qua non verband en toerekening. Dit wordt in paragraaf 4 behandeld. In paragraaf 5 staat het condicio sine qua non vereiste centraal. Paragraaf 6 bespreekt toepassing van de toerekeningsleer op grond van artikel 6:98 BW. De aanpak is per (deel)paragraaf steeds gelijk. Eerst beschrijft het in het algemeen de inhoud en betekenis van het betreffende onderdeel van het vereiste van causaal verband. Hiermee vergelijkt het vervolgens de toepassing ervan in het geval van onrechtmatige besluiten. De geconstateerde verschillen worden benoemd en beoordeeld. Paragraaf 7 bevat de conclusie.

\section{Een voorvraag: komt ook schade veroorzaakt door het primaire besluit voor vergoeding in aanmerking indien de beslissing op bezwaar is vernietigd?}

Indien de beslissing op bezwaar door de bestuursrechter is vernietigd staat de onrechtmatigheid daarvan vast. ${ }^{4}$ De schade wordt echter vaak (mede) veroorzaakt door hetgeen is bepaald in de voorafgaande primaire beslissing die niet is vernietigd. De vraag rijst of ook de door het primaire besluit veroorzaakte schade voor vergoeding in aanmerking komt. Deze vraag ziet strikt genomen meer op de onrechtmatigheid dan op het causaal verband, omdat het erover gaat of met onrechtmatigheid van de beslissing op bezwaar ook de primaire beslissing als onrechtmatig beschouwd wordt. Toch kan het onderwerp naar mijn mening in dit artikel niet geheel buiten beschouwing blijven. Om causaal verband te kunnen vaststellen moet immers eerst duidelijk zijn met welke onrechtmatige gebeurtenis causaal verband dient te bestaan. Indien het primaire besluit onrechtmatig is, komt (ook) schade die in causaal verband daarmee staat voor vergoeding in aanmerking. Zo niet, dan dient de beslissing op bezwaar uitgangspunt te zijn voor het vaststellen van causaal verband. De bestuursrechter en de civiele rechter hanteren hier een andere lijn. $\mathbf{5}$ Volgens de Afdeling bestuursrechtspraak van de Raad van State kan uit de 
rechterlijke uitspraak, waarin de beslissing op bezwaar wordt vernietigd, worden afgeleid dat deze onrechtmatigheid mede ziet op het primaire besluit. ${ }^{\mathbf{6}}$ Dit is het geval indien het geconstateerde gebrek ook aan het primaire besluit kleeft. In dit kader maakt het voor de Afdeling geen verschil of het gebrek formeel of materieel van aard is. Dit aspect speelt overigens wel een rol bij het bewijs van causaal verband. ${ }^{7}$ Ook is de uitkomst van eventuele toekomstige besluitvorming niet van belang voor de vraag of het primaire besluit onrechtmatig is.

De benadering van de Hoge Raad wijkt hiervan af. De Hoge Raad stelt in zijn rechtspraak voorop dat met de vernietiging van de beslissing op bezwaar nog niet vaststaat dat ook het primaire besluit onrechtmatig is. Het antwoord op de vraag of het primaire besluit rechtmatig of onrechtmatig is hangt volgens de Hoge Raad in het algemeen af van de besluitvorming die na de vernietiging van de beslissing op bezwaar plaatsvindt. Indien de uitkomst van de bestuursrechtelijke procedure er (uiteindelijk) toe leidt dat het primaire besluit in stand blijft en onherroepelijk wordt, moet de burgerlijke rechter ervan uitgaan dat het primaire besluit rechtmatig is. ${ }^{\mathbf{8}}$ In die gevallen moet dus voor het bepalen van het causaal verband de vernietigde beslissing op bezwaar als de onrechtmatige daad worden gezien. De schade wordt echter meestal geleden door hetgeen in het primaire besluit is bepaald en dat op bezwaar wordt gehandhaafd. Het is in de huidige stand van de jurisprudentie mijns inziens nog niet duidelijk of de Hoge Raad in dergelijke gevallen van mening is dat geen causaal verband bestaat tussen de schade en het besluit, omdat deze wordt veroorzaakt door de in zijn ogen rechtmatige primaire beslissing, of dat deze schade wel vergoedbaar kan zijn vanaf het moment dat het onrechtmatige besluit op bezwaar is genomen. 9

\section{Onderscheid condicio sine qua non en toerekening}

\subsection{Algemeen}

Als voorwaarde voor aansprakelijkheid uit onrechtmatige daad bestaat in het civiele recht het vereiste van causaal verband tussen onrechtmatige daad en schade. Dit blijkt ten eerste uit het woord "dientengevolge" van artikel 6:162 lid 1 BW:

"Hij, die jegens een ander een onrechtmatige daad pleegt, welke hem kan worden toegerekend, is verplicht de schade die de ander dientengevolge lijdt, te vergoeden."

Als 'minimumvereiste' voor de aanwezigheid van causaal verband geldt als hoofdregel dat sprake moet zijn van een 'condicio sine qua non verband' ${ }^{\mathbf{1 0}} \mathrm{Dit}$ betekent dat in ieder geval geen causaal verband bestaat tussen de onrechtmatige daad en de schade als deze schade zich ook zonder de onrechtmatige daad had voorgedaan. Om vast te kunnen stellen of is voldaan aan het vereiste van condicio sine qua non moet men de onrechtmatige daad wegdenken en bepalen of de betreffende schade in die hypothetische situatie al dan niet geleden zou zijn. ${ }^{\mathbf{1 1}}$ Indien het antwoord ontkennend luidt, dan wordt een condicio sine qua non verband aangenomen tussen de onrechtmatige daad en de schade. Is het antwoord op deze vraag bevestigend, dan is geen sprake van een condicio sine qua non verband. Het condicio sine qua non verband is, zoals 
gezegd, een minimumvereiste voor de vestiging van aansprakelijkheid. Het wordt echter niet geschikt geacht als enige aan het causaal verband te stellen eis, omdat dit tot een te vergaande aansprakelijkheid zou leiden. ${ }^{\mathbf{1 2}}$

Om het causaal verband nader te bepalen geldt de toerekeningsleer, welke is verwoord in artikel 6:98 BW:

"Voor vergoeding komt slechts in aanmerking schade die in zodanig verband staat met de gebeurtenis waarop de aansprakelijkheid van de schuldenaar berust, dat zij hem, mede gezien de aard van de aansprakelijkheid en van de schade, als een gevolg van deze gebeurtenis kan worden toegerekend."

In de praktijk zal de rechter bij de beoordeling van het causaal verband eerst vaststellen of sprake is van een condicio sine qua non verband tussen de gepleegde onrechtmatige daad en de geleden schade. Is dat inderdaad het geval, dan pas komt de vraag aan de orde of de schade in redelijkheid aan deze daad kan worden toegerekend. De Hoge Raad:

\footnotetext{
"Van het in art. 6:98 BW bedoelde oorzakelijk verband kan overigens eerst sprake zijn, indien is voldaan aan de eis van condicio-sine-qua-non-verband als bedoeld in art. 6:162 BW."13
}

In de rechterlijke uitspraak komt met betrekking tot het causaal verband het condicio sine qua non verband echter niet altijd uitdrukkelijk aan de orde, omdat het bestaan ervan dan vanzelfsprekend is en geen onderwerp in het geschil tussen partijen. ${ }^{\mathbf{1 4}}$

In het civiele aansprakelijkheidsrecht geldt ingevolge artikel 6:102 lid $1 \mathrm{BW}$ het principe van de hoofdelijke aansprakelijkheid: indien meerdere personen aansprakelijk zijn voor dezelfde schade kan de benadeelde ieder van hen voor het geheel van de schade aanspreken. Vervolgens kunnen de aansprakelijke partijen onderling regres nemen. Zij zijn op grond van artikel 6:10 BW ieder aansprakelijk voor het gedeelte van hun schuld.

Artikel 6:101 BW bepaalt dat, wanneer de schade mede een gevolg is van een omstandigheid die aan de benadeelde kan worden toegerekend, de vergoedingsplicht wordt verminderd door de schade over de benadeelde en de vergoedingsplichtige te verdelen in evenredigheid met de mate waarin de aan ieder toe te rekenen omstandigheden tot de schade hebben bijdragen, tenzij uit de billijkheid anders voortvloeit.

\subsection{Geen duidelijk onderscheid condicio sine qua non en toerekeningsleer bij besluitenaansprakelijkheid}

\subsubsection{Inleiding}

In paragraaf 4.1. wordt vastgesteld dat voor het aannemen van causaal verband eerst voldaan moet zijn aan de eis van condicio sine qua non verband voordat sprake kan zijn van het in art. 6:98 BW bedoelde oorzakelijk verband. Bij de beantwoording van de vraag of sprake is van causaal verband dient de rechter dus deze twee aspecten te onderscheiden. ${ }^{\mathbf{1 5}}$ In de bestuursrechtspraak wordt dit onderscheid naar mijn mening vaak niet (duidelijk) gemaakt. 


\subsubsection{Rechtspraak}

In de meeste uitspraken van de bestuursrechter over causaal verband wordt, steeds in gelijksoortige bewoordingen, voorop gesteld dat slechts voor vergoeding in aanmerking komt schade, die in een zodanig verband staat tot het onrechtmatige besluit dat zij aan het bestuursorgaan dat dat besluit heeft genomen, mede gezien de aard van de aansprakelijkheid en van de schade, als een gevolg van dat besluit moet worden toegerekend. Hij sluit hiermee dus aan bij de bewoordingen van artikel 6:98 BW over de toerekening. Vervolgens gaat hij echter regelmatig niet in op de rechtsvraag op grond van welke objectieve criteria de schade wel of niet dient te worden toegerekend, maar oordeelt hij over de feitelijke vraag of de schade al dan niet door het onrechtmatige besluit is veroorzaakt. Deze conclusie zal ik hieronder toelichten aan de hand van een aantal uitspraken.

De uitkeringsinstantie heeft aan een werknemer een uitkering op grond van de Ziektewet geweigerd. ${ }^{\mathbf{1 6}}$ Dit blijkt onterecht en het besluit wordt uiteindelijk door de Centrale Raad van Beroep vernietigd. Ondertussen is de werknemer echter door zijn werkgever ontslagen en spreekt hij de uitkeringsinstantie aan voor de hierdoor ontstane schade. Hij is van mening dat indien de instantie destijds niet het onjuiste besluit ten aanzien van de weigering van het ziekengeld had genomen, hij nimmer de betrekking bij zijn werkgever zou zijn kwijtgeraakt. In de uitspraak over de schadevergoeding stelt de Raad voorop dat:

"Wil appellants verzoek toegewezen kunnen worden, genoegzaam aannemelijk zal moeten zijn dat dit nadeel in een zodanig verband staat met het vernietigde besluit van 24 januari 1994, dat dit appellant, mede gezien de aard van de aansprakelijkheid en van de schade, als een gevolg van dat besluit kan worden toegerekend."

De Raad bekijkt vervolgens de feiten en wijst de schadevordering af wegens het ontbreken van causaal verband. De Raad overweegt dat tussen het ontslag en de onrechtmatige weigering van het ziekengeld geen zodanig verband bestaat dat de schade aan het bestuursorgaan kan worden toegerekend als gevolg van dit besluit. Volgens de Raad is niet komen vast te staan dat de oud-werknemer bij het voortduren van zijn arbeidsongeschiktheid wel bij zijn werkgever in een voor hem uit medisch oogpunt passende functie in dienst had kunnen blijven. De schadevordering wordt dus afgewezen, omdat niet vast staat dat de werknemer niet was ontslagen indien een rechtmatig besluit was genomen. Dit ziet op het ontbreken van een condicio sine qua non verband. In de uitspraak komt dit echter niet uit de verf.

Ook in de volgende uitspraak van de Centrale Raad van Beroep is dit aan de orde. Appellant heeft op grond van foutieve informatie van de gemeente afgezien van een sollicitatie en vordert schadevergoeding. ${ }^{17} \mathrm{Om}$ in deze zaak te bepalen of sprake is van causaal verband overweegt de Raad dat:

"Nagegaan dient te worden wat er gebeurd zou zijn, indien appellant wel had gesolliciteerd."

De Raad meent dat indien de appellant wel had gesolliciteerd, zijn kans op benoeming als uiterst gering moet worden gekwalificeerd. Deze redenering heeft 
betrekking op het ontbreken van een condicio sine qua non verband: ook zonder de onrechtmatige daad was de schade geleden. De Raad wijst de vordering echter af in bewoordingen, die erop duiden dat niet is voldaan aan het toerekeningsvereiste van artikel 6:98 BW:

\begin{abstract}
"Niet staande kan worden gehouden dat de hier besproken schade in zodanig verband staat met de onrechtmatige handeling dat zij, mede gezien de aard van de aansprakelijkheid en van de schade, als een gevolg van die handeling aan de gedaagde [...] zou kunnen worden toegerekend."
\end{abstract}

Ook in de rechtspraak van de Afdeling bestuursrechtspraak komt het onderscheid tussen condicio sine qua non en toerekening vaak niet duidelijk naar voren. Het criterium voor het bepalen van causaal verband bij besluitenaansprakelijkheid formuleert de Afdeling als volgt:
"Van schade, geleden ten gevolge van dat besluit, in evenbedoelde zin is echter slechts sprake, indien deze hiermee in een zodanig verband staat, dat zij aan het bestuursorgaan dat dat besluit heeft genomen, mede gezien de aard van de aansprakelijkheid en van de schade, als een gevolg van dat besluit moet worden toegerekend. Dat is niet het geval, indien ten tijde van het nemen van het rechtens onjuiste besluit een rechtmatig besluit zou hebben kunnen worden genomen, dat naar aard en omvang eenzelfde schade tot gevolg zou hebben gehad". 18

Uit deze overweging blijkt naar mijn mening dat de Afdeling meent dat de schade niet als een gevolg van het onrechtmatige besluit aan het bestuursorgaan kan worden toegerekend indien ten tijde van het nemen van dit besluit een rechtmatig besluit zou hebben kunnen worden genomen, dat naar aard en omvang eenzelfde schade tot gevolg zou hebben gehad. Het feit dat het bestuursorgaan in plaats van het onrechtmatige besluit een rechtmatig besluit had kunnen nemen dat dezelfde schade tot gevolg zou hebben gehad, lijkt mij echter een antwoord op de feitelijke vraag of de schade al dan niet is veroorzaakt door het onrechtmatige besluit en geen toepassing van de toerekeningsleer. Dit wordt bevestigd door het vervolg van de uitspraak, waarin de Afdeling de bewijslast van het causaal verband op het bestuursorgaan legt. Bewijsregels zijn immers alleen aan de orde bij de vraag naar de feitelijke veroorzaking van de schade. De vraag of de schade kan worden toegerekend is een rechtsvraag, die zich niet leent voor bewijslevering. ${ }^{\mathbf{1 9}}$ Ook in andere uitspraken koppelt de bestuursrechter - ten onrechte - het toerekeningsvereiste aan het leveren van bewijs. ${ }^{20}$

In paragraaf 6.2.2. komt aan de orde dat de bestuursrechter regelmatig schadevorderingen afwijst, omdat deze volgens hem worden veroorzaakt door andere omstandigheden dan het onrechtmatige besluit. Deze conclusie geeft de Centrale Raad van Beroep vorm door eerst het toerekeningsvereiste te stellen en vervolgens te bepalen dat daaraan niet is voldaan. In werkelijkheid gaat het in sommige van deze uitspraken naar mijn mening echter over de vraag naar de feitelijke veroorzaking van de schade. ${ }^{\mathbf{2 1}}$

Voor de geconstateerde afwijking wordt in de besproken jurisprudentie geen reden gegeven. 


\subsubsection{Literatuur}

Ook in de literatuur wordt gesignaleerd dat in de bestuursrechtspraak het onderscheid tussen beide aspecten van causaal verband niet altijd duidelijk wordt gemaakt.

Volgens Schlössels blijft, anders dan bij de burgerlijke rechter het onderscheid tussen het vaststellen van causaal verband tussen de daad en schade en de toerekeningsproblematiek van art. 6:98 BW vaak onderbelicht. ${ }^{\mathbf{2 2}}$

Kortmann geeft aan dat het causaliteitscriterium van de Afdeling bestuursrechtspraak eerst aansluiting zoekt bij de leer van de redelijke toerekening van artikel 6:98 BW. Vervolgens heeft de uitwerking hiervan naar zijn mening echter betrekking op de feitelijke vraag naar het condicio sine qua non verband. Hetzelfde fenomeen is volgens hem zichtbaar in de jurisprudentie van de Centrale Raad van Beroep over vernietigde uitkeringsbesluiten. ${ }^{\mathbf{3}}$ Van Ravels vraagt zich met betrekking tot dit causaliteitscriterium af of de causaliteitsoverwegingen zien op het condicio sine qua non verband of het verband bedoeld in artikel 6:98 BW. Naar de mening van Van Ravels doet de betreffende formulering onvoldoende uitkomen dat het condicio sine qua non verband en het toerekeningsvereiste twee te onderscheiden vereisten voor causaal verband zijn. Op het eerste gezicht lijken volgens hem in de formulering, die door de Afdeling wordt gehanteerd, beide eisen te zijn ondergebracht. Hij neemt echter aan dat de Afdeling hiermee niet heeft bedoeld af te wijken van het in het BW bepaalde en de benadering die door de Hoge Raad wordt gevolgd, inhoudende dat van een verband als bedoeld in artikel 6:98 BW eerst sprake kan zijn als voldaan is aan het vereiste van condicio sine qua non. Hij zou ook niet weten welke bestuursrechtelijke bijzonderheden voldoende aanleiding zouden kunnen geven voor een afwijkende benadering op dit punt. Daarvan uitgaande meent hij dat de Afdeling in de bedoelde overwegingen slechts een oordeel heeft gegeven over het condicio sine qua non verband.

Schueler en Van Ettekoven valt het op dat als men de rechtspraak van de Centrale Raad van Beroep vergelijkt met die van de burgerlijke rechter op dit punt het onderscheid tussen de condicio sine qua non eis en die van het vereiste van toerekening door de eerstgenoemde niet of nauwelijks tot uitdrukking wordt gebracht. $^{\mathbf{2 4}}$

\subsection{Beoordeling en conclusie}

In deze paragraaf wordt geconstateerd dat de bestuursrechtspraak vaak geen (duidelijk) onderscheid maakt tussen de feitelijke vraag of de schade al dan niet door het onrechtmatige besluit is veroorzaakt en de rechtsvraag of de schade op grond van objectieve factoren kan worden toegerekend. Dit wijkt af van het systeem van het Burgerlijk Wetboek en de rechtspraak van de civiele rechter. Ook de literatuur signaleert dit verschil. De bestuursrechter geeft in de bedoelde uitspraken geen reden voor deze afwijking van het civiele recht. In de literatuur worden evenmin (mogelijke) rechtvaardigingsgronden aangevoerd voor het onderscheid. Zelf zie ik hiervoor ook geen reden. Het lijkt mij aan te bevelen dat de bestuursrechter aansluit bij het civiele recht door in zijn uitspraken een duidelijk(er) onderscheid te maken tussen het feitelijk causaal verband en de toerekening. Dit bevordert de rechtseenheid. Ook wordt zo voor beide aspecten van het causaliteitsvereiste beter zichtbaar welke omstandigheden ten grondslag 
liggen aan de beoordeling door de bestuursrechter hiervan. Op deze manier neemt de rechtszekerheid toe.

Mocht de bestuursrechter op dit punt wel bewust afwijken van het civiele recht dan verdient het naar mijn mening de voorkeur als hij zowel zijn beweegreden hiervoor als zijn methode voor de beoordeling van het causaal verband kenbaar maakt, zodat hierover geen onduidelijkheid kan bestaan.

\section{Condicio sine qua non verband}

\subsection{Besluitenaansprakelijkheid en het vereiste van een condicio sine qua non verband}

\section{1 .1 Inleiding}

Kort gezegd is voldaan aan het vereiste van condicio sine qua non als de schade zich niet had voorgedaan wanneer de onrechtmatige daad niet was gepleegd. ${ }^{\mathbf{2 5}}$ De vraag naar het condicio sine qua non verband is dus een feitelijke vraag. De uitspraken van de Afdeling van 15 december 2004 over het causaliteitsvereiste kwamen in paragraaf 4.2.2. al aan de orde. ${ }^{\mathbf{2 6}}$ Zoals gezegd formuleert de Afdeling in deze uitspraken naar mijn mening een criterium met betrekking tot de feitelijke oorzaak van de schade. In deze paragraaf wordt het gehanteerde criterium vergeleken met het condicio sine qua non vereiste.

\subsubsection{Rechtspraak}

De Afdeling overweegt dat geen sprake is van causaal verband indien:

"ten tijde van het nemen van het rechtens onjuiste besluit een rechtmatig besluit zou hebben kunnen worden genomen, dat naar aard en omvang eenzelfde schade tot gevolg zou hebben gehad."27

Het oordeel houdt dus in dat de schade geen gevolg is van het onrechtmatige besluit als deze ook had kunnen worden veroorzaakt door een rechtmatig besluit. Het condicio sine qua non vereiste, zoals dat wordt toegepast door de civiele rechter, houdt in dat geen sprake is van causaal verband als de schade ook zonder de onrechtmatige daad zou zijn veroorzaakt. Toegepast op besluitenaansprakelijkheid betekent dit criterium mijns inziens dat geen sprake is van een condicio sine qua non verband indien in plaats van het onrechtmatige besluit een rechtmatig besluit 'zou zijn genomen' dat dezelfde schade zou hebben veroorzaakt. ${ }^{\mathbf{2 8}}$ Dit wijkt dus af van het criterium dat de Afdeling hanteert. 29

De Hoge Raad sluit bij besluitenaansprakelijkheid wel aan bij het 'civiele' condicio sine qua non vereiste. Dit blijkt uit de volgende zaak. Een onderneming in het drogen van gewassen heeft van de gemeente Steenbergen een Hinderwetvergunning gekregen. ${ }^{\mathbf{3 0}}$ Aan deze vergunning zijn beperkende voorwaarden verbonden. Volgens de eigenaar van het bedrijf zijn de voorwaarden zo strikt en controleert de gemeente naleving ervan zo actief, dat hij wordt gedwongen zijn bedrijf te verplaatsen. Dit doet hij ook. In beroep wordt de Hinderwetvergunning vernietigd. Het blijkt dat voor de bedrijfsactiviteiten geen Hinderwetvergunning bij de gemeente, maar een vergunning op grond van de Afvalstoffenwet bij de Provincie vereist was. Het 
bedrijf dient daarop een vordering tot schadevergoeding wegens de bedrijfsverplaatsing tegen de gemeente in. De Gemeente voert tegen de claim aan dat het causaal verband ontbreekt omdat door Gedeputeerde Staten aan een vergunning ingevolge de Afvalstoffenwet dezelfde voorschriften zouden zijn verbonden als aan de vernietigde Hinderwetvergunning. Het Hof is van mening dat als dit inderdaad het geval is het vereiste causaal verband ontbreekt, omdat de schade dan ook zou zijn geleden als de Gemeente niet onrechtmatig had gehandeld, en geeft aan de gemeente de bewijsopdracht van deze stelling. De gemeente slaagt in zijn bewijsopdracht en het Hof wijst de vordering af wegens het ontbreken van causaal verband. Volgens de Hoge Raad geeft dit geen blijk van een onjuiste rechtsopvatting.

Het hof beoordeelt het causaal verband door de situatie zoals die zich heeft voorgedaan te vergelijken met de situatie waarin het bedrijf had verkeerd als de Gemeente hem direct niet-ontvankelijk had verklaard en aan het bedrijf vervolgens door Gedeputeerde Staten een vergunning ingevolge de Afvalstoffenwet was verleend. Het condicio sine qua non verband ontbreekt indien in plaats van het onrechtmatige besluit, de onrechtmatigheid weggedacht, een rechtmatig besluit zou zijn genomen dat dezelfde schade tot gevolg zou hebben gehad.

Recent sloot het Gerechtshof Amsterdam echter wel aan bij het causaliteitscriterium van de Afdeling. Het ging om een zaak waarin twee ontslagen bestuurders van een N.V. schadeclaims tegen De Nederlandsche Bank en Autoriteit Financiële Markten hebben ingediend. Volgens de ex-bestuurders leidden besluiten van de DNB en AFM ertoe dat zij als bestuurder zijn ontslagen. De betreffende besluiten zijn door het College van Beroep voor het bedrijfsleven vernietigd wegens een motiveringsgebrek. Het CBb heeft AFM en DNB de mogelijkheid geboden om rechtmatige besluiten te nemen, maar zij zijn daarin niet geslaagd. Het $\mathrm{CBb}$ heeft hen vervolgens geen nieuwe kans gegeven, maar heeft zelf de aanwijzingen herroepen. Tegen deze achtergrond oordeelt het hof dat het niet direct voor de hand ligt ervan uit te gaan dat een mogelijkheid bestond om dezelfde beslissingen maar dan met een deugdelijke motivering te nemen. Het hof overweegt met betrekking tot het causaliteitscriterium:

\footnotetext{
"Eerst zal, nu het CBB heeft geoordeeld dat de beide besluiten lijden aan een motiveringsgebrek, onderzocht worden of, zoals AFM en DNB betogen, ten tijde van het nemen van de rechtens onjuiste besluiten rechtmatige besluiten zouden hebben kunnen worden genomen, die naar aard en omvang eenzelfde schade tot gevolg zouden hebben gehad."31
}

Het lijkt mij overigens niet dat het causaliteitscriterium van de Afdeling meebrengt dat ook geen recht op vergoeding van vertragingsschade bestaat, die wordt veroorzaakt door een formele vernietiging waarna een inhoudelijk gelijk besluit tot stand komt.

Stel dat een bouwvergunning wordt verleend. Derden belanghebbenden vechten deze vergunning aan en de bestuursrechter vernietigt de vergunning vanwege een formeel gebrek. Na reparatie van dit gebrek wordt alsnog een rechtmatige bouwvergunning afgegeven en kan de geadresseerde aanvangen met de bouw. ${ }^{\mathbf{2}}$ In de tussentijd kan de bouwer echter vertragingsschade hebben geleden. Op zich had in dit geval direct een rechtmatig besluit kunnen worden genomen. Het is alleen niet gebeurd en juist daardoor is schade geleden. Oftewel: als ten tijde 
van het rechtens onjuiste besluit een rechtmatig besluit zou zijn genomen, dan zou geen vertragingsschade zijn geleden. Het gaat daarom naar mijn mening niet om een situatie dat in plaats van het onrechtmatige besluit een rechtmatig besluit had kunnen worden genomen dat naar aard en omvang dezelfde schade tot gevolg zou hebben gehad.33

Er is (mij) geen jurisprudentie van de Centrale Raad van Beroep en het College van Beroep voor het bedrijfsleven bekend waarin het - afwijkende - criterium van de Afdeling door deze rechtscolleges wordt overgenomen.

\subsubsection{Literatuur}

Kortmann signaleert dat het causaliteitsvereiste van de Afdeling afwijkt van het vereiste van condicio sine qua non. ${ }^{\mathbf{3 4}}$ Toepassing van het condicio sine qua non vereiste zou volgens Kortmann meebrengen dat voor aansprakelijkheid niet alleen een rechtmatig besluit zou hebben kunnen worden genomen, maar ook daadwerkelijk zou zijn genomen. Hij gaat ervan uit dat het een bewuste keuze is van de Afdeling om op dit punt af te wijken van de condicio sine qua non toets. Hij geeft aan dat de leer die de Afdeling hanteert in Duitsland bekend staat als het rechtmäßiges Alternativverhalten en benadrukt dat deze leer daar niet is aanvaard als causaliteitsleer en in ons land evenmin. ${ }^{35}$ Zelf is Kortmann ook geen voorstander van deze leer. Hij illustreert dit door middel van een zaak over het inmiddels gewijzigde ruimtelijk ordeningsrecht, waarin een bouwvergunning wordt vernietigd wegens strijd met het bestemmingsplan. B\&W steunden het bouwplan niet en zouden dus geen medewerking hebben verleend aan een vrijstelling ex artikel 19 (oud) WRO. Hij vraagt zich af of de gemeente zich in dat geval toch tegen een schadeclaim van omwonenden kan verweren met het argument dat B\&W ook een rechtmatige vergunning had kunnen verlenen, namelijk met een artikel 19 lid 2 (oud) WRO vrijstelling? Kortmann stelt dat volgens de betreffende Afdelingsuitspraken inderdaad de conclusie zou zijn dat causaal verband ontbreekt, omdat een rechtmatig besluit genomen had kunnen worden. Toepassing van het condicio sine qua non vereiste geeft volgens hem echter een ander resultaat: een dergelijk besluit zou nooit zijn genomen nu vast staat dat B\&W geen medewerking zouden hebben verleend aan een vrijstelling. De 'echte' condicio sine qua non toets appelleert naar de mening van Kortmann meer aan het rechtvaardigheidsgevoel. Ook doet het recht aan een van de grondbeginselen van het onrechtmatigedaadsrecht: het beginsel van restitutio in intergrem. Dit houdt in dat de benadeelde zoveel mogelijk in de positie moet worden gebracht als ware de onrechtmatige daad niet gepleegd. Hij wijst erop dat als B\&W het bestemmingsplan juist hadden uitgelegd, de bouwvergunning niet zou zijn verleend. De schade komt dus zijns inziens voor vergoeding in aanmerking. Kortmann concludeert dan ook dat de Afdeling de obscure leer van het rechtmäßiges Alternativverhalten weer moet verruilen voor de echte condicio sine qua non toets. De rechter moet zich dan afvragen hoe het onrechtmatige besluit zou hebben geluid als de normschending, die tot de onrechtmatigheid leidde, niet zou hebben plaatsgevonden. Hij wijst er nog op dat deze vraag zowel een juridisch aspect (welk besluit had kunnen worden genomen?) als een feitelijk aspect (welk besluit zou binnen de grenzen van rechtmatigheid daadwerkelijk zijn genomen?) heeft.

Schlössels ziet als belangrijk praktisch probleem bij de benadering van Kortmann dat het in veel gevallen moeilijk is om vast te stellen hoe een 
rechtmatig besluit zou hebben geluid, zeker als sprake is van beleidsvrijheid. ${ }^{\mathbf{6}}$ In dat kader wijst hij op de suggestie van Akkermans om, indien onzekerheid blijft bestaan over de inhoud van een hypothetisch rechtmatige situatie, moet worden aanvaard dat de rechter een gedeeltelijke schadevergoeding kan toekennen waarvan de omvang in beginsel wordt bepaald door de mate van waarschijnlijkheid dat de gedraging tot de gestelde schade heeft geleid. ${ }^{37}$ Als ik het goed begrijp stelt Schlössels voor deze situatie dus een proportionele aansprakelijkheid van het bestuursorgaan voor. ${ }^{\mathbf{8}}$

Tak meent dat door de besproken causaliteitsredenering vastgestelde onrechtmatigheden aldus worden 'gerechtvaardigd' als ook rechtmatig gehandeld had kunnen worden. Hij is van mening dat deze 'speculatie, via een retrospectieve, puur fictieve en door partijen niet te bestrijden statement niet kan dienen als surrogaat voor een condicio sine qua non vereiste'. Tak zou eenvoudig de rekening voor alle werkelijk ingetreden gevolgen leggen op het bordje van de overheid, die het in haar vermogen had om, door te doen wat zij behoorde te doen, alle schade te voorkomen.39

Volgens Berkel-Kikkert en Broekhuizen is het onduidelijk of het bestuursorgaan op grond van de betreffende uitspraken mag volstaan met het aannemelijk maken dat een rechtmatig besluit in theorie zou hebben kunnen worden genomen of dat aannemelijk moet worden gemaakt dat dit besluit ook daadwerkelijk zou zijn genomen. ${ }^{40} \mathrm{Zij}$ menen het laatste, omdat het condicio sine qua non verband een feitelijk verband is.

\subsubsection{Beoordeling en conclusie}

Geconstateerd wordt dat het causaliteitscriterium dat bij besluitenaansprakelijkheid geen causaal verband bestaat, indien in plaats van het onrechtmatige besluit een rechtmatig besluit had kunnen worden genomen dat dezelfde schade had veroorzaakt, afwijkt van het condicio sine qua non vereiste. Bij toepassing van het condicio sine qua non criterium zou het erom gaan dat ook daadwerkelijk een rechtmatig besluit zou zijn genomen.

Het verschil komt erop neer dat het causaal verband tussen het onrechtmatige besluit en de schade ontbreekt als het bestuursorgaan weliswaar een rechtmatig besluit had kunnen nemen dat dezelfde schade zou hebben veroorzaakt, maar dit in werkelijkheid niet zou hebben gedaan en er dus geen schade zou zijn geleden. In dat opzicht zit er (wat) ruimte tussen de beide criteria.

De rechter geeft zelf niet aan waarom hij in dit opzicht afwijkt van het condicio sine qua non vereiste. Een reden hiervoor zou kunnen zijn dat het, zoals Schlössels aangeeft, over het algemeen erg lastig is om te achterhalen welk besluit daadwerkelijk zou zijn genomen indien de onrechtmatigheid wordt weggedacht. Dit maakt dat het bij besluitenaansprakelijkheid lastig kan zijn om de 'klassieke' condicio sine qua non leer toe te passen indien er meerdere rechtmatige opties bestaan. Deze omstandigheid is kenmerkend voor het besluitenaansprakelijkheidsrecht. Bij onrechtmatig feitelijk handelen is het vaak makkelijker om te reconstrueren wat er zou zijn gebeurd als de onrechtmatige daad wordt weggedacht.

Als de bestaande beleidsvrijheid is ingevuld door duidelijke beleidsregels kan de uitkomst van de besluitvormingsprocedure wellicht nog met enige zekerheid worden vastgesteld. Dit zal echter niet altijd het geval zijn. Genoemde bewijsproblemen worden ondervangen door het criterium van de Afdeling. Het 
is nu eenmaal makkelijker om vast te kunnen stellen dat een rechtmatig besluit - juridisch - had kunnen worden genomen, dan te achterhalen wat er - feitelijk - gebeurd zou zijn als het bestuursorgaan niet onrechtmatig zou hebben gehandeld.

Ik vraag mij af in hoeverre dit onderscheid in de praktijk zal leiden tot verschillende uitkomsten met betrekking tot het causaal verband. Het zal immers meestal gaan om besluiten, die - de formele vernietigingsgrond weggedacht - tot hetzelfde inhoudelijke besluit hadden kunnen leiden. Indien een bestuursorgaan een rechtmatig besluit met dezelfde inhoud had kunnen nemen, komt het mij voor dat hij dit vaak ook wel gedaan zou hebben. Hij heeft immers ook daadwerkelijk een dergelijk besluit genomen, zij het één met een formeel gebrek.

Aan de andere kant bestaan er natuurlijk wel situaties dat het bestuursorgaan in eerste instantie liever een andersluidend besluit had willen nemen, maar ten onrechte dacht dat dit niet mogelijk was, bijvoorbeeld omdat hij uitging van onjuiste feiten (en het onrechtmatige besluit dus leed aan een motiveringsgebrek). Indien in dat geval meerdere rechtmatige opties bestonden had een gelijkluidend rechtmatig besluit misschien wel kunnen worden genomen, maar was dit in werkelijkheid niet gebeurd als het bestuursorgaan direct rechtmatig had gehandeld. Nog ingewikkelder wordt het als slechts een rechtmatig besluit, dat dezelfde schade tot gevolg zou hebben gehad als het onrechtmatige besluit, had kunnen worden genomen nadat bepaalde procedurele stappen (zouden) zijn gezet. ${ }^{\mathbf{4 1}}$

Feit blijft dat het genoemde criterium materieel verschilt van het condicio sine qua non vereiste bij feitelijke handelingen. Dit kan er toe leiden dat een schadeclaim wordt afgewezen wegens het ontbreken van causaal verband terwijl de schade niet zou zijn geleden als het bestuursorgaan direct rechtmatig had gehandeld. Genoemd onderscheid manifesteert zich het meest zichtbaar in zaken waarin meerder rechtmatige opties bestaan en aannemelijk gemaakt kan worden dat het bestuursorgaan weliswaar een rechtmatig besluit had kunnen nemen, maar dit in werkelijkheid nooit zou hebben gedaan.

Alles afwegende denk ik dat de duidelijkheid die het afwijkende causaliteitscriterium van de Afdeling biedt de doorslag moet geven. Op deze manier worden veel bewijsproblemen voorkomen. Dit is ook in het voordeel van de benadeelde. Onduidelijkheid over de feitelijke situatie leidt meestal tot eindeloze procedures met een onzekere uitkomst. Daarbij komt dat in de praktijk het verschil tussen de beide criteria mijns inziens niet erg groot zal zijn. Deze redenen vormen naar mijn mening voldoende rechtvaardiging om bij besluitenaansprakelijkheid op dit punt af te wijken van de causaliteitsleer, zoals die wordt toegepast bij feitelijke handelingen.

\subsection{Onderbroken causaliteit en de invloed van verlengde besluitvorming op het causaal verband}

\subsubsection{Inleiding}

Kenmerkend voor besluitenaansprakelijkheid is dat na vernietiging van het besluit vaak verlengde besluitvorming plaatsvindt die, als het goed is, resulteert in een rechtmatig besluit. Deze paragraaf bespreekt de invloed van de verlengde besluitvorming op het causaal verband en maakt een vergelijking met de 
jurisprudentie over 'onderbroken causaliteit'.

\subsubsection{Onderbroken (meervoudige) causaliteit: algemeen}

Indien zich na een schadeveroorzakende gebeurtenis, waarvoor iemand aansprakelijk is jegens de benadeelde, een latere gebeurtenis voordoet die dezelfde schade zou hebben veroorzaakt als die schade niet reeds was ontstaan, doet dat niet af aan de reeds gevestigde verplichting tot schadevergoeding van de voor de eerste gebeurtenis aansprakelijke. ${ }^{\mathbf{4 2}}$ Dit geldt ook voor schade, die nog wordt geleden nadat de tweede gebeurtenis heeft plaatsgevonden (zgn. voortdurende schade), in ieder geval als een derde aansprakelijk is voor de latere schadeoorzaak. Indien de tweede gebeurtenis voor eigen rekening van de benadeelde komt wordt de schade die hierna wordt geleden wel toegerekend aan deze tweede gebeurtenis. ${ }^{43}$ Een omstandigheid, die voor eigen risico komt, is bijvoorbeeld een ziekte, die niet door de onrechtmatige daad is veroorzaakt en waaraan derden geen schuld hebben. $\mathbf{4 4}$

\subsubsection{Rechtspraak}

Uit het eerder besproken causaliteitscriterium van de Afdeling bestuursrechtspraak van de Raad van State volgt dat volgens haar het antwoord op de vraag of sprake is van causaal verband in principe niet afhankelijk is van de uitkomst van de verlengde besluitvormingsprocedure: bepalend is of al dan niet een rechtmatig besluit 'had kunnen worden genomen' dat dezelfde schade tot gevolg zou hebben gehad als het onrechtmatige besluit. ${ }^{45}$ De uitkomst van de verlengde besluitvormingsprocedure speelt overigens wel een belangrijke rol bij het bewijs van causaal verband. Dit zal in paragraaf 5.3.2. aan de orde komen. Het is dus inherent aan het door de Afdeling gehanteerde causaliteitscriterium, dat zij bij de bepaling van het causaal verband abstraheert van het toekomstige rechtmatige besluit.

In sommige gevallen had het bestuursorgaan pas een rechtmatig besluit met hetzelfde rechtsgevolg kunnen nemen nadat bepaalde procedurele stappen zouden zijn gevolgd, zoals bijvoorbeeld de wijziging van een bestemmingsplan. Deze situaties zullen zich naar mijn mening met name voordoen in het ruimtelijke ordeningsrecht. Dit was ook aan de orde in de zaken, die hebben geleid tot de besproken uitspraken van 15 december 2004. De Afdeling overweegt:

\footnotetext{
"Indien tussen het moment van het nemen van het rechtens onjuiste besluit en dat, waarop een rechtmatig besluit zou hebben kunnen worden genomen tijd ligt, omdat - zoals in dit geval - voor het nemen van het rechtmatige besluit bepaalde procedurele stappen moesten of zouden moeten worden genomen, kan schade die gedurende deze periode wordt geleden, worden toegerekend aan het rechtens onjuist bevonden besluit en komt deze in beginsel voor vergoeding in aanmerking." 46
}

In de zaak tegen de gemeenteraad van Meerssen was het zo dat deze bij besluit van 28 mei 1998 een vrijstelling op grond van artikel 19 WRO (oud) hadden verleend ten behoeve van de aanleg van een weg. De Afdeling oordeelde op 1 mei 2000 dat deze vrijstelling onrechtmatig was. Vervolgens is het streekplan 
gewijzigd en kon op 17 januari 2002 alsnog een rechtmatige vrijstelling worden verleend. Gelaedeerde stelt door het onrechtmatige besluit schade te hebben geleden, bestaande uit waardevermindering van haar woning en genotsderving. De gemeente wijst haar verzoek tot schadevergoeding af. De Afdeling:

"In elk geval is van aansprakelijkheid van de raad voor schade, geleden na 17 januari 2002, geen sprake."

In de Amelandse zaak ging het om een op 14 april 1992 verleende bouwvergunning voor een benzinestation. Een concurrerend benzinestationhouder kwam hiertegen op. De Afdeling oordeelde op 1 maart 1996 dat deze bouwvergunning onrechtmatig was wegens strijd met het bestemmingsplan. Bij besluit van 28 oktober 1997 werd wederom een bouwvergunning verleend door vrijstelling van het bestemmingsplan. Deze vergunning is gehandhaafd op bezwaar op 12 maart 2002. Dit laatste besluit werd gebaseerd op het nieuwe, inmiddels vastgestelde (maar nog niet in werking ingetreden) bestemmingsplan. Het benzinestation was in overeenstemming met dit plan. De Afdeling oordeelde dat ten tijde van de beslissing op bezwaar aan de formele vereisten voor de vrijstelling was voldaan en deze derhalve verleend mocht worden. De concurrerende benzinestationhouder wil vergoeding wegens winstderving geleden van 14 april 1992 tot aan de verkoop van zijn onderneming in november 2001. Volgens de rechtbank staat voldoende vast dat een oorzakelijk verband bestaat tussen het omzetverlies in de jaren 1992 tot en met 1997 en vestiging en exploitatie van het benzinestation. De Afdeling laat dit oordeel in stand. De Afdeling:

"In elk geval is [...] van aansprakelijkheid van het college voor schade, geleden na 28 oktober 1997, geen sprake.

De Afdeling rekent dus aan het onrechtmatige besluit toe schade, die is geleden totdat een rechtmatig besluit had kunnen worden genomen. De Afdeling is van oordeel dat een zekere objectivering van de tijdsduur noodzakelijk is. Het college van $B \& W$ van Ameland had zich op het standpunt gesteld dat de vrijstellingsprocedure in dit geval ongeveer anderhalf jaar zou hebben geduurd. Dit komt de Afdeling reëel en redelijk voor. De periode waarover schadevergoeding dient te worden betaald loopt daarom volgens de Afdeling vanaf het nemen van het onrechtmatige besluit tot anderhalf jaar daarna: concreet van 14 april 1992 tot 15 oktober 1993. In werkelijkheid was uiteindelijk op 1 augustus 2006 pas een legaliserend besluit genomen. Het causaliteitscriterium van de Afdeling brengt echter mee dat geen recht bestaat op vergoeding van schade geleden vanaf het moment dat een rechtmatig besluit had kunnen worden genomen. 47

Ik vraag mij af of en zo ja, hoe het bestuursorgaan deze termijn van anderhalf jaar onderbouwd heeft. Dit blijkt niet uit de uitspraak. Het lijkt mij zeer lastig om te reconstrueren wanneer daadwerkelijk de benodigde wijzigingen hadden kunnen doorgevoerd als het bestuursorgaan de noodzaak daarvan direct bij aanvang van de besluitvorming had ingezien en vervolgens een rechtmatig besluit had kunnen nemen.

Volgens de Afdeling gaat het wel om een objectivering van de werkelijke termijn, maar dit betekent blijkens de uitspraak een schatting van de reële termijn. $\mathrm{Nu}$ 
het bestuursorgaan er belang bij heeft om deze termijn zo kort mogelijk voor te spiegelen, lijkt mij een nadere motivering daarvan op zijn plaats. In ieder geval moet naar mijn mening wel discussie kunnen bestaan over de lengte van de termijn.

Door de betreffende jurisprudentie wordt een eenmaal gevestigd causaal verband met een onrechtmatig besluit doorbroken op het moment dat een rechtmatig besluit had kunnen worden genomen. In dit kader zou zich de vraag kunnen opdringen hoe deze rechtspraak zich verhoudt tot de regel dat toekomstige gebeurtenissen niet afdoen aan een reeds gevestigde verplichting tot vergoeding van schade, inclusief voortdurende schade, tenzij deze voor rekening van de benadeelde komt. ${ }^{48}$ Ik denk echter dat een dergelijke vergelijking spaak loopt. Het afwijkende causaliteitscriterium van de Afdeling brengt immers mee dat het - in tegenstelling tot de betreffende civiele jurisprudentie - niet gaat om een daadwerkelijke gebeurtenis, maar om een fictief moment. Daarnaast meen ik dat de situatie van een legaliserend besluit in het algemeen niet vergeleken kan worden met het leerstuk over het doorbroken causaal verband. Een legaliserend besluit is naar mijn mening van een andere orde dan de 'toekomstige gebeurtenis' uit de betreffende rechtspraak. In de uitspraken over doorbroken causaal verband veroorzaakt een feitelijke onrechtmatige handeling schade, waarna een gebeurtenis van geheel andere aard dezelfde schade veroorzaakt, dan wel zou hebben veroorzaakt. Hierbij kan de tweede gebeurtenis worden onderverdeeld in twee 'categorieën'. Ten eerste de toekomstige gebeurtenis waarvoor een derde aansprakelijk is, zoals het stichten van een brand, en die het gevestigde causaal verband niet doorbreekt. Ten tweede een omstandigheid die bij de benadeelde ligt, zoals een ziekte, en die daarom voor zijn rekening komt. In de aangehaalde zaak van Los/Leeuwarden bijvoorbeeld had de benadeelde schade geleden doordat de gemeente Leeuwarden aan hem onrechtmatig de huur van een aantal horecaruimten had opgezegd. Vervolgens steken derden het complex waar deze ruimten deel van uitmaakten in brand waardoor het vergaat. De Hoge Raad oordeelt dat de brand niet afdoet aan de reeds gevestigde verplichting tot schadevergoeding van de gemeente, ook niet voor duurschade die nog na de brand wordt geleden. ${ }^{49} \mathrm{De}$ 'onderbrekende' gebeurtenis van een gelijkluidend rechtmatig besluit is van een geheel andere aard. In dat geval is de tweede gebeurtenis de neerslag van de reparatie van de onrechtmatigheid. Door een legaliserend besluit blijkt dat de schadeveroorzakende situatie, die aanvankelijk onjuist tot stand was gekomen, toch binnen het recht past. $\mathbf{5 0}^{\mathbf{o}}$

Ook andere toekomstige omstandigheden dan de verlengde besluitvorming kunnen een rol spelen bij het causaliteitsoordeel inzake schadevergoeding voor vernietigde besluiten. In paragraaf 5.1.2. wordt besproken de uitspraak waarin twee ontslagen bestuurders van een N.V. schadeclaims tegen De Nederlandsche Bank en Autoriteit Financiële Markten hebben ingediend. Ook in deze zaak spelen met betrekking tot het vaststellen van causaal verband toekomstige gebeurtenissen een rol. De ex-bestuurders zijn namelijk ook door de strafrechter veroordeeld wegens overtreding van de Wte. Het hof neemt aan deze latere gebeurtenis ook tot hun ontslag zouden hebben geleid en oordeelt op grond daarvan dat de AFM en DNB niet aansprakelijk zijn voor schade geleden na de datum van de belastende vonnissen. De strafvonnissen leiden tot een onderbreking van het eerder gevestigde causaal verband, omdat de veroordelende vonnissen voor rekening moeten komen van de benadeelden. De 
Hoge Raad bevestigt dit. ${ }^{\mathbf{1}}$ Dit is in overeenstemming met jurisprudentie over onderbroken causaal verband tussen civiele partijen..$^{\mathbf{2}}$

\subsubsection{Literatuur}

In minder recente literatuur is wel betoogd dat de uitkomst van de verlengde besluitvormingsprocedure van belang is bij de bepaling van het causaal verband.53

Tegenwoordig overheerst in de literatuur de opvatting dat de uitkomst van de verlengde besluitvormingsprocedure geen invloed zou moeten hebben op de vraag of causaal verband bestaat tussen de schade en het onrechtmatige besluit. Hiervoor worden verschillende argumenten aangevoerd.

Ten eerste zou het een afwijking van het civiele recht betekenen om het vaststellen van causaal verband afhankelijk te stellen van toekomstige omstandigheden. $\mathbf{5 4}$

Ten tweede wordt deze benadering onaantrekkelijk gevonden, omdat het er toe kan leiden dat het bestuursorgaan in de verlengde besluitvormingsprocedure koste wat kost het oorspronkelijk besluit overeind probeert te houden om aansprakelijkheid te voorkomen.55 Een inhoudelijk gelijkluidend rechtmatig besluit zou immers meebrengen dat geen causaal verband bestaat tussen het onrechtmatige besluit en de schade.

Ten derde brengt het veel rechtsonzekerheid met zich mee voor de gelaedeerde. Hij moet immers afwachten tot de verlengde besluitvorming is afgerond, voordat hij duidelijkheid kan krijgen over de gegrondheid van zijn schadeclaim.56 Ten slotte wordt aangevoerd dat de gelaedeerde, die slechts zijn schade vergoed wil zien, inhoudelijk door zou moeten procederen tegen het besluit alleen om zijn belangen met betrekking tot de schadevergoeding veilig te stellen. ${ }^{\mathbf{5 7}} \mathrm{Om}$ causaal verband aannemelijk te maken dient hij te bewerkstelligen dat een inhoudelijk andersluidend besluit tot stand komt. Dit leidt tot extra procedeerdwang. Vooral bij besluiten, waarin het bestuursorgaan reparatie- en legalisatiepogingen mag stapelen, zou het bijna onmogelijk zijn om causaal verband te kunnen aantonen..$^{8}$

Kortmann wijst erop dat ten tijde van de verlengde besluitvorming de omstandigheden sinds het nemen van het oorspronkelijk besluit aanzienlijk veranderd kunnen zijn. Dit kan volgens hem aanleiding zijn voor een nieuwe afweging met een andere uitkomst dan het onrechtmatige besluit of voor eenzelfde uitkomst maar met andere redenen. Om dan op basis van het nieuwe, rechtmatige besluit al dan geen causaal verband aan te nemen tussen de schade en het onrechtmatige besluit acht hij in strijd met het uitgangspunt van restitutio in intergrem (het volgens hem algemeen aanvaarde beginsel dat de benadeelde zoveel mogelijk in de positie moet worden gebracht, als ware een rechtmatig besluit genomen), omdat het uiteindelijke besluit een andere achtergrond, uitkomst en rechtsgevolg heeft dan het besluit dat zou zijn genomen als in eerste instantie rechtmatig zou zijn beslist. 59 De opvatting van Kortmann is dat niet de uitkomst van de verlengde besluitvormingsprocedure bepalend dient te zijn bij het vaststellen van causaal verband, maar het hypothetisch rechtmatige besluit. Dat houdt in dat de overheid alleen die schade niet hoeft te vergoeden, die ook zou zijn ingetreden als (onder overigens gelijkblijvende omstandigheden) een rechtmatig besluit was genomen. Deze retrospectieve vergelijking sluit zijns inziens beter aan bij de civielrechtelijke 
bepaling van het causaal verband en neemt de genoemde bezwaren tegen de invloed van de verlengde besluitvormingsprocedure op de beoordeling van het causaal verband weg. Het criterium van het hypothetisch rechtmatige besluit doet naar de mening van Kortmann ook recht aan de gedachte van de wetgever, dat bij toepassing van artikel 8:73 Awb causaal verband moet bestaan tussen de schade en de vernietigingsgrond ${ }^{\mathbf{6 0}}$, omdat het dictum van het besluit dat had moeten worden genomen verband houdt met de reden waarom het daadwerkelijk genomen besluit wordt vernietigd. ${ }^{61}$

Volgens Schlössels lijkt de 'verlengde' oorzakelijkheidsbenadering niet bezwaarlijk voor zover in het kader van de verlengde besluitvorming alsnog een rechtmatig besluit tot stand komt met exact hetzelfde dictum als het vernietigde besluit. Anders ligt het volgens hem als het dictum van het reparatiebesluit niet gelijk is aan het onrechtmatige besluit. Hij noemt als voorbeeld de situatie dat eerst onterecht een bouwvergunning wordt geweigerd en daarna op juiste gronden alsnog wordt verleend. Schlössels meent dat in deze situatie niet kan worden volgehouden dat de bestuurlijke besluitvorming niet als oorzaak van de schade kan gelden, omdat er uiteindelijk een rechtmatig besluit tot stand is gekomen. Het is naar zijn mening immers zeer goed mogelijk dat het onrechtmatige besluit al schade heeft veroorzaakt. Vanuit theoretisch oogpunt is het zijns inziens dan ook zuiverder om met het oog op de causaliteitstoets aansluiting te zoeken bij het (onrechtmatige) primaire besluit: zodra dit besluit tot stand is gekomen kan het immers terstond gelden als schadeoorzaak.

Hieraan doet volgens Schlössels niet af dat de eventuele onrechtmatigheid van dit besluit eerst achteraf in het kader van een vernietiging van het heroverwegingsbesluit aan het daglicht treedt. ${ }^{62}$

Schlössels meent dat het aannemen van causaal verband niet afhankelijk mag worden gesteld van de uitkomst van de verlengde besluitvormingsprocedure, omdat rechtmatige toekomstige besluiten schade die reeds is ontstaan tengevolge van een onrechtmatige besluiten logischerwijs niet meer ongedaan kunnen maken. Hij wijst erop dat het vernietigde besluit als rechtsfeit blijft bestaan, ook al is de rechtshandeling met inbegrip van de beoogde rechtsgevolgen als zodanig ex tunc uit de rechtsorde verwijderd. Het feit dat dit besluit nu eenmaal is genomen, kan volgens hem simpelweg niet meer ongedaan worden gemaakt. ${ }^{63}$ Tak wijst er volgens Schlössels terecht op dat de 'nieuwe' beslissing op bezwaar na vernietiging in beginsel slechts ex nunc werkt. ${ }^{64}$ Tak geeft aan dat pas vanaf het moment dat een rechtmatige beslissing op bezwaar is genomen is er sprake van een rechtmatig besluit en niet eerder. Hij stelt dat voor dat moment nooit sprake is geweest van een rechtmatig geldig overheidsbesluit waardoor bepaalde gevolgen zouden kunnen zijn ingetreden die van dezelfde soort zijn als de nieuwe, rechtmatige beslissing op bezwaar. Misschien had het wel gekund, maar het is niet gebeurd. ${ }^{65}$ Ook is Tak van mening dat een nieuwe beslissing op bezwaar geen rol zou mogen spelen bij het bepalen van causaal verband, omdat er bij verlengde besluitvorming een effect van 'fait accompli' optreedt: als eenmaal het beton is gestort worden plannen volgens hem daarop nu eenmaal aangepast. ${ }^{\mathbf{6 6}}$ Ook het causaliteitscriterium van de Afdeling biedt overigens geen ruimte voor het argument dat zonder het onrechtmatige besluit er nooit een rechtmatig (reparatie)besluit zou zijn genomen, omdat het erom gaat of een rechtmatig besluit had kunnen worden genomen dat dezelfde schade zou hebben veroorzaakt en niet of dit ook daadwerkelijk gebeurd zou zijn. ${ }^{67}$ 


\subsubsection{Beoordeling en conclusie}

In de literatuur overheerst de opvatting dat (de uitkomst van) de verlengde besluitvormingsprocedure geen invloed zou moeten hebben op de vraag of causaal verband bestaat tussen de schade en het onrechtmatige besluit. Ook het causaliteitscriterium van de Afdeling abstraheert in principe van de uitkomst van de verlengde besluitvormingsprocedure, omdat het erom gaat of een rechtmatig besluit had kunnen worden genomen dat dezelfde schade tot gevolg zou hebben gehad als het onrechtmatige besluit.

De Afdeling legt haar causaliteitscriterium zo uit, dat geen causaal verband meer bestaat vanaf het moment dat een rechtmatig besluit had kunnen worden genomen. Een vergelijking in dit kader tussen deze situatie en het leerstuk van het onderbroken causaal verband lijkt mij niet goed mogelijk en ook weinig zinvol. Bij besluitenaansprakelijkheid gaat het immers niet om een daadwerkelijke gebeurtenis, maar om een fictief moment. Bovendien is verlengde besluitvorming naar mijn mening van geheel andere aard dan de toekomstige gebeurtenissen uit de civiele rechtspraak over het doorbreken van causaal verband.

Over de invloed van andere gebeurtenissen dan verlengde besluitvorming op het causaal verband bestaat weinig rechtspraak. De besproken uitspraak over aansprakelijkheid van DNB en AFM is in ieder geval in overeenstemming met de regel dat eenmaal gevestigd causaal verband kan worden doorbroken indien de tweede (toekomstige) gebeurtenis voor rekening komt van de benadeelde.

\subsection{Bewijs van condicio sine qua non verband}

\subsubsection{Bewijs van condicio sine qua non verband: algemeen}

Het procesrechtelijke onderwerp van het bewijsrecht speelt in de praktijk een belangrijke rol bij de vaststelling van causaal verband. Of het bestaan van een causaal verband kan worden aangetoond, bepaalt in belangrijke mate de kans op toe- dan wel afwijzing van de vordering.

Artikel 150 Wetboek van Burgerlijke Rechtsvordering bepaalt dat de partij die zich beroept op rechtsgevolgen van door haar gestelde feiten of rechten daarvan de bewijslast draagt, tenzij uit enige bijzondere regel of uit de eisen van redelijkheid en billijkheid een andere verdeling van de bewijslast voortvloeit. Doorgaans zal de bewijslast van het condicio sine qua non verband op grond van deze hoofdregel van bewijsrecht dus rusten op degene, die schadevergoeding vordert.

Met betrekking tot het bewijs van het condicio sine qua non verband wordt geen absolute zekerheid geëist. Een redelijke mate van waarschijnlijkheid dat de schade wel/niet zou zijn ingetreden zonder de onrechtmatige gebeurtenis is voldoende. ${ }^{68}$

Door wet en jurisprudentie worden uitzonderingen gemaakt op de hoofdregel dat eiser(es) moet stellen en bij voldoende gemotiveerde betwisting dient te bewijzen dat causaal verband bestaat tussen de onrechtmatige daad en de schade. Een paar belangrijke uitzonderingen zullen hierna worden besproken. Ten eerste ziet artikel 6:99 BW op de situatie dat de schade het gevolg kan zijn van twee of meer gebeurtenissen voor elk waarvan een andere persoon aansprakelijk is en vast staat dat de schade door ten minste één van deze 
gebeurtenissen is ontstaan. In dat geval rust de verplichting om schade te vergoeden op ieder van deze personen, tenzij hij bewijst dat deze niet het gevolg is van een gebeurtenis waarvoor hij zelf aansprakelijk is. In een dergelijk geval achtte de wetgever het onbillijk om de benadeelde zelf zijn schade te laten dragen, omdat hij niet kan bewijzen door welke van de verschillende handelingen zijn schade is veroorzaakt. ${ }^{69}$

Ten tweede maakt ook de 'omkeringsregel' een uitzondering op de hoofdregel 'wie stelt, bewijst' met betrekking tot het condicio sine qua non verband. Deze regel is ontwikkeld in de jurisprudentie en houdt in dat het condicio sine qua non verband tussen de schade en de onrechtmatige gedraging in beginsel gegeven is. Het is aan de gedaagde om te stellen en te bewijzen dat die schade ook zonder de onrechtmatige gebeurtenis zou zijn ingetreden. ${ }^{\mathbf{7 0}}$ Voldoende voor dit tegenbewijs is dat de gedaagde aannemelijk maakt dat de schade ook zonder die gedraging zou zijn ontstaan. Toepassing van de omkeringsregel is aan de orde als het gaat om schending van een norm die ertoe strekt een specifiek gevaar ter zake van het ontstaan van schade bij een ander te voorkomen en als dit gevaar door de normschending in het algemeen aanmerkelijk wordt vergroot. Voor toepassing van de omkeringsregel dient de eiser aannemelijk te maken dat in het concrete geval het (specifieke) gevaar waartegen de norm bescherming beoogt te bieden zich heeft verwezenlijkt. ${ }^{71}$ De ratio van de omkeringsregel wordt door de Hoge Raad als volgt verwoord:

"In dat geval is het immers, gelet op de bescherming die een dergelijke norm beoogt te bieden, redelijk, behoudens tegenbewijs, ervan uit te gaan dat, als het specifieke gevaar waartegen de norm beoogt te beschermen, zich heeft verwezenlijkt, zulks een gevolg moet zijn geweest van deze normschending."72

De omkeringsregel is dus een uitzondering op de hoofdregel van artikel 150 Wetboek van Burgerlijke Rechtsvordering die is gebaseerd op de redelijkheid en billijkheid. Over het feitelijke toepassingsbereik van de omkeringsregel lijkt niet altijd eenduidigheid te bestaan en deze heeft in de loop van de tijd ook gevarieerd. ${ }^{73}$ Momenteel wordt aangenomen dat de omkeringsregel (vooral) geldt bij schending van verkeers- en veiligheidsnormen. ${ }^{\mathbf{7 4}}$

Ten slotte kan de rechter in individuele zaken afwijken van de hoofdregel. Het gaat er dan meestal om dat hij het bestaan van een condicio sine qua non verband, behoudens tegenbewijs, aanneemt. Hij doet dit bijvoorbeeld omdat de kans dat de schade zich zonder de onrechtmatige daad niet zou hebben voorgedaan zo aanzienlijk is, dat ervan kan worden uitgegaan dat sprake is van een condicio sine qua non verband. ${ }^{75}$ Ook neemt hij aanwezigheid van het condicio sine qua non verband soms als uitgangspunt indien in de betreffende zaak het bewijs ervan problematisch is. ${ }^{\mathbf{6}}$

\subsubsection{Bewijs van condicio sine qua non verband bij besluitenaansprakelijkheid}

In het algemeen kan worden gezegd dat het theoretische verschil tussen het civiele en bestuursrechtelijke bewijsrecht aanzienlijk is. Het civiele recht kent strikte, wettelijke regels van bewijsrecht, terwijl in het bestuursrecht de vrije bewijsleer heerst. In deze paragraaf komen alleen aan de orde bewijsrechtelijke onderwerpen, die specifiek zien op het bewijs van causaal verband. 77 


\title{
De hoofdregel
}

Ook bij besluitenaansprakelijkheid draagt de verzoeker om schadevergoeding over het algemeen de bewijslast voor de causaliteit. ${ }^{\mathbf{8}}$

De Afdeling heeft bepaald dat bij een verzoek tot schadevergoeding op grond van artikel 8:73 Awb de rechter ambtshalve, dus zonder dat het bestuursorgaan het causaal verband betwist, mag overwegen dat geen sprake is van causaal verband tussen de schade en het onrechtmatige handelen. Door aldus te overwegen treedt de rechter volgens de Afdeling niet buiten grenzen van het geschil:

\begin{abstract}
"Het is aan de rechtbank om op het verzoek tot schadevergoeding op grond van artikel 8:73, eerste lid, van de Awb te onderzoeken of daarvoor gronden zijn. Dat het college zich niet heeft uitgelaten over het causaal verband tussen het niet tijdig beslissen en de beweerdelijk geleden schade, maakt - anders dan appellante kennelijk meent - niet dat de rechtbank het ervoor moest houden dat het college aansprakelijkheid voor schade voortvloeiende uit het niet tijdig beslissen had aanvaard."79
\end{abstract}

Deze uitspraak wijkt af van het civiele bewijsrecht. ${ }^{\mathbf{8 0}}$ De civiele rechter beschouwt namelijk op grond van artikel 149 lid 1 Rechtsvordering als vaststaand feiten of rechten die door de ene partij zijn gesteld en door de wederpartij niet of niet voldoende zijn betwist. Dit artikel leidt ertoe dat de civiele rechter niet ambtshalve tot het ontbreken van causaal verband mag oordelen.

\section{De omkeringsregel}

Ook in de bestuursrechtelijke context wordt de omkeringsregel toegepast. De Afdeling bestuursrechtspraak van de Raad van State sluit daarbij aan bij de jurisprudentie van de Hoge Raad over de omkeringsregel: voor toepassing van de 'omkeringsregel' is volgens de Afdeling namelijk slechts plaats als sprake is van schending van een norm die ertoe strekt een specifiek gevaar ter zake van het ontstaan van schade bij een ander te voorkomen en als dit gevaar door de normschending in het algemeen in aanmerkelijke mate wordt vergroot. ${ }^{\mathbf{8 1}}$ Ook de Centrale Raad van Beroep past de omkeringsregel toe bij schending van verkeer- en veiligheidsnormen. ${ }^{\mathbf{8 2}}$ Toch acht de Centrale Raad van Beroep zich met betrekking tot de omkeringsregel niet gebonden aan de jurisprudentie van de Hoge Raad. De Raad overwoog in een zaak, waarin appellante een beroep deed op de omkeringsregel en daarbij verwees naar de jurisprudentie van de Hoge Raad over dit onderwerp:

\footnotetext{
"Met betrekking tot de door appellante in dit verband genoemde arresten van de Hoge Raad merkt de raad op zich, gegeven de verschillen in stel- en bewijsplicht van partijen in het burgerlijk procesrecht en het bestuursprocesrecht, daaraan niet gebonden te achten." 83
}

Het College van Beroep voor het bedrijfsleven keert de bewijslast om in een zaak waarin het bestuursorgaan het motiveringsbeginsel geschonden had. De Minister van LNV had een gezondheidscertificaat afgegeven ten behoeve van de export van vogels naar Hong Kong en daarin onterecht geen verklaring opgenomen omtrent het West-Nijlvirus. Wegens het ontbreken van deze 
verklaring weigerde China de invoer van de vogels. Hierdoor leed de exporteur schade. Het $\mathrm{CBb}$ meent dat deze schade aan de Minister kan worden toegerekend, omdat hij door de betreffende verklaring niet op te nemen het risico heeft genomen dat de vogels zou worden geweigerd. Nu dit risico zich heeft verwezenlijkt dient volgens het $\mathrm{CBb}$ in beginsel te worden uitgegaan van een oorzakelijk verband tussen het onrechtmatig handelen en de ontstane schade. ${ }^{\mathbf{8 4}}$ Het lijkt erop of het $\mathrm{CBb}$ met deze bewoordingen wil aansluiten bij de omkeringsregel van de Hoge Raad, maar de vraag is of hij dat ook daadwerkelijk doet. De omkeringsregel speelt immers bij de vraag naar het bestaan van een condicio sine qua non verband en niet bij toepassing van de toerekeningsleer. Ook kun je je afvragen of het motiveringsbeginsel er wel toe strekt een specifiek gevaar ter zake van het ontstaan van schade bij een ander te voorkomen. ${ }^{85} \mathrm{Het}$ gaat hier in ieder geval niet om schending van een verkeers- of veiligheidsnorm. Met betrekking tot toepassing van de omkeringsregel bij besluitenaansprakelijkheid lijkt het mij goed om, zoals de Afdeling en de Centrale Raad van Beroep doen, aan te sluiten bij de 'civiele' omkeringsregel. Deze regel houdt naar huidig recht (in ieder geval) in dat bij schending van verkeers- en veiligheidsnormen door de overheid het condicio sine qua non verband tussen het onrechtmatige besluit en de schade in beginsel gegeven is. De ratio achter de omkeringregel is volgens de Hoge Raad dat het, gelet op de bescherming die een dergelijke norm beoogt te bieden, redelijk is om ervan uit te gaan dat bij verwezenlijking van het specifieke gevaar waartegen de norm beoogt te beschermen, dit een gevolg moet zijn geweest is van de normschending. ${ }^{\mathbf{8 6}} \mathrm{Dit}$ is mijns inziens niet anders bij schending van dergelijke normen in het geval van besluitenaansprakelijkheid. Ik zie ook geen andere reden om bij onrechtmatige besluiten van deze regel af te wijken.

In de literatuur worden de mogelijkheden van toepassing van de omkeringsregel in het bestuursrecht verder verkend. ${ }^{87}$ Aansprakelijkheid voor falend toezicht en gebrekkige handhaving hebben met betrekking tot dit onderwerp de bijzondere belangstelling. Albers denkt dat de omkeringsregel een belangrijke rol kan spelen in het kader van ontoereikend toezicht en gebrekkige handhaving. Gelet op het feit dat het bestuursorgaan vanwege het specialiteitsbeginsel beschikt over doelgebonden toezichts- en handhavingsbevoegdheden zal het volgens haar steeds gaan om het voorkomen van 'specifieke' gevaren en zal bovendien gebrekkig toezicht of niet-handhaven het verwezenlijken van het gevaar aanmerkelijk vergroten. Het lijkt haar dan ook logisch dat als dit specifieke gevaar zich verwezenlijkt de omkeringsregel van toepassing is. $\mathbf{8 8}$ Toepassing van de omkeringsregel bij falend toezicht is naar de mening van Kortmann niet aan de orde door het arrest Duwbak Linda. Hij stelt dat als een claim tegen de Staat als keuringsinstantie al afstuit op het relativiteitsvereiste van artikel 6:163 BW de omkeringsregel, die een veel specifiekere beschermingsomvang vereist, al helemaal niet meer in zicht komt. Handhaving is volgens Kortmann een lastige categorie, omdat de beginselplicht tot handhaving niet primair ziet op het voorkomen van schade, maar het bewust niet optreden tegen een brandgevaarlijk café lijkt hem toch een schending van een voldoende specifieke zorgvuldigheidsnorm om toepassing van de omkeringsregel te rechtvaardigen. Hij kan zich wel voorstellen dat het nalaten van bestuursdwang eerder toepassing van de omkeringsregel rechtvaardigt dan een dwangsom achterwege laten, omdat bestuursdwang het gevaar rechtstreeks wegneemt, terwijl een dwangsom minder direct de strekking heeft de 
geadresseerde daartoe te bewegen. ${ }^{\mathbf{8 9}}$

Ook Giesen bespreekt de toepasselijkheid van de omkeringsregel bij falend toezicht. Volgens hem is de ratio van de omkeringsregel (de handhaving van) de effectiviteit van de zorgvuldigheidsnorm: indien het causale verband steeds onbewijsbaar blijkt en aansprakelijkheid daarop afstuit, zal niemand die norm hoeven na te leven en kan deze uiteindelijk niet meer worden verwezenlijkt. De norm wordt dan 'inhoudsloos'. Bij toezichthouderaansprakelijkheid is er naar zijn mening geen sprake van dat het causale verband zo moeilijk is dat de aansprakelijkheid als regel daarop zal stuklopen. Zijn conclusie is dan ook dat de omkeringsregel, gezien de ratio daarvan, in beginsel niet van toepassing zal zijn bij aansprakelijkheid van de toezichthouder.90

De gedachte dat de omkeringsregel alleen van toepassing is bij bewijsnood is naar mijn mening echter geen gemeengoed.91 Ook uit de arresten van de Hoge Raad over de omkeringsregel blijkt een dergelijke ratio niet.92 $\mathrm{Er}$ is volgens mij geen reden om bij falend toezicht en gebrekkige handhaving af te wijken van de regel dat het condicio sine qua non verband vaststaat in het geval van schending van verkeers- of veiligheidsnormen. Dit betekent dat de bewijslast wel omgekeerd wordt als het gaat om falend toezicht bij een vuurwerkfabriek, waardoor een ontploffing plaatsvindt, en niet bij falend financieel toezicht. Dit geldt mijns inziens ook als de specifiek geschonden norm geen verkeers- of veiligheidsnorm is, maar het resultaat van die schending is dat het toezicht op de vuurwerkfabriek faalt, zoals bijvoorbeeld een termijnoverschrijding. De verplichting van adequaat toezicht door de overheid in dergelijke gevallen is immers in het leven geroepen ten behoeve van de veiligheid en beoogt (in ieder geval mede) de verwezenlijking van een specifiek gevaar te voorkomen. Met Kortmann ben ik van mening dat de ratio van de omkeringsregel toepassing ervan in die situaties rechtvaardigt. Het sluit in ieder geval aan bij de zienswijze van de Hoge Raad dat bescherming van de veiligheid een hoge prioriteit verdient.

Dat bij falend toezicht en gebrekkige handhaving vaak ook aansprakelijkheid bestaat van een primaire overtreder is niet van invloed op de toepassing van omkeringsregel.93 Het gaat er slechts om dat, behoudens tegenbewijs, voldaan is aan het vereiste van condicio sine qua non. Dat wil zeggen dat de schade niet was ontstaan zonder de gebrekkige handhaving of het falende toezicht. Dat meerdere oorzaken voor de schade bestaan, staat niet in de weg aan het aannemen van een condicio sine qua non verband.

\section{Omkering van de bewijslast}

Zoals gezegd in paragraaf 5.3.1. kan ingevolge artikel 150 Rechtsvordering omwille van de redelijkheid en billijkheid worden afgeweken van de hoofdregel dat de eiser het causaal verband dient te bewijzen.

Een omkering van de bewijslast toegesneden op de besluitenaansprakelijkheid past de Afdeling toe in de hiervoor besproken uitspraken van 15 december 2004:

\footnotetext{
"Indien een verzoek om vergoeding van schade als gevolg van een rechtens onjuist bevonden besluit wordt gedaan, is het aan het bestuursorgaan, dat dat besluit heeft genomen, om, als daartoe aanleiding bestaat, aannemelijk te maken dat ten tijde van het nemen van dat besluit ook een rechtmatig besluit zou hebben kunnen worden genomen in evenbedoelde zin. Dat later, zonder
} 
dat de daarvoor in aanmerking te nemen feiten en omstandigheden zijn gewijzigd, een besluit is genomen dat niet is vernietigd, maakt in beginsel aannemelijk dat zo'n besluit zou hebben kunnen worden genomen. ${ }^{94}$

Het is dus aan het bestuursorgaan om te bewijzen dat in plaats van het vernietigde besluit een rechtmatig besluit had kunnen worden genomen dat dezelfde schade tot gevolg zou hebben gehad.

Overigens volgt uit deze overweging niet dat het causale verband tussen de gestelde schade en het vernietigde besluit alleen dan onaannemelijk is, indien het bestuursorgaan aantoont dat ten tijde van het onrechtmatige besluit ook een rechtmatig besluit zou hebben kunnen worden genomen dat tot dezelfde schade zou hebben geleid. Toepasselijkheid bestaat alleen in zaken waarin een bestuursorgaan aanvoert dat in plaats van het onrechtmatige besluit ook een rechtmatig besluit met dezelfde inhoud had kunnen worden genomen.95 Indien later een rechtmatig besluit is genomen dat dezelfde schade zou hebben veroorzaakt gaat de Afdeling er, behoudens tegenbewijs, vanuit dat dit besluit ook ten tijde van het onrechtmatige besluit had kunnen worden genomen. ${ }^{\mathbf{9 6}}$ Dit maakt dat in de praktijk de uitkomst van de verlengde besluitvormingsprocedure van groot belang is voor de toewijsbaarheid van de schadevordering. Als een dergelijk besluit daadwerkelijk wordt genomen dan zal tegenbewijs niet makkelijk te leveren zijn. Ook de Hoge Raad keert in dergelijke situaties de bewijslast van het condicio sine qua non verband om.

Hij draagt het bestuursorgaan op te bewijzen dat de gestelde schade ook zou zijn geleden zonder het onrechtmatig handelen. ${ }^{97} \mathrm{Ik}$ vind het logisch dat de rechter in deze gevallen omwille van de redelijkheid en billijkheid de bewijslast op het bestuursorgaan legt. Het bestuursorgaan is de partij waar de benodigde informatie en expertise te vinden is. Voor een burger is bewijs van het tegendeel veel lastiger.

\subsubsection{Beoordeling en conclusie}

Bij besluitenaansprakelijkheid wordt over het algemeen aangesloten bij de hoofdregel van artikel 150 Rechtsvordering. Dit betekent dat de bewijslast van het causaal verband ligt op degene die schadevergoeding claimt. Wel wijkt de Afdeling bestuursrechtspraak van de Raad van State in een uitspraak af van de civiele bewijsregel van artikel 149 lid 1 Rechtsvordering dat de rechter niet ambtshalve tot het ontbreken van causaal verband mag oordelen. Op zich kan dit. In het bestuursrecht heerst immers de vrije bewijsleer. De bestuursrechter hoeft zich dus niet aan de strikte, wettelijke regels van het civiele bewijsrecht te houden. Vraag is wel waarom de Afdeling hier afwijkt, terwijl in andere opzichten juist wordt aangesloten bij de civiele rechtspraak over bewijs van causaal verband. Een dergelijke afwijking lijkt op zijn minst onnodig. Met betrekking tot de omkeringsregel sluiten de Afdeling en de Centrale Raad van Beroep in de praktijk aan bij de algemene toepassing ervan, hoewel de Centrale Raad zich uitdrukkelijk niet gebonden acht aan de jurisprudentie van de Hoge Raad over de omkeringsregel. Het College van Beroep voor het bedrijfsleven lijkt een eigen interpretatie van de omkeringsregel te hebben. Naar mijn mening bestaat er geen reden om bij falend toezicht en gebrekkige handhaving af te wijken van de regel dat het condicio sine qua non verband vaststaat in het geval van schending van verkeers- of veiligheidsnormen. 
Hieronder versta ik ook schending van normen, die als resultaat hebben dat het specifieke gevaar, waartegen de norm van adequate handhaving of adequaat toezicht wil beschermen, zich verwezenlijkt. Dit lijkt mij in overeenstemming met de ratio van de omkeringsregel.

Ten slotte vindt omkering van de bewijslast ook plaats met betrekking tot de vraag of in plaats van het onrechtmatige besluit een rechtmatig had kunnen worden genomen, dan wel zou zijn genomen dat dezelfde schade zou hebben veroorzaakt. Het komt mij logisch voor om in dergelijke gevallen omwille van de redelijkheid en billijkheid af te wijken van de hoofdregel, omdat het bestuursorgaan de sleutel(s) voor dit bewijs in handen heeft.

\subsubsection{Proportionele aansprakelijkheid}

Voor aansprakelijkheid uit onrechtmatige daad is in ieder geval een condicio sine qua non verband tussen de onrechtmatige daad en de schade vereist. Indien de benadeelde slaagt in het bewijs van het condicio sine qua non verband en de vordering ook voldoet aan de overige vereisten van artikel 6:162 BW, dan is de gedaagde aansprakelijk voor alle schade, die aan hem kan worden toegerekend op grond van artikel 6:98 BW. Kan hij het condicio sine qua non verband niet aantonen, dan zal hij niets van de geleden schade vergoed krijgen. In dit kader wordt wel gesproken over een 'alles of niets' systeem. In de meeste gevallen zal bewijs van condicio sine qua non verband niet al te veel problemen opleveren. Dit zal echter niet steeds het geval zijn. Om een dergelijk verband aan te tonen moet immers de hypothetische situatie, dat geen onrechtmatige daad heeft plaatsgevonden, worden vergeleken met de reële situatie, waarin dit wel is gebeurd. Soms is het echter praktisch onmogelijk om te weten of te bepalen wat er zonder de betreffende onrechtmatige daad gebeurd zou zijn. In het huidige systeem komt deze causaliteitsonzekerheid als hoofdregel ten laste van de benadeelde: hij zal zijn schade in het geheel niet vergoed krijgen, omdat hij het condicio sine qua non verband niet kan aantonen. Een veelgenoemd voorbeeld van dergelijke causaliteitsonzekerheid betreft werkgeversaansprakelijkheid: een werkgever heeft zijn zorgplicht geschonden door een werknemer tijdens zijn werk onrechtmatig aan asbest bloot te stellen. Deze werknemer krijgt longkanker en spreekt daarop de werkgever aan wegens de onrechtmatige blootstelling. De werkgever verweert zich door te stellen dat de longkanker niet is veroorzaakt door asbest, maar door de rookverslaving van de werknemer. Het is dan aan de werknemer om aan te tonen dat de longkanker is veroorzaakt door de bloostelling aan asbest: een onmogelijke opdracht. Zijn vordering tot schadevergoeding wordt dan geheel afgewezen. De werknemer zou in een dergelijke situatie dus geen enkel gedeelte van zijn schade vergoed krijgen, terwijl de werkgever toch onrechtmatig jegens hem heeft gehandeld. Zou de bewijslast in dergelijke situaties worden omgedraaid dan komt de causaliteitsonzekerheid geheel bij de normschender te liggen. Als hij het bestaan van een condicio sine qua non verband niet voldoende kan ontkrachten, dan dient hij de gehele schade van de benadeelde te vergoeden, terwijl hij deze (misschien) niet (geheel) heeft veroorzaakt. In de literatuur is gewezen op de rigoureuze uitwerking van dit 'alles of niets' systeem en de onwenselijkheid hiervan. Als alternatief wordt een proportionele aansprakelijkheid bepleit. ${ }^{\mathbf{9 8}} \mathrm{Dit}$ houdt in dat een bepaald percentage van de schade door de normschender wordt vergoed naar rato van waarschijnlijkheid dat hij de schade heeft veroorzaakt. Als 
een vorm van proportionele aansprakelijkheid wordt ook gezien de vergoedbaarheid van het 'verlies van een kans' ${ }^{99} \mathrm{Er}$ is echter ook de nodige tegenstand. ${ }^{\mathbf{1 0 0}}$ In recente jurisprudentie lijkt de rechter de mogelijkheid van proportionele aansprakelijkheid te aanvaarden. ${ }^{\mathbf{1 0 1}} \mathrm{Hij}$ beperkt zich hierbij uitdrukkelijk niet tot werkgeversaansprakelijkheid. ${ }^{\mathbf{1 0 2}}$ De Hoge Raad is van mening dat bij de toepassing van proportionele aansprakelijkheid de rechter in zijn motivering dient te verantwoorden dat de strekking van de geschonden norm en de aard van de normschending (waaronder begrepen de aard van de schade) deze toepassing in het concrete geval rechtvaardigen. Ook dient deze regel volgens de Hoge Raad met terughoudendheid te worden toegepast. Voor toepassing van proportionele aansprakelijkheid kan met name aanleiding zijn indien de aansprakelijkheid van de aangesproken partij op zichzelf vaststaat, een niet zeer kleine kans bestaat dat het condicio sine qua non verband tussen de geschonden norm en de schade aanwezig is, en de strekking van de geschonden norm en de aard van de normschending de toepassing ervan rechtvaardigen. ${ }^{\mathbf{1 0 3}}$ De Centrale Raad van Beroep neemt proportionele aansprakelijkheid van de overheid als werkgever aan bij causaliteitsonzekerheid met betrekking tot de vraag of de longkanker van de (oud)werknemer is veroorzaakt door onrechtmatige blootstelling aan asbest tijdens zijn werk of zijn rookgedrag. ${ }^{\mathbf{1 0 4}}$ Dit sluit aan bij de jurisprudentie over werkgeversaansprakelijkheid van private werkgevers over dezelfde vraag. ${ }^{\mathbf{1 0 5}}$

\section{De hoofdregel}

Ook bij besluitenaansprakelijkheid draagt de verzoeker om schadevergoeding over het algemeen de bewijslast voor de causaliteit. ${ }^{\mathbf{1 0 6}}$

De Afdeling heeft bepaald dat bij een verzoek tot schadevergoeding op grond van artikel 8:73 Awb de rechter ambtshalve, dus zonder dat het bestuursorgaan het causaal verband betwist, mag overwegen dat geen sprake is van causaal verband tussen de schade en het onrechtmatige handelen. Door aldus te overwegen treedt de rechter volgens de Afdeling niet buiten grenzen van het geschil:

\footnotetext{
"Het is aan de rechtbank om op het verzoek tot schadevergoeding op grond van artikel 8:73, eerste lid, van de Awb te onderzoeken of daarvoor gronden zijn. Dat het college zich niet heeft uitgelaten over het causaal verband tussen het niet tijdig beslissen en de beweerdelijk geleden schade, maakt - anders dan appellante kennelijk meent - niet dat de rechtbank het ervoor moest houden dat het college aansprakelijkheid voor schade voortvloeiende uit het niet tijdig beslissen had aanvaard."107
}

Deze uitspraak wijkt af van het civiele bewijsrecht. ${ }^{\mathbf{1 0 8}}$ De civiele rechter beschouwt namelijk op grond van artikel 149 lid 1 Rechtsvordering als vaststaand feiten of rechten die door de ene partij zijn gesteld en door de wederpartij niet of niet voldoende zijn betwist. Dit artikel leidt ertoe dat de civiele rechter niet ambtshalve tot het ontbreken van causaal verband mag oordelen.

\section{De omkeringsregel}

Ook in de bestuursrechtelijke context wordt de omkeringsregel toegepast.

De Afdeling bestuursrechtspraak van de Raad van State sluit daarbij aan bij de 
jurisprudentie van de Hoge Raad over de omkeringsregel: voor toepassing van de 'omkeringsregel' is volgens de Afdeling namelijk slechts plaats als sprake is van schending van een norm die ertoe strekt een specifiek gevaar ter zake van het ontstaan van schade bij een ander te voorkomen en als dit gevaar door de normschending in het algemeen in aanmerkelijke mate wordt vergroot. ${ }^{109}$ Ook de Centrale Raad van Beroep past de omkeringsregel toe bij schending van verkeer- en veiligheidsnormen. ${ }^{\mathbf{1 1 0}}$ Toch acht de Centrale Raad van Beroep zich met betrekking tot de omkeringsregel niet gebonden aan de jurisprudentie van de Hoge Raad. De Raad overwoog in een zaak, waarin appellante een beroep deed op de omkeringsregel en daarbij verwees naar de jurisprudentie van de Hoge Raad over dit onderwerp:
"Met betrekking tot de door appellante in dit verband genoemde arresten van de Hoge Raad merkt de raad op zich, gegeven de verschillen in stel- en bewijsplicht van partijen in het burgerlijk procesrecht en het bestuursprocesrecht, daaraan niet gebonden te achten."111

Het College van Beroep voor het bedrijfsleven keert de bewijslast om in een zaak waarin het bestuursorgaan het motiveringsbeginsel geschonden had. De Minister van LNV had een gezondheidscertificaat afgegeven ten behoeve van de export van vogels naar Hong Kong en daarin onterecht geen verklaring opgenomen omtrent het West-Nijlvirus. Wegens het ontbreken van deze verklaring weigerde China de invoer van de vogels. Hierdoor leed de exporteur schade. Het $\mathrm{CBb}$ meent dat deze schade aan de Minister kan worden toegerekend, omdat hij door de betreffende verklaring niet op te nemen het risico heeft genomen dat de vogels zou worden geweigerd. Nu dit risico zich heeft verwezenlijkt dient volgens het $\mathrm{CBb}$ in beginsel te worden uitgegaan van een oorzakelijk verband tussen het onrechtmatig handelen en de ontstane schade. ${ }^{\mathbf{1 1 2}}$ Het lijkt erop of het $\mathrm{CBb}$ met deze bewoordingen wil aansluiten bij de omkeringsregel van de Hoge Raad, maar de vraag is of hij dat ook daadwerkelijk doet. De omkeringsregel speelt immers bij de vraag naar het bestaan van een condicio sine qua non verband en niet bij toepassing van de toerekeningsleer. Ook kun je je afvragen of het motiveringsbeginsel er wel toe strekt een specifiek gevaar ter zake van het ontstaan van schade bij een ander te voorkomen. ${ }^{\mathbf{1 1 3}} \mathrm{Het}$ gaat hier in ieder geval niet om schending van een verkeers- of veiligheidsnorm. Met betrekking tot toepassing van de omkeringsregel bij besluitenaansprakelijkheid lijkt het mij goed om, zoals de Afdeling en de Centrale Raad van Beroep doen, aan te sluiten bij de 'civiele' omkeringsregel. Deze regel houdt naar huidig recht (in ieder geval) in dat bij schending van verkeers- en veiligheidsnormen door de overheid het condicio sine qua non verband tussen het onrechtmatige besluit en de schade in beginsel gegeven is. De ratio achter de omkeringregel is volgens de Hoge Raad dat het, gelet op de bescherming die een dergelijke norm beoogt te bieden, redelijk is om ervan uit te gaan dat bij verwezenlijking van het specifieke gevaar waartegen de norm beoogt te beschermen, dit een gevolg moet zijn geweest is van de normschending. ${ }^{\mathbf{1 1 4}} \mathrm{Dit}$ is mijns inziens niet anders bij schending van dergelijke normen in het geval van besluitenaansprakelijkheid. Ik zie ook geen andere reden om bij onrechtmatige besluiten van deze regel af te wijken.

In de literatuur worden de mogelijkheden van toepassing van de omkeringsregel in het bestuursrecht verder verkend. ${ }^{\mathbf{1 1 5}}$ Aansprakelijkheid voor falend toezicht 
en gebrekkige handhaving hebben met betrekking tot dit onderwerp de bijzondere belangstelling. Albers denkt dat de omkeringsregel een belangrijke rol kan spelen in het kader van ontoereikend toezicht en gebrekkige handhaving. Gelet op het feit dat het bestuursorgaan vanwege het specialiteitsbeginsel beschikt over doelgebonden toezichts- en handhavingsbevoegdheden zal het volgens haar steeds gaan om het voorkomen van 'specifieke' gevaren en zal bovendien gebrekkig toezicht of niet-handhaven het verwezenlijken van het gevaar aanmerkelijk vergroten. Het lijkt haar dan ook logisch dat als dit specifieke gevaar zich verwezenlijkt de omkeringsregel van toepassing is. ${ }^{\mathbf{1 1 6}}$ Toepassing van de omkeringsregel bij falend toezicht is naar de mening van Kortmann niet aan de orde door het arrest Duwbak Linda. Hij stelt dat als een claim tegen de Staat als keuringsinstantie al afstuit op het relativiteitsvereiste van artikel 6:163 BW de omkeringsregel, die een veel specifiekere beschermingsomvang vereist, al helemaal niet meer in zicht komt. Handhaving is volgens Kortmann een lastige categorie, omdat de beginselplicht tot handhaving niet primair ziet op het voorkomen van schade, maar het bewust niet optreden tegen een brandgevaarlijk café lijkt hem toch een schending van een voldoende specifieke zorgvuldigheidsnorm om toepassing van de omkeringsregel te rechtvaardigen. Hij kan zich wel voorstellen dat het nalaten van bestuursdwang eerder toepassing van de omkeringsregel rechtvaardigt dan een dwangsom achterwege laten, omdat bestuursdwang het gevaar rechtstreeks wegneemt, terwijl een dwangsom minder direct de strekking heeft de geadresseerde daartoe te bewegen. ${ }^{\mathbf{1 1 7}}$

Ook Giesen bespreekt de toepasselijkheid van de omkeringsregel bij falend toezicht. Volgens hem is de ratio van de omkeringsregel (de handhaving van) de effectiviteit van de zorgvuldigheidsnorm: indien het causale verband steeds onbewijsbaar blijkt en aansprakelijkheid daarop afstuit, zal niemand die norm hoeven na te leven en kan deze uiteindelijk niet meer worden verwezenlijkt. De norm wordt dan 'inhoudsloos'. Bij toezichthouderaansprakelijkheid is er naar zijn mening geen sprake van dat het causale verband zo moeilijk is dat de aansprakelijkheid als regel daarop zal stuklopen. Zijn conclusie is dan ook dat de omkeringsregel, gezien de ratio daarvan, in beginsel niet van toepassing zal zijn bij aansprakelijkheid van de toezichthouder. ${ }^{\mathbf{1 1 8}}$

De gedachte dat de omkeringsregel alleen van toepassing is bij bewijsnood is naar mijn mening echter geen gemeengoed. ${ }^{\mathbf{1 1 9}}$ Ook uit de arresten van de Hoge Raad over de omkeringsregel blijkt een dergelijke ratio niet. ${ }^{\mathbf{1 2 0}} \mathrm{Er}$ is volgens mij geen reden om bij falend toezicht en gebrekkige handhaving af te wijken van de regel dat het condicio sine qua non verband vaststaat in het geval van schending van verkeers- of veiligheidsnormen. Dit betekent dat de bewijslast wel omgekeerd wordt als het gaat om falend toezicht bij een vuurwerkfabriek, waardoor een ontploffing plaatsvindt, en niet bij falend financieel toezicht. Dit geldt mijns inziens ook als de specifiek geschonden norm geen verkeers- of veiligheidsnorm is, maar het resultaat van die schending is dat het toezicht op de vuurwerkfabriek faalt, zoals bijvoorbeeld een termijnoverschrijding. De verplichting van adequaat toezicht door de overheid in dergelijke gevallen is immers in het leven geroepen ten behoeve van de veiligheid en beoogt (in ieder geval mede) de verwezenlijking van een specifiek gevaar te voorkomen. Met Kortmann ben ik van mening dat de ratio van de omkeringsregel toepassing ervan in die situaties rechtvaardigt. Het sluit in ieder geval aan bij de zienswijze van de Hoge Raad dat bescherming van de veiligheid een hoge prioriteit 
verdient.

Dat bij falend toezicht en gebrekkige handhaving vaak ook aansprakelijkheid bestaat van een primaire overtreder is niet van invloed op de toepassing van omkeringsregel. ${ }^{\mathbf{1 2 1}}$ Het gaat er slechts om dat, behoudens tegenbewijs, voldaan is aan het vereiste van condicio sine qua non. Dat wil zeggen dat de schade niet was ontstaan zonder de gebrekkige handhaving of het falende toezicht. Dat meerdere oorzaken voor de schade bestaan, staat niet in de weg aan het aannemen van een condicio sine qua non verband.

Omkering van de bewijslast

Zoals gezegd in paragraaf 5.3.1. kan ingevolge artikel 150 Rechtsvordering omwille van de redelijkheid en billijkheid worden afgeweken van de hoofdregel dat de eiser het causaal verband dient te bewijzen.

Een omkering van de bewijslast toegesneden op de besluitenaansprakelijkheid past de Afdeling toe in de hiervoor besproken uitspraken van 15 december 2004:
"Indien een verzoek om vergoeding van schade als gevolg van een rechtens onjuist bevonden besluit wordt gedaan, is het aan het bestuursorgaan, dat dat besluit heeft genomen, om, als daartoe aanleiding bestaat, aannemelijk te maken dat ten tijde van het nemen van dat besluit ook een rechtmatig besluit zou hebben kunnen worden genomen in evenbedoelde zin. Dat later, zonder dat de daarvoor in aanmerking te nemen feiten en omstandigheden zijn gewijzigd, een besluit is genomen dat niet is vernietigd, maakt in beginsel aannemelijk dat zo'n besluit zou hebben kunnen worden genomen. ${ }^{\mathbf{1 2 2}}$

Het is dus aan het bestuursorgaan om te bewijzen dat in plaats van het vernietigde besluit een rechtmatig besluit had kunnen worden genomen dat dezelfde schade tot gevolg zou hebben gehad.

Overigens volgt uit deze overweging niet dat het causale verband tussen de gestelde schade en het vernietigde besluit alleen dan onaannemelijk is, indien het bestuursorgaan aantoont dat ten tijde van het onrechtmatige besluit ook een rechtmatig besluit zou hebben kunnen worden genomen dat tot dezelfde schade zou hebben geleid. Toepasselijkheid bestaat alleen in zaken waarin een bestuursorgaan aanvoert dat in plaats van het onrechtmatige besluit ook een rechtmatig besluit met dezelfde inhoud had kunnen worden genomen. ${ }^{\mathbf{1 2 3}}$ Indien later een rechtmatig besluit is genomen dat dezelfde schade zou hebben veroorzaakt gaat de Afdeling er, behoudens tegenbewijs, vanuit dat dit besluit ook ten tijde van het onrechtmatige besluit had kunnen worden genomen. ${ }^{\mathbf{1 2 4}}$ Dit maakt dat in de praktijk de uitkomst van de verlengde besluitvormingsprocedure van groot belang is voor de toewijsbaarheid van de schadevordering. Als een dergelijk besluit daadwerkelijk wordt genomen dan zal tegenbewijs niet makkelijk te leveren zijn. Ook de Hoge Raad keert in dergelijke situaties de bewijslast van het condicio sine qua non verband om.

Hij draagt het bestuursorgaan op te bewijzen dat de gestelde schade ook zou zijn geleden zonder het onrechtmatig handelen. ${ }^{\mathbf{1 2 5}} \mathrm{Ik}$ vind het logisch dat de rechter in deze gevallen omwille van de redelijkheid en billijkheid de bewijslast op het bestuursorgaan legt. Het bestuursorgaan is de partij waar de benodigde informatie en expertise te vinden is. Voor een burger is bewijs van het tegendeel veel lastiger. 


\section{De Toerekeningsleer}

\subsection{De leer van de redelijke toerekening van artikel 6:98 BW}

Staat het condicio sine qua non verband vast, dan bakent artikel 6:98 BW de omvang van de aansprakelijkheid af. Voor vergoeding komt slechts in aanmerking schade die in zodanig verband staat met de gebeurtenis waarop de aansprakelijkheid van de schuldenaar berust, dat zij hem, mede gezien de aard van de aansprakelijkheid en van de schade, als een gevolg van deze gebeurtenis kan worden toegerekend. Dit wordt de toerekeningsleer genoemd en betreft een rechtsvraag. De toerekeningsvraag gaat niet over verdeling van de schade. Als bijvoorbeeld op grond van artikel 6:98 BW de geleden zaakschade aan de betreffende onrechtmatige daad kan worden toegerekend, dat dient de normschender de gehele schade aan deze zaak te vergoeden.

In de Parlementaire Geschiedenis van het Nieuw Burgerlijk Wetboek is aandacht besteed aan de vraag welk criterium het meest geschikt was om het causaal verband nader te bepalen. In het oorspronkelijke ontwerp was daartoe het voorzienbaarheidsvereiste opgenomen, dat ten tijde van het ontwerp algemeen was aanvaard. Volgens dit vereiste speelde de voorzienbaarheid van de geleden schade een doorslaggevende rol bij beantwoording van de vraag of sprake was van voldoende causaal verband. Op deze leer is in de jaren zestig kritiek gekomen. ${ }^{\mathbf{1 2 6}}$ Het vereiste zou te vaag zijn en op die manier wenselijkheidsbeslissingen in de hand werken, waarbij de werkelijke argumenten van de rechter om al dan niet aansprakelijkheid aan te nemen niet uit de uitspraak zouden blijken. ${ }^{\mathbf{1 2 7}}$

Rond 1970 heeft de Hoge Raad de voorzienbaarheidsleer verlaten en vervangen door de toerekeningsleer. De wetgever heeft deze leer vervolgens gecodificeerd in artikel 6:98 BW. De keuze voor de toerekeningsleer wordt door de betrokken minister als volgt beargumenteerd:

\footnotetext{
"Zoals de Commissie (...) heeft opgemerkt, heeft de toerekeningsmaatstaf het voordeel dat de rechter verplicht is - en ook in de gelegenheid - zijn beslissing te motiveren met de werkelijke overwegingen die daaraan ten grondslag liggen."
}

De wetgever hoopte dus dat de toerekeningsleer zou leiden tot rechterlijke uitspraken, waaruit uitdrukkelijk zou blijken op grond van welke argumenten de rechter daadwerkelijk tot zijn conclusie omtrent het causaal verband was gekomen. Dit zou moeten gebeuren aan de hand van objectieve criteria:

\footnotetext{
"De toerekening dient uiteraard te geschieden naar objectieve inzichten. Een uitdrukkelijk verwijzing naar de redelijkheid is (...) achterwege gelaten teneinde niet te suggereren als zou het hier gaan om een discretionaire bevoegdheid van de rechter, waarbij hij aan geen andere maatstaf dan de redelijkheid gebonden zou zijn. De vraag of de schade aan de aansprakelijke als een gevolg van de (...) bedoelde gebeurtenissen kan worden toegerekend, moet in beginsel worden gezien als een rechtsvraag, die beantwoord moet worden aan de hand van objectieve factoren als de aard van de aansprakelijkheid en van de schade." 128
} 
De wetgever heeft in artikel 6:98 BW de aard van de aansprakelijkheid en de aard van de schade genoemd als criteria, die een rol spelen bij beantwoording van de toerekeningsvraag. Deze opsomming is niet limitatief. De toerekeningsleer gaat uit van een multi-factor benadering. Aan de hand van objectieve factoren, in onderlinge verhouding bezien, dient de rechter te beoordelen of voldaan is aan het vereiste van toerekening. ${ }^{\mathbf{1 2 9}}$ Op deze manier ontstaan deelregels van causaal verband ter invulling van het ruime criterium van artikel 6:98 BW. Brunner heeft in 1981 uit de jurisprudentie van de Hoge Raad deelregels van causaliteit afgeleid. ${ }^{\mathbf{1 3 0}}$ Deze regels worden in het huidige recht nog steeds toegepast en luiden:131

1. Naarmate het gevolg naar ervaringsregels waarschijnlijker is, is toerekening eerder gerechtvaardigd. Omgekeerd is toerekening minder aanvaardbaar naar mate het gevolg uitzonderlijker, abnormaler en minder waarschijnlijk is.

2. Naarmate het schadelijke gevolg minder ver verwijderd is van de gebeurtenis waarop de aansprakelijkheid berust, is toerekening eerder gerechtvaardigd.

3. De aard van de aansprakelijkheid kan meebrengen dat schade ruim dan wel beperkt moet worden toegerekend. Deze algemene regel kan worden gesplitst in een aantal deelregels:

a. Voor iedere beschermingsnorm kan en moet worden vastgesteld of het doel waarmee zij in het leven is geroepen toerekening van de in concreto gevorderde schade rechtvaardigt.

b. Verkeers- en veiligheidsnormen die met het oog op de voorkoming van ongevallen zijn opgesteld, rechtvaardigen een ruime toerekening van overlijdens- en letselschade.

c. Aansprakelijkheid zonder schuld geeft in beginsel aanleiding tot een beperkte toerekening van schade; naar mate de schuld aan het schadeveroorzakend gebeuren zwaarder is, is ruimere toerekening van schade meer gerechtvaardigd.

d. Schade door dood of letsel wordt eerder toegerekend dan zaakschade, zaakschade eerder dan schade die bestaat in extra kosten en uitgaven en schade door vermogensverlies eerder dan de derving van winst.

De deelregels geven aan welke factoren een belangrijke rol spelen bij beantwoording van de toerekeningsvraag. Van de concrete omstandigheden van het geval hangt af welke factoren de rechter meeweegt en hoe deze factoren zich tot elkaar verhouden. Ook kunnen nog andere factoren dan hier genoemd een rol spelen. Hieronder volgt een korte toelichting op de besproken causaliteitsregels.

\section{Ad 1) Voorzienbaarheid}


De regel dat naarmate de schade minder waarschijnlijk is, toerekening minder snel wordt aangenomen, geldt volgens de jurisprudentie niet bij schending van verkeers- en veiligheidsnormen. In dat geval wordt ook schade, die buiten de normale lijn der verwachting ligt, toegerekend..$^{\mathbf{1 3 2}}$ Dat het herstel langer duurt dan gebruikelijk als gevolg van moeilijkheden in het privéleven van het slachtoffer of diens persoonlijkheidsstructuur doet hieraan niet af. ${ }^{\mathbf{1 3 3}}$ Voor een uitzondering op deze regel is slechts plaats onder bijzondere omstandigheden, bijvoorbeeld als het slachtoffer zich van zijn kant onvoldoende inspant om een bijdrage te leveren aan het herstelproces. ${ }^{\mathbf{1 3 4}}$

\section{Ad 2) Verwijderdheid schade van onrechtmatige daad.}

Aangenomen wordt dat ook de mate waarin de schade verwijderd is van de gebeurtenis waarop aansprakelijkheid berust een rol speelt bij de toerekening. De verwijderdheid betreft de lengte van de causale keten. ${ }^{\mathbf{1 3 5}}$ Deze regel kan volgens Brunner de noodzakelijke beperkingen stellen aan de toerekening voor tweede- en meerderegraadsschade. ${ }^{\mathbf{1 3 6}}$ Het is zeker niet zo dat tweedegraadsschade in de jurisprudentie als regel van vergoeding wordt uitgesloten. De Hoge Raad heeft bijvoorbeeld aangenomen dat onder bepaalde omstandigheden voor vergoeding in aanmerking komt schade, die wordt geleden door afnemers van gas of elektriciteit bij beschadiging van gas- of elektriciteitkabels. De schade bestaat er dan in dat door het gebrek aan gas of elektriciteit het productieproces in de betreffende fabrieken moet worden stilgelegd. Dergelijke stagnatieschade wordt gezien als tweedegraadsschade. ${ }^{137}$ Het enkele feit dat toerekening van tweede- en verderegraadsschade tot een lawine van claims kan leiden hoeft aan de toerekening op zichzelf niet in de weg te staan..$^{\mathbf{3 8}}$

\section{Ad 3) Aard van de aansprakelijkheid}

Doel van de geschonden norm

Bij de vraag of toerekening in het concrete geval gerechtvaardigd is, dient steeds te worden gekeken naar beschermingsdoel- en strekking, alsmede naar beschermingsomvang van de geschonden norm. ${ }^{\mathbf{1 3 9}}$

Ook uit de rechtspraak blijkt dat bij de toerekeningsvraag de strekking van de geschonden norm een factor van belang kan zijn. ${ }^{\mathbf{1 4 0}}$

Verkeers- en veiligheidsnormen

Bij schending van een verkeers- of veiligheidsnorm wordt zeer ruim toegerekend. Bij overtreding van deze normen moet rekening worden gehouden met de mogelijkheid van ernstige gevolgen, hoe deze zich ook in het concrete geval mogen voordoen. ${ }^{\mathbf{1 4 1}}$ De ruime toerekening wordt gerechtvaardigd geacht doordat de strekking van deze normen is het voorkomen van ongevallen. ${ }^{\mathbf{1 4 2}}$

Risico-aansprakelijkheid

Tegenwoordig wordt wel aangenomen dat bij risicoaansprakelijkheid niet steeds een beperkte toerekening gerechtvaardigd is. Beslissend is de strekking van de geschonden norm. ${ }^{\mathbf{1 4 3}}$ 


\section{Ad 4) Aard van de schade}

Letselschade wordt, vanwege het ernstige karakter daarvan, ruim toegerekend. Dit geldt ook als de letselschade in een verder verwijderd verband staat met de onrechtmatige daad of weinig waarschijnlijk is. ${ }^{\mathbf{1 4 4}}$ Ook als het niet gaat om schending van verkeers- en veiligheidsnormen wordt letselschade ruim toegerekend. ${ }^{145}$

\subsection{Toepassing van de leer van de redelijke toerekening bij besluitenaansprakelijkheid}

\subsubsection{Inleiding}

Deze paragraaf gaat over de toepassing van de toerekeningsleer in het geval van besluitenaansprakelijkheid. Onderzocht wordt welke toerekeningsfactoren een rol spelen bij de vraag of de schade aan het onrechtmatige besluit kan worden toegerekend en in hoeverre dit verschilt van de in paragraaf 6.1. besproken toerekeningsfactoren van Brunner. Wanneer aan de orde zal worden bekeken waarom dit verschil bestaat. Uit het jurisprudentieonderzoek blijkt wederom dat de afwijkende toepassing zich voordoet bij de bestuursrechter. Het valt op dat de bestuursrechter regelmatig schadeverzoeken afwijst wegens het ontbreken van toerekening, omdat de schade volgens hem wordt veroorzaakt door andere omstandigheden dan het onrechtmatige besluit. Deze toerekeningsfactor wordt behandeld in paragraaf 6.2.2. De Centrale Raad van Beroep hanteert tevens de aard en strekking van het vernietigde besluit als toerekeningsfactor. Hierover gaat paragraaf 6.2.3. In paragraaf 6.2.4. komt ten slotte aan bod het feit dat de (overige) toerekeningsregels van Brunner nauwelijks een rol spelen in de rechtspraak over besluitenaansprakelijkheid.

\subsubsection{De schade wordt veroorzaakt door 'andere omstandigheden' dan het vernietigde besluit}

Jurisprudentie

De bestuursrechter wijst in zaken van besluitenaansprakelijkheid de schadeclaim regelmatig af, omdat de schade volgens hem is veroorzaakt door andere omstandigheden dan het onrechtmatige besluit. Deze rechtspraak wordt vaak negatief beoordeeld. In sommige uitspraken van de Centrale Raad wordt de genoemde conclusie overigens gekoppeld aan de aard en strekking van het vernietigde besluit. Dit onderwerp komt in paragraaf 6.2.3. aan bod.

Ik vind de betreffende jurisprudentie opvallend. In zaken tussen civiele partijen speelt namelijk het feit dat ook andere schadeoorzaken bestaan geen (zichtbare) rol bij de toerekeningsvraag van artikel 6:98 BW. In het kader van dit artikel is het van belang het geconstateerde verschil te duiden en mogelijke redenen hiervoor te onderzoeken. Daartoe heb ik ten eerste de bedoelde uitspraken van de bestuursrechter nader bestudeerd.

De betreffende andere omstandigheden houden in dat de rechter meent dat de schade wordt veroorzaakt door a) omstandigheden die voortvloeien uit de inhoud van het onrechtmatige besluit of daarmee nauw samenhangen of b) omstandigheden die bij de benadeelden zelf liggen. In sommige uitspraken spelen nog c) overige omstandigheden een rol. Ook worden schadeclaims 
afgewezen wegens een combinatie van deze omstandigheden.

Ad a

De Koninklijke Luchtmacht heeft met bedrijf X een overeenkomst gesloten, die inhoudt dat X voor in Nederland gestationeerde F16 vliegtuigen het onderhoud zal verzorgen. ${ }^{\mathbf{1 4 6}}$ Daartoe worden met name in de Verenigde Staten technici geworven, die vervolgens worden uitgezonden naar Nederland. De monteurs hebben een arbeidsovereenkomst met X en zijn op detacheringsbasis werkzaam bij de Koninklijke Luchtmacht. Appellante in de schadevergoedingsprocedure treedt in Nederland op als agent van X en verzorgt namens X onder meer de praktische uitvoering van het contract met de Luchtmacht, waaronder begrepen de logistieke ondersteuning en de behartiging van andere praktische zaken van de Amerikaanse werknemers van X. Bij besluit van 16 september 1996 heeft De Raad van Bestuur van het Uwv zich op het standpunt gesteld dat appellante premies verschuldigd is ingevolge de sociale werknemersverzekeringswetten over de aan de hier te lande werkzame Amerikaanse F16 monteurs verrichte betalingen. Met deze premies was bij de vaststelling van de vergoeding die appellante van $\mathrm{X}$ ontving geen rekening gehouden. In reactie op dit besluit heeft de Luchtmacht besloten tot een minimale inzet van F16 monteurs, naar ik begrijp omdat zij bang was deze premies zelf te moeten voldoen. Appellante vecht het besluit aan. Het besluit wordt in eerste instantie gehandhaafd, maar in beroep door de rechtbank vernietigd. X vordert daarop o.a. schadevergoeding wegens gederfde winst van het Uwv, omdat de Luchtmacht op grond van het onrechtmatige besluit heeft besloten tot minimale inzet van F16 monteurs. De Centrale Raad sluit met betrekking tot het causaal verband aan bij de bewoordingen van artikel 6:98 BW en stelt dat, wil schade op grond van artikel 8:73 Awb voor vergoeding in aanmerking komen, deze in zodanig verband moet staan met het vernietigde besluit dat zij het bestuursorgaan, mede gezien de aard van de aansprakelijkheid en van de schade, als een gevolg van dat besluit kan worden toegerekend. Hierbij acht de Raad ook de aard en de strekking van het vernietigde besluit van belang. Vervolgens wijst de Raad het verzoek tot schadevergoeding af wegens ontbreken van causaal verband. De reden:

\begin{abstract}
"Vastgesteld moet worden dat de Klu met $\mathrm{X}$ had gecontracteerd over de inzet van Amerikaanse F16-monteurs hier te lande en daarnaast appellante met $X$ had gecontracteerd over de logistieke ondersteuning van deze monteurs. De schade die appellante stelt te hebben geleden, is een uitvloeisel van de wijze waarop de Klu en $\mathrm{X}$ hun (contractuele) relatie naar aanleiding van de besluitvorming van gedaagde nader hebben ingevuld. Dat deze nadere invulling een voorzienbaar en onontkoombaar gevolg was van deze besluitvorming, acht de Raad met de rechtbank niet, althans onvoldoende aannemelijk gemaakt. Dit betekent dat er geen grond aanwezig is om de gestelde schade toe te rekenen aan de onrechtmatig genomen besluiten."
\end{abstract}

Een imkervereniging heeft in strijd met de bepalingen van het bestemmingsplan bijen op een perceel gehouden. ${ }^{\mathbf{1 4 7}}$ Omwonenden hebben het college van Burgemeester en Wethouders van Haarlemmermeer om handhaving verzocht. Het college heeft in strijd met de beginselplicht tot handhaving dit verzoek geweigerd. Pas nadat de Rechtbank de weigering tot handhaving heeft 
vernietigd, is het college tot handhaving overgegaan. Omwonenden verzoeken de gemeente vervolgens om vergoeding van schade, die zij stellen te hebben geleden als gevolg van het door de vereniging in strijd met de bepalingen van het bestemmingsplan houden van bijen. De schade bestaat o.a. uit gederfd woongenot. De vordering tot vergoeding van deze schade wordt afgewezen wegens het ontbreken van causaal verband. De Afdeling:

"De gestelde schade is veroorzaakt door het door de vereniging houden van bijen ter plaatse."

Van Ravels vraagt zich in zijn noot bij deze uitspraak af hoe we deze overweging moeten duiden. Betekent dit dat de gestelde schade niet is veroorzaakt door het bestuursorgaan dat ten onrechte weigerde (tijdig) te handhaven? Of moeten we deze overweging zo begrijpen dat de omstandigheid dat een derde de primaire veroorzaker is van de schade een factor is die medebepalend is voor het antwoord op de vraag of de schade in redelijkheid kan worden toegerekend aan de weigering van het bestuursorgaan? Van Ravels denkt het laatste.

In de volgende zaak is ten onrechte geen vergunning toegekend voor het invoeren van 500 Vierteenlandschilpadden. ${ }^{\mathbf{1 4 8}}$ Het oorspronkelijke besluit tot weigering van de vergunning was gebaseerd op een onjuiste verordening. Hierop dient de importeur een verzoek tot schadevergoeding in. De schade bestaat volgens hem uit gederfde winst: hij is een geldelijke verplichting aangegaan, maar heeft de betreffende dieren niet kunnen afnemen, omdat de leverancier deze niet langer kosteloos in bewaring wilde houden tijdens de procedure tegen de weigering van de vergunning. De importeur stelt uiteindelijk van de koop te hebben afgezien om schade te beperken, ook omdat dergelijke procedures veelal lang duren. De Rechtbank is van mening dat causaal verband ontbreekt, nu de schade 'niet alleen' door het onrechtmatige besluit is veroorzaakt, maar vooral door de door de importeur gegeven toestemming aan de buitenlandse leverancier om de schildpadden te laten verkopen. De Afdeling is het hiermee eens:

"De Afdeling deelt de zienswijze van de rechtbank dat de gestelde schade niet het rechtstreeks gevolg is van de ten onrechte geweigerde vergunning. De gestelde schade is ontstaan doordat appellant de levering van de dieren illusoir heeft gemaakt door (voortijdig) van de koop af te zien."

In dit kader is een regelmatig voorkomende casus dat een werknemer door de bevoegde uitkeringsinstantie niet geschikt wordt geacht de gestelde arbeid te verrichten. ${ }^{\mathbf{1 4 9}}$ Dit bestuursorgaan keurt de werknemer af en kent hem een uitkering toe. De werkgever geeft gehoor aan het overheidsbesluit door de werknemer geen arbeid meer te laten verrichten en de loonbetaling te stoppen. De werknemer is het echter niet eens met het besluit van de uitkeringsinstantie. Hij is van mening is dat hij wel arbeidsgeschikt is. Ook is hij werkwillig. In de rechterlijke procedure blijkt achteraf dat de werknemer inderdaad ten onrechte ongeschikt is bevonden voor zijn werk. Volgens de Centrale Raad van Beroep kan de door de werknemer geleden inkomensschade niet worden toegerekend aan het vernietigde besluit, omdat de schade vooral voortvloeit uit de omstandigheid dat de werkgever niet het volledige loon heeft doorbetaald: 


\begin{abstract}
"Voorts wijst de Raad erop dat - naar hij, onder meer in zijn hiervoor genoemde uitspraak van 7 april 1999, vaker heeft overwogen - in een geval als dit de gevorderde vermogensschade vooral voortvloeit uit de omstandigheid dat de werkgever niet het - volledige - loon heeft doorbetaald."150
\end{abstract}

In de omstandigheid dat de werkgever zich bij zijn besluit om het loon niet door te betalen heeft verlaten op het overheidsbesluit ziet de Raad onvoldoende grond voor het oordeel dat de inkomensschade dient te worden toegerekend aan het onrechtmatige besluit. De Raad acht hierbij van doorslaggevend belang dat het vernietigde besluit naar zijn aard en strekking slechts ziet op de aanspraak op uitkeringen. In verband hiermee ziet de Raad niet in waarom aan dat besluit relevante betekenis toekomt voor de financiële gevolgen van door appellant en zijn werkgever in het kader van hun arbeidsrechtelijke relatie genomen beslissingen:

"In die arbeidsrechtelijke relatie komen aan appellante en haar werkgever eigen verantwoordelijkheden toe met betrekking tot de voor hen bestaande rechten en verplichtingen."151

In één van de genoemde uitspraken verwijst de Centrale Raad ter ondersteuning van zijn oordeel naar het arrest van de Hoge Raad in de parallelle loonvorderingszaak..$^{\mathbf{1 5 2}}$ In dit arrest laat de Hoge Raad het risico van het onjuiste arbeidsongeschiktheidsoordeel van de uitkeringsinstantie voor rekening van de werkgever komen. Dit oordeel vormt volgens de Centrale Raad ondersteuning voor zijn zienswijze dat de gestelde schade niet zozeer moet worden toegerekend aan het onjuiste besluit, maar aan de beslissing van de werkgever om de werknemer niet tot het werk toe te laten en het loon niet langer te betalen. Hiermee ben ik het niet eens. In de civiele zaak ging het er ingevolge artikel 7:628 BW om of de werknemer de overeengekomen arbeid niet heeft verricht door een oorzaak die in redelijkheid voor rekening van de werkgever behoort te komen. In die procedure was het bestuursorgaan, dat het onrechtmatige besluit had genomen, geen partij. Het oordeel van de Hoge Raad heeft naar mijn mening alleen betekenis in de verhouding werkgever/werknemer en houdt slechts in dat de schadeoorzaak van het onjuiste besluit niet voor rekening van de werknemer, maar voor rekening van de werkgever, dient te komen. Dit is iets anders dan de vraag of de schade kan worden toegerekend in de zin van 6:98 BW en het zegt naar mijn mening niets over aansprakelijkheid van de uitkeringinstantie voor het onrechtmatige besluit. Ook Kortmann wijst erop dat deze redenering van de Centrale Raad van Beroep niet sluitend is, omdat het Burgerlijk Wetboek hoofdelijke aansprakelijkheid kent. ${ }^{\mathbf{1 5 3}}$ Het is dus goed mogelijk dat zowel de werkgever als de uitkeringsinstantie jegens de werknemer aansprakelijk zijn voor de schade. Bovendien neemt de Centrale Raad ook geen aansprakelijkheid van de uitkeringsinstantie aan voor onjuiste arbeids(on)geschiktheidsoordelen als de werknemer zijn schade niet op werkgever kan verhalen. ${ }^{\mathbf{1 5 4}}$

Van Maanen noemt de motivering van de Centrale Raad van Beroep in deze uitspraak een 'gekunstelde redenering', die haaks staat op de civielrechtelijke dogmatiek inzake causaal verband. ${ }^{\mathbf{1 5 5}}$ Het is volgens hem vanzelfsprekend dat de afkeuring en de daarop volgende uitkering tot gevolg hebben dat de 
werkgever stopt met loondoorbetaling. Van Maanen is van mening dat er dan geen enkele ruimte meer is voor de werkgever om zich anders op te stellen, omdat hij niet gehouden is om aan de werknemer tegen de formeel vastgelegde opvatting van deskundigen in loon door te betalen en de werknemer eventueel zelfs aan het werk te zetten. Dit laatste zou naar zijn mening tot forse schadeclaims kunnen leiden als de gezondheidstoestand van de werknemer als gevolg daarvan verergert. Van Maanen ziet de risicoaansprakelijkheid voor vernietigde besluiten als reden voor dergelijke gekunstelde redeneringen met betrekking tot het causaal verband. Dit geldt volgens hem met name in de situaties waarin het bestuursorgaan niet onzorgvuldig jegens de benadeelde heeft gehandeld. Het gevolg hiervan is dat de bestuursrechter zich soms in bochten moet wringen om in gevallen waarin hij schadevergoeding niet redelijk acht de vordering toch af te wijzen ondanks de vaststaande onrechtmatigheid. Van Maanen meent dat de gekunstelde en over gesimplificeerde 'causaal verband ontbreekt' redeneringen hieraan te wijten zijn. Als oplossing stelt hij voor om af te stappen van het automatisme dat de vernietiging van een besluit tevens de onrechtmatigheid daarvan betekent en in plaats daarvan uit te gaan van een weerlegbaar vermoeden van onrechtmatigheid..$^{\mathbf{1 5 6}}$

Smits kan zich als privatist niet aan de indruk onttrekken dat achter het afwezig achten van causaal verband in de uitspraken over het onjuiste arbeidsongeschiktheidsoordeel een hele gedachtewereld schuil gaat die in de uitspraken niet expliciet wordt gemaakt en dat de motivering van de Centrale Raad niet uitdrukt wat dit college redengevend acht voor zijn oordeel. Dit vindt hij jammer. Vanuit puur privaatrechtelijk oogpunt is er volgens hem namelijk weinig op tegen om in dergelijke zaken wel causaal verband aan te nemen. Hij wijst erop dat zelfs voldaan is aan de eis van voorzienbaarheid, omdat voorzienbaar was dat intrekking van de uitkering zou leiden tot de schade. Het verzoek tot schadevergoeding dan toch afwijzen is naar zijn mening wel mogelijk, maar dan toch niet met een beroep op afwezigheid van causaal verband: dat rekt de spankracht van die eis teveel op. ${ }^{\mathbf{1 5 7}}$

In tegenstelling tot deze jurisprudentie heeft de Centrale Raad bij onjuiste arbeidsongeschiktheidsoordelen wel causaal verband aangenomen in zaken waarin omgekeerd de werknemer ten onrechte arbeidsgeschikt werd verklaard, terwijl hij zelf aangaf niet tot werken in staat te zijn. De schadeclaim wordt in die uitspraken niet afgewezen met het argument dat geen causaal verband bestaat omdat de schade vooral wordt veroorzaakt door de beslissing van de werkgever om de werknemer te laten werken en niet door het onjuiste besluit.

Dit is bijvoorbeeld het geval in een zaak waarin een kantoorleider van een bank zijn werk had moeten staken vanwege een blaascarcinoom. ${ }^{\mathbf{1 5 8}} \mathrm{Na}$ een intensieve behandeling van chemotherapie en bestralingen ging hij weer gedeeltelijk aan het werk. Op een gegeven moment moest hij van de uitkeringsinstantie weer voltijds aan de slag, terwijl hij aangaf dit niet aan te kunnen wegens vermoeidheidsklachten. Hij probeert zijn baan weer volledig te hervatten, maar valt uit. De uitkeringsinstantie weigert echter zijn uitkering te verhogen. Ook zijn werkgever geeft hem te kennen dat hij weer voltijds moet gaan werken. De werknemer probeert dit tot tweemaal toe, maar valt beide keren uit wegens spanningsklachten. Een psychiater constateert een ernstige depressie en een angststoornis. Naar het oordeel van de Centrale Raad is aannemelijk dat het psychisch letsel van de werknemer is veroorzaakt door samenlopende oorzaken, te weten het zich niet erkend voelen in de medische grondslag van zijn klachten 
door de uitkeringsinstantie en later ook door zijn werkgever. De Centrale Raad sluit in deze uitspraak aan bij de hoofdelijke aansprakelijkheid van artikel 6:102 lid 1 BW:

"In een geval waarin dezelfde schade is ontstaan door een samenloop van oorzaken, zijn volgens het civiele recht op grond van artikel 6:102, eerste lid van het BW de voor dezelfde schade aansprakelijke personen hoofdelijk voor het geheel aansprakelijk. De onderlinge bijdrage aan de schade kan vervolgens een rol spelen in het kader van de onderlinge bijdrageplicht."

De uitkeringsinstantie voert nog aan dat de psychische schade mede het gevolg is geweest van persoonlijke verliezen dan wel omstandigheden van de betrokkene en dat daarom de schade niet aan hem kan worden toegerekend. De Raad gaat daar niet in mee:

\begin{abstract}
"Ten aanzien van het standpunt van appellant (de uitkeringsinstantie, $L D B$ ) dat de schade mede het gevolg is geweest van de persoonlijke verliezen van gedaagde dan wel andere bijzondere omstandigheden [...]overweegt de Raad dat bij een onrechtmatige daad die bestaat in het toebrengen van letsel, de gevolgen van een door de persoonlijke predispositie van het slachtoffer bepaalde reactie op die daad in het algemeen als een gevolg van de onrechtmatige daad aan de dader moeten worden toegerekend. Dit zou anders zijn in het geval van bijzondere omstandigheden waarvan de Raad niet is gebleken."
\end{abstract}

In deze uitspraak speelt derhalve ook een rol de vraag welke invloed de persoonlijke predispositie van de benadeelde heeft op het toerekeningsoordeel. Volgens de Hoge Raad zullen bij een onrechtmatige daad die bestaat uit het toebrengen van letsel de gevolgen van een door de persoonlijke predispositie van het slachtoffer bepaalde reactie op die daad in het algemeen als een gevolg van de onrechtmatige daad aan de dader moeten worden toegerekend ook al zijn die gevolgen daardoor ernstiger en langer van duur dan in de normale lijn der verwachtingen ligt. ${ }^{\mathbf{1 5 9}} \mathrm{Bij}$ een onrechtmatige daad die niet bestaat in het toebrengen van letsel lijkt het van de geschonden norm en de concrete omstandigheden van het geval af te hangen of een dergelijke ruime toerekening plaatsvindt. ${ }^{\mathbf{1 6 0}}$ De Centrale Raad van Beroep lijkt aansluiting te zoeken bij deze rechtspraak. Hij bepaalt dat bij een onrechtmatige daad die bestaat in het toebrengen van letsel, de gevolgen van een door de persoonlijke predispositie van het slachtoffer bepaalde reactie op die daad in het algemeen als een gevolg van de onrechtmatige daad aan de dader moeten worden toegerekend. ${ }^{\mathbf{1 6 1}} \mathrm{Het}$ is opvallend dat het in deze zaak ging om een onrechtmatig besluit van de uitkeringsinstantie waarin een werknemer ten onrechte arbeidsgeschikt wordt verklaard en daardoor psychisch letsel opliep. Blijkbaar moet dit volgens de Raad worden gezien als een onrechtmatige daad, die bestaat in het toebrengen van letsel.

Ook in een andere uitspraak, waarin het ging om een werknemer die ten onrechte arbeidsgeschikt werd geacht en daardoor psychisch letsel opliep en inkomensschade leed, heeft de Centrale Raad toerekening daarvan aan de uitkeringsinstantie aangenomen. ${ }^{\mathbf{1 6 2}}$ De werknemer heeft meerdere keren geprobeerd weer (voltijds) aan het werk te gaan, maar valt steeds uit. In beroep 
tegen de arbeidsgeschiktheidbesluiten heeft de rechtbank zich laten adviseren door onafhankelijke deskundige artsen. De artsen menen dat betrokkene onterecht arbeidsgeschikt is verklaard. In één van de deskundigenrapporten wordt overwogen dat het erop lijkt dat de beslissing om hem arbeidsgeschikt te verklaren niet alleen onterecht was, maar een sterke verslechtering heeft gegeven van het functioneren van betrokkene. Volgens dit rapport is het nog maar de vraag of deze verslechtering te herstellen is. Op grond van de deskundigenverklaringen heeft de uitkeringsinstantie betrokkene alsnog volledig arbeidsongeschikt verklaard.

Hij vraagt daarom vergoeding van de geleden materiële en immateriële schade. Voor zijn conclusie dat deze schade aan het bestuursorgaan kan worden toegerekend in de zin van artikel 6:98 BW acht de Raad van belang dat, gelet op de persoonlijkheidsstructuur van betrokkene en het feit dat als hij niet aan het werk ging hij geen inkomen meer zou ontvangen, het voor de uitkeringsinstantie redelijkerwijs was te voorzien dat betrokkene weer volledig aan het werk zou gaan, ook al achtte hij zichzelf daartoe niet in staat. Uit verschillende deskundigenrapporten blijkt volgens de Raad dat het psychisch letsel het gevolg is van de onrechtmatige besluiten. Uit deze rapporten leidt de Raad af dat de betreffende besluiten niet verantwoord waren. Dit betekent naar de mening van de Raad dat het bestuursorgaan een voorzienbaar risico op hernieuwde uitval op zich heeft genomen. Voor zijn conclusie dat in dit geval is voldaan aan het vereiste van toerekening lijkt de Raad dus in ieder geval van belang te vinden dat de schade voorzienbaar was. Ook overweegt de Raad:

\footnotetext{
"Op grond van de in de voorgaande overwegingen genoemde omstandigheden komt de Raad, met name gelet op de aard en strekking van het vernietigde besluit en op de aard van de schade, tot de conclusie dat er een zodanig verband is tussen de gevorderde schadeposten en het onrechtmatige besluit, dat deze schade aan de gedaagde moet worden toegerekend."
}

Ook de aard en strekking van het besluit en de aard van de schade spelen dus een rol in het toerekeningsoordeel van de Raad. Met 'aard van de schade' zou het erom kunnen gaan dat sprake is van (psychische) letselschade, hoewel ook inkomensschade wordt gevorderd. Met betrekking tot de aard en de strekking van het besluit merkt de Raad nog op dat deze factoren weliswaar van belang zijn bij beantwoording van de toerekeningsvraag, maar er niet steeds toe leiden dat in dergelijke zaken geen sprake is van causaal verband. Dit hangt volgens de Raad af van de omstandigheden van het concrete geval.

Deze overweging sluit aan bij de multi-factor benadering van het vereiste van toerekening in het civiele recht.

Zoals gezegd wijst de Centrale Raad van Beroep de schadevordering in deze twee zaken in ieder geval niet af met het argument dat de schade niet wordt veroorzaakt door het vernietigde besluit, maar door de beslissing van de werkgever om de werknemer te laten werken. Ook de aard en strekking van het vernietigde besluit leiden niet tot afwijzing van de schadevordering. Het feit dat het (mede) gaat om (het toebrengen van) letselschade lijkt in beide uitspraken een rol te spelen bij de conclusie dat de schade kan worden toegerekend. In de tweede zaak wordt daarbij ook gewicht toegekend aan de voorzienbaarheid van de schade en de aard en strekking van het vernietigde besluit. Uit de uitspraak blijkt niet welke betekenis aan deze laatste factor 
toekomt. Een nadere toelichting hieromtrent zou naar mijn mening gewenst zijn. Dit geldt te meer nu we hiervoor hebben gezien dat de aard en strekking van dergelijke besluiten in de omgekeerde situatie voor de Centrale Raad juist de doorslaggevende reden is om de vordering af te wijzen.

Schlössels meent in zijn noot bij deze uitspraak ook dat het gaat om een ernstiger zorgvuldigheidsgebrek aan de zijde van de uitkeringsinstantie dan in de zaken waarin een werknemer ten onrechte arbeidsongeschikt wordt geacht.

\section{Ad b}

Betrokkene zit in de bijstand en krijgt op grond van een re-integratietraject een arbeidsverplichting opgelegd. ${ }^{\mathbf{1 6 3}} \mathrm{Zij}$ weigert een aangeboden baan, waarop zij voor een maand voor 100\% wordt gekort op haar uitkering. Later krijgt zij opnieuw een baan aangeboden bij IJmond Groen voor het verrichten van werkzaamheden als kantinemedewerkster voor de duur van 32 uur per week. Deze neemt zij aan, maar meldt zich de eerste dag ziek. De volgende dag wordt zij voor ongeveer twee weken opgenomen in verband met psychische klachten. Later wordt het bezwaar tegen het besluit waarop betrokkene voor een maand voor $100 \%$ wordt gekort op haar uitkering alsnog gegrond verklaard. Hierbij verwijst het bestuursorgaan naar een rapportage arbeidsonderzoek en geeft aan dat daaruit blijkt dat de arbeidsmogelijkheden van betrokkene beperkt lijken te zijn als gevolg van vermoeidheidsproblemen en psychosociale problemen. De rechtbank vernietigt ook de beslissing op bezwaar waarbij het bezwaar tegen het opleggen van de arbeidsverplichting ongegrond is verklaard. Hij wijst echter het verzoek tot vergoeding van immateriële schade af, omdat appellante onvoldoende heeft aangetoond dat de door haar geleden schade is veroorzaakt door het besluit om haar de arbeidsverplichting op te leggen.

In hoger beroep voert appellante daartegen aan dat zij niet in staat was te werken en dat al had aangegeven voordat zij met haar werk was begonnen. Door het korten van haar uitkering met $100 \%$ voor een maand voelde zij zich gedwongen aan het werk te gaan. Naar de mening van appellante is het causale verband tussen de ontstane psychische klachten in verband waarmee zij is opgenomen en de opgelegde maatregel evident. De Raad begint zijn overwegingen met betrekking tot het causaal verband door aan te sluiten bij artikel 6:98 BW:

\footnotetext{
"Volgens vaste jurisprudentie van de Raad is voor vergoeding van schade vereist dat de gestelde schade verband houdt met het onrechtmatige besluit en voorts dat alleen die schadeposten voor vergoeding in aanmerking komen die in een zodanig verband staan met dat besluit dat zij het bestuursorgaan, mede gezien de aard van de aansprakelijkheid (en) van de schade, als een gevolg van dat besluit kunnen worden toegerekend. Bij de beoordeling of toegerekend moet worden acht de Raad ook de aard en strekking van het onrechtmatige besluit een relevante factor."
}

De Centrale Raad komt tot het oordeel dat het causaal verband ontbreekt. De Raad stelt vast dat appellante ter toelichting op haar verzoek om schadevergoeding heeft aangegeven dat de causale relatie tussen het gestelde geestelijk letsel en de niet gehandhaafde maatregel kan worden afgeleid uit de chronologische volgorde van het opleggen van deze maatregel, het verrichten 
van de werkzaamheden en haar ziekenhuisopname. Op basis van deze toelichting is het vereiste causale verband volgens de Raad onvoldoende aangetoond:

\begin{abstract}
"Een nadere onderbouwing zou daarvoor noodzakelijk zijn geweest, te meer nu namens appellante eveneens is gesteld dat reeds sprake was van psychische klachten voorafgaand aan het besluit [...], waarbij is aangegeven dat op haar de arbeidsverplichting van toepassing is. Gebleken is voorts dat aan appellante al op 13 juli 2006 en op 14 juli 2006 antidepressiva zijn voorgeschreven, hetgeen er op wijst dat haar psychische klachten reeds vóór de indiensttreding bij IJmond Groen aanwezig en tot uiting gekomen waren."
\end{abstract}

Het gaat er dus om dat volgens de Raad het causale verband niet voldoende is aangetoond. Hiermee geeft de Raad eigenlijk te kennen er niet van overtuigt te zijn dat de schade feitelijk is veroorzaakt door het onrechtmatige besluit. Daarbij speelt volgens hem een rol dat de psychische klachten al aanwezig en tot uiting gekomen waren voor de indiensttreding. De laatste geciteerde overweging gaat mijns inziens derhalve niet zozeer over het vereiste van toerekening, maar ziet op het ontbreken van een condicio sine qua non verband. ${ }^{\mathbf{1 6 4}}$ Vertragingsschade bij de bouw van vakantiebungalows wordt volgens de Afdeling niet veroorzaakt door het vernietigde besluit, maar heeft de benadeelde aan zichzelf te wijten. ${ }^{\mathbf{1 6 5}}$ Een eigenaar van een bungalowpark wil dit park graag uitbreiden. Hij kan 31 huisjes laten bijbouwen, maar wil meer. Dit zou kunnen als de bestemming 'verblijfsrecreatie' zou worden gegeven aan een 15 meter brede strook. In eerste instantie keuren Gedeputeerde Staten het betreffende bestemmingsplan geheel goed, maar deze goedkeuring wordt op formele gronden vernietigd. Vervolgens beslissen zij opnieuw. Deze beslissing wordt door de Afdeling vernietigd voor zover goedkeuring was onthouden aan de bestemming 'verblijfsrecreatie' van de 15 meter brede strook. Uiteindelijk krijgt een strook van vijf meter breed wel deze bestemming; aan de overige strook van 10 meter onthouden Gedeputeerde Staten hun goedkeuring. Hierdoor kan de eigenaar van het bungalowpark zijn park met 33 huisjes uitbreiden. Hij stelt door de gang van zaken (vertragings)schade te lijden bij de voorgenomen uitbreiding van zijn bungalowpark. De Afdeling wijst zijn verzoek om vergoeding van de vertragingsschade af. Zij legt hieraan ten grondslag dat de eigenaar van het perceel ook na de vernietiging van het besluit tot onthouding van de goedkeuring aan de bestemming 'verblijfsrecreatie' voor de 15 meter brede strook de mogelijkheid had om zijn bungalowpark uit te breiden met 31 huisjes, maar dit niet heeft geëffectueerd door het aanvragen van een bouwvergunning en het opstellen van een verkavelingsplan, waarin het ook mogelijk zou zijn om ruimte te laten voor extra huisjes voor het geval dat door het definitieve besluit nog extra bouwmogelijkheden zouden ontstaan. Ook neemt de Afdeling mee dat niet is gebleken van een ondernemingsplan waarin de voorgenomen uitbreiding van het bungalowpark is opgenomen. De conclusie:

"Nu appellant geen pogingen heeft ondernomen om de bouwmogelijkheden die hij na het besluit van 10 april 1995 redelijkerwijs had te realiseren, kan de schade die appellant stelt te hebben geleden door het niet eerder verwezenlijken van zijn bouwplannen naar het oordeel van de Afdeling niet worden toegerekend aan dat besluit." 


\section{Combinatie $a \& b$}

In het volgende voorbeeld gaat het om een appellante, die volledig rolstoelgebonden is. ${ }^{\mathbf{1 6 6}} \mathrm{Zij}$ is als telefoniste/informatrice in dienst getreden bij haar werkgever en naderhand bevorderd tot manager. Met ingang van haar dienstverband heeft zij van de uitkeringsinstantie een volledige taxivergoeding voor het woon/werkverkeer toegekend gekregen. Na een aantal jaren trekt het bestuursorgaan de taxivergoeding in. Appellante heeft geprobeerd met het openbaar vervoer naar haar werk te gaan, maar dit bleek niet haalbaar. Daarop heeft de werkgever vrijwillig en uitdrukkelijk onder voorbehoud van tijdelijkheid besloten de kosten van het woon/werkverkeer per taxi voorlopig voor zijn rekening te nemen. Op een gegeven moment geeft de werkgever aan dat hij wil stoppen met de vrijwillige taxivergoeding. Appellante reageert daarop door aan te geven dat zij dan haar werk niet meer zou kunnen bereiken. Voor de werkgever is deze situatie aanleiding geweest om het voornemen kenbaar te maken de arbeidsovereenkomst te ontbinden. Nog voor de ontbinding kent de uitkeringsinstantie in een nieuw besluit aan appellante echter alsnog de taxivergoeding toe en de werkgever ziet daarom af van het voorgenomen ontslag. Ook komt vast te staan dat de taxivergoeding nooit had mogen worden ingetrokken en de uitkeringsinstantie erkent de onrechtmatigheid van dit besluit. Appellante heeft vervolgens getracht schadevergoeding te krijgen. De uitkeringsinstantie heeft een deel van de gevraagde schade toegekend, maar weigert een vergoeding voor inkomensschade ten gevolge van een gebroken carrièreopbouw en voor immateriële schade. Met betrekking tot de inkomensschade voert appellante in de procedure bij de Centrale Raad van Beroep aan dat indien aanstonds de juiste voorziening woon/werkverkeer zou zijn toegekend geen carrièrebreuk was opgetreden. De Raad is van mening dat de gestelde schade niet in zodanig verband staat met het onrechtmatige besluit dat deze het bestuursorgaan, mede gezien de aard van de aansprakelijkheid en van de schade als een gevolg van dat besluit kan worden toegerekend. Bij de beoordeling of toegerekend moet worden acht de Raad de aard en de strekking van het onrechtmatige besluit een relevante factor. De Raad is van mening dat causaal verband ontbreekt:

\footnotetext{
"Dienaangaande is de Raad, op grond van de in dit geding ter beschikking staande gegevens van oordeel dat de door appellante met een carrièrebreuk in verband gebrachte gestelde inkomensschade vooral voortvloeit uit de omstandigheid dat de werkgever eind 1993/begin 1994 voornemens is geweest om de met appellante bestaande dienstbetrekking per 1 april 1994 door middel van ontbinding te beëindigen. Dit voornemen vond zijn oorzaak in een samenstel van factoren, namelijk enerzijds in de beslissing van die werkgever om de door hem vrijwillig, uitdrukkelijk ten titel van tijdelijkheid uitbetaalde taxivergoeding niet langer te continueren en anderzijds in het feit dat appellante jegens hem te kennen had gegeven dat zij in dat geval niet langer in staat was om haar werk te bereiken."
}

Ad c

Een andere omstandigheid is aan de orde in een zaak, waarin de uitkeringsinstantie in eerste instantie besloot geen ziekengeld toe te kennen, omdat de betrokkene niet arbeidsongeschikt zou zijn. ${ }^{\mathbf{1 6} 7}$ De rechtbank vernietigt 
dit besluit echter. Hierdoor heeft de benadeelde over de periode van het onrechtmatige besluit alsnog recht op ziekengeld. Ingevolge zijn CAO zou dit bedrag door zijn voormalige werkgever worden aangevuld tot 100\% van het loon. Zijn voormalige werkgever is echter voor de uitspraak van de rechtbank failliet gegaan. Benadeelde vordert van de uitkeringsinstantie vergoeding van het misgelopen loon. Hij stelt zich hierbij op het standpunt dat, indien in eerste instantie een juist besluit was genomen, zijn werkgever nog niet failliet was geweest en hij de aanvulling op het loon zonder meer zou hebben ontvangen. Deze stelling van appellant is erop gericht het condicio sine qua non verband aan te tonen: zonder het onrechtmatige besluit zou de schade niet zijn geleden. De Raad reageert daarop echter alsof het de toerekeningsvraag betreft:

\begin{abstract}
"Aldus vindt deze schade niet zozeer zijn oorsprong in de onjuiste beslissing, maar in het feit dat de werkgever geen verhaal biedt voor zijn achteraf gebleken verplichtingen. Ook de Raad is van oordeel dat dit door appellant geleden nadeel niet in zodanig verband staat met het door de rechtbank vernietigde besluit dat dit, mede gezien de aard van de aansprakelijkheid en de aard van vorenomschreven schade als een gevolg van dat besluit aan gedaagde kan worden toegerekend."
\end{abstract}

In de laatste uitspraak gaat het om een coffeeshop. De uitspraak zelf geeft over de feiten niet veel bloot, maar volgens de annotator blijkt uit de stukken dat appellanten zich met succes hadden beklaagt over de vergunningverlening ten behoeve van een coffeeshop in hun omgeving. Daarnaast verzochten appellanten om bestuursdwang tot te passen. De handhaving werd onrechtmatig geweigerd. Op grond van deze twee onrechtmatige besluiten vorderden appellanten schadevergoeding in verband met, zover hier van belang, vermindering van hun woongenot vanwege permanente overlast. De gemeente nam wel aan dat het woon- en leefklimaat in de omgeving van de coffeeshop werd aangetast, maar pas nadat een andere coffeeshop in de gemeente door brand werd gesloten. Hierdoor kreeg de coffeeshop in de buurt van appellanten meer klandizie. Appellanten krijgen hun schade niet vergoed. De vermindering van het woongenot is volgens de Afdeling niet veroorzaakt door de onrechtmatige besluiten:

"[...] dat, voor zover vanaf medio januari 1998 als gevolg van de sluiting van een andere coffeeshop en de daarmee gepaard gaande toename van de klandizie van coffeeshop $X$ wel sprake is geweest van een relevante vermindering van het woongenot van appellanten, deze niet is veroorzaakt door het door de burgemeester gehandhaafde besluit tot verlening van de exploitatievergunning, nu dat besluit door de rechtbank bij uitspraak van 29 juli 1997 is herroepen. $\mathrm{Zij}$ is evenzeer terecht tot de slotsom gekomen dat de schade evenmin is veroorzaakt door de weigering van burgemeester en wethouders om bestuursdwang toe te passen en dat ook het niet tijdig nemen van een nieuwe beslissing op het bezwaar daaromtrent in dit geval niet leidt tot een verplichting tot schadevergoeding voor burgemeester en wethouders."168

De exploitatievergunning voor de coffeeshop was al herroepen voordat de schade werd geleden en kon om die reden niet de oorzaak van de schade zijn. Met betrekking tot de weigering tot handhaving heeft de Afdeling niet expliciet 
gemotiveerd waarom de schade hierdoor naar haar mening niet is veroorzaakt. Blijkens de noot is de redenering dat dit besluit dateerde van voor de brand en de coffeeshop voor de brand van de andere coffeeshop het woon- en leefklimaat niet aantastte; een weigering om bestuurdwang toe te passen kan dan volgens de annotator niet de oorzaak van de vermindering van het woongenot zijn. Het lijkt erop dat de Afdeling niet het niet handhaven, maar de brand in de andere coffeeshop als oorzaak van de schade ziet, hoewel zij dit niet expliciet overweegt. Het condicio sine qua non verband lijkt mij evenwel aanwezig: als de gemeente rechtmatig had gehandeld en bestuursdwang had toegepast, was de coffeeshop er niet meer geweest en was er, brand of geen brand, geen overlast geweest.

\section{Literatuur}

Van Maanen en Schlössels wijzen er ook op dat bestuursrechters met regelmaat causaal verband ontkennen tussen onrechtmatige besluiten en schade op grond van het feit dat de schade niet het gevolg is van onrechtmatig handelen van het bestuur, maar van handelen of nalaten van gelaedeerde zelf of andere oorzaken kent. Tevens wordt volgens hen de strenge eis van 'direct' of 'voorzienbaar' gevolg gesteld. ${ }^{169}$

Schlössels stelt in dit kader de vraag in hoeverre een onrechtmatig besluit kan gelden als schadeoorzaak, omdat een besluit in beginsel slechts leidt tot een wijziging of een (nadere) vaststelling van de rechtspositie van burgers en daardoor hun gedrag beïnvloedt. ${ }^{\mathbf{1 7 0}}$ De schade is volgens Schlössels dan ook in eerste instantie het gevolg van een doen of nalaten van burgers in reactie op het onrechtmatige besluit: er is dus steeds sprake van een complexe, samengestelde causaliteitsketen. Hij meent dat het gaat om beantwoording van de vraag of door het publiekrechtelijk rechtshandelen de kans op het ontstaan van de schade is vergroot. ${ }^{\mathbf{1 7 1}}$ Naar civielrechtelijke maatstaven beschouwd dient de causaliteit naar zijn mening op grond van artikel 6:98 BW te worden vastgesteld aan de hand van een op basis van redelijkheidsmaatstaven gecorrigeerde voorzienbaarheidsleer. Deze leer omvat volgens hem mede een (geobjectiveerde) waarschijnlijkheidscomponent. Hierbij komt de vraag aan de orde wat van de gemiddelde burger in reactie op publieke besluitvorming, gegeven de omstandigheden, mag worden verwacht. ${ }^{\mathbf{1 7 2}} \mathrm{Nu}$ schade door een vernietigd besluit zoals gezegd het gevolg is van een keten van oorzaken meent Schlössels dat het aan de schadevergoedingsrechter is om te komen tot een toerekening van de schade naar redelijkheid aan één of aan verschillende oorzaken. In het laatste geval kan er volgens hem sprake zijn van een draaglastverdeling, waarbij de toepassing van concepten als 'eigen schuld' en 'risicoaanvaarding' een rol speelt. Naar de mening van Schlössels worstelt de bestuursrechtspraak met het probleem van de samengestelde schadeoorzaken. Het resultaat hiervan is zijns inziens vaak weinig genuanceerd (in die zin dat de bestuursrechter het onrechtmatige besluit meestal niet als schadeoorzaak aanwijst, zo begrijp ik). ${ }^{\mathbf{1 7 3}}$ Bestuursrechters tonen volgens hem vaak niet veel iniatieven om complexe relaties tussen onrechtmatige besluitvorming en handelen van burgers in reactie daarop te ontrafelen. Het uitgangspunt dat een onrechtmatig besluit het gedrag van burgers steeds gegeven de specifieke omstandigheden van het geval beïnvloedt blijft daarom bij de bepaling van het causaal verband vaak onderbelicht. ${ }^{\mathbf{1 7 4}}$

Naar de opvatting van Schlössels zorgt dit ervoor dat het gedrag van burgers op 
basis van simpele 'causa proxima' benaderingen als enige oorzaak van de schade wordt aangewezen, terwijl deze naar maatstaven van redelijkheid minimaal mede geacht moet worden te zijn veroorzaakt door het onrechtmatige besluit. ${ }^{\mathbf{1 7 5}}$ Hij noemt dit het wegschaven van overheidsaansprakelijkheid. ${ }^{\mathbf{1 7 6}}$ Reden hiervoor kan zijn dat de bestuursrechter een te vergaande overheidsaansprakelijkheid wil voorkomen. ${ }^{\mathbf{1 7 7}}$

Volgens Tak wordt de schade door de bestuursrechters zeer vaak op dubieuze gronden aangemerkt als een gevolg van een andere gebeurtenis dan het onrechtmatige besluit. ${ }^{\mathbf{1 7}} \mathbf{8}$

Jurgens is van mening dat bij gebrekkige handhaving het niet optreden van de overheid 'slechts' een secundaire factor is in de causaliteitsketen. De overtreder is primair aansprakelijk. Deze situatie zou daarom volgens haar niet op een lijn mogen worden gezet met die waarin meerdere daders zelfstandige onrechtmatige daden plegen. Op grond van de aard van de aansprakelijkheid en van de schade (artikel 6:98 BW) of omstandigheden van het geval zou in dergelijke gevallen slechts een beperkte aansprakelijkheid van de overheid gerechtvaardigd zijn. ${ }^{179}$

\section{Beoordeling en conclusie}

De bestuursrechter wijst dus regelmatig schadevorderingen af, omdat de schade volgens hem wordt veroorzaakt door andere omstandigheden dan het onrechtmatige besluit. De Centrale Raad van Beroep koppelt deze motivering aan het toerekeningsvereiste van artikel 6:98 BW: de schade staat niet in een zodanig verband tot het onrechtmatige besluit dat zij aan het bestuursorgaan dat dat besluit heeft genomen, mede gezien de aard van de aansprakelijkheid en van de schade, als een gevolg van dat besluit kan worden toegerekend. In de uitspraken van de Afdeling bestuursrechtspraak van de Raad van State wordt deze koppeling niet gemaakt en blijft in het midden of de conclusie dat de schade is veroorzaakt door andere omstandigheden dan het onrechtmatige besluit volgens de Afdeling een antwoord is op de feitelijke vraag of de schade al dan niet door het onrechtmatige besluit is veroorzaakt of op de rechtsvraag op grond van welke objectieve criteria de schade wel of niet dient te worden toegerekend. ${ }^{\mathbf{1 8 0}}$ In de betreffende bestuursrechtelijke uitspraken is het condicio sine qua non verband tussen de schade en het vernietigde besluit wel steeds aanwezig. ${ }^{\mathbf{1 8 1}}$ Naar mijn mening wijkt deze rechtspraak af van de toepassing van het causaliteitsvereiste van de civiele rechter bij feitelijke handelingen. Als het condicio sine qua non verband vaststaat, is het feit dat dezelfde schade mede wordt veroorzaakt door andere omstandigheden dan de betreffende onrechtmatige feitelijke handeling voor de Hoge Raad namelijk op zichzelf geen reden om de schadevordering op die grond (geheel) af te wijzen, ook niet als het gaat om overheidsaansprakelijkheid. ${ }^{\mathbf{1 8 2}} \mathrm{Bij}$ meerdere aansprakelijke personen voor dezelfde schade bestaat op grond van artikel 6:102 BW daarvoor hoofdelijke aansprakelijkheid. Als de schade een gevolg is van een omstandigheid die aan de benadeelde kan worden toegerekend, dan wordt de vergoedingsplicht van de aansprakelijke persoon ingevolge artikel 6:101 BW verminderd door de schade over hem en de benadeelde te verdelen in evenredigheid met de mate waarin de aan ieder toe te rekenen omstandigheden tot de schade hebben bijdragen, tenzij uit de billijkheid anders voortvloeit. Bij meerdere schadeoorzaken lijkt de Hoge Raad in recente jurisprudentie 
bovendien in sommige gevallen de mogelijkheid van proportionele aansprakelijkheid te aanvaarden. ${ }^{\mathbf{1 8 3}}$ Dit houdt in dat een bepaald percentage van de schade door de normschender wordt vergoed naar rato van waarschijnlijkheid dat hij de schade heeft veroorzaakt.

Als in de civiele rechtspraak eenmaal een condicio sine qua non verband is vastgesteld, komt vervolgens de rechtsvraag aan de orde of de schade op grond van artikel 6:98 BW op basis van objectieve factoren, in onderlinge verhouding bezien, kan worden toegerekend. Het feit dat er meerdere schadeoorzaken en/of schadeveroorzakers voor dezelfde schade bestaan, leidt er dan niet toe dat de schadevordering alleen om die reden niet aan de betreffende onrechtmatige daad kan worden toegerekend en daarom geheel wordt afgewezen. In de besproken bestuursrechtelijke rechtspraak is dit wel het geval.

Één van Brunners deelregels van toerekening luidt dat naarmate het schadelijke gevolg minder ver verwijderd is van de gebeurtenis waarop de aansprakelijkheid berust, toerekening eerder gerechtvaardigd is. Het is mogelijk dat de bestuursrechter met zijn overweging dat geen causaal verband bestaat, omdat de schade is veroorzaakt door andere omstandigheden dan het onrechtmatige besluit, wil aansluiten bij deze deelregel. ${ }^{\mathbf{1 8 4}}$ Dit kan worden afgeleid uit de bewoordingen in sommige uitspraken dat de schade geen 'voorzienbaar en onontkoombaar'185 of 'rechtstreeks ${ }^{\mathbf{1 8 6}}$ gevolg is van het onrechtmatige besluit. Mocht de bestuursrechter inderdaad van mening zijn dat de gevorderde schade in een te ver verwijderd verband staat tot het onrechtmatige besluit om daaraan te kunnen worden toegerekend, dan zou hij er mijns inziens goed aan doen om dit duidelijker in de motivering van de uitspraak tot uitdrukking te brengen. Dit dekt de lading beter en sluit in ieder geval qua bewoordingen aan bij het civiele schadevergoedingsrecht.

Overigens legt de Hoge Raad, indien het condicio sine qua non verband vaststaat, de bewijslast van de stelling dat de schade in een te ver verwijderd verband staat tot de onrechtmatige daad om daaraan te worden toegerekend op degene die zich daarop beroept, zijnde de verweerder tegen de schadevordering. ${ }^{\mathbf{1 8} 7}$ Mocht de bestuursrechter in dergelijke gevallen deze bewijsregel overnemen, dan betekent dat dus dat de overheid aannemelijk dient te maken dat de schade niet kan worden toegerekend aan het onrechtmatige besluit, omdat het in een te ver verwijderd verband daarmee staat. Echter: ook als de besproken uitspraken van de bestuursrechter worden gezien in het licht van de verwijderdheid tussen de schade en het onrechtmatige besluit bestaat naar mijn mening verschil tussen deze bestuursrechtspraak en de toepassing door de civiele rechter van de toerekeningsregel dat schade die in een te ver verwijderd verband staat tot de onrechtmatige daad daaraan niet kan worden toegerekend. Verwijderdheid tussen schade en onrechtmatige daad is in het civiele recht zelden een argument om de schadevordering af te wijzen. ${ }^{\mathbf{1 8 8}} \mathrm{De}$ voorzienbaarheid van de schade speelt in de civiele jurisprudentie een prominentere rol bij beantwoording van de toerekeningsvraag. In de rechtspraak van de bestuursrechter, waarin geen causaal verband wordt aangenomen omdat de schade zou zijn veroorzaakt door omstandigheden die a) voortvloeien uit de inhoud van het onrechtmatige besluit of daar nauw mee samenhangen, lijkt echter het enkele feit dat er tussen de onrechtmatige daad van de overheid en de schade nog een extra 'daad' staat steeds voldoende reden om de schadevordering af te wijzen.

Dit leidt er naar mijn mening toe dat de bestuursrechter schadevorderingen 
afwijst, omdat deze volgens hem niet voldoen aan het toerekeningsvereiste, terwijl de schade naar 'civiele' maatstaven in ieder geval niet in een te ver verwijderd verband staat tot de onrechtmatige daad: als bijvoorbeeld een uitkeringsorgaan een werknemer onterecht afkeurt en hij inkomensschade leidt, omdat zijn werkgever hem op grond van het afkeuringsbesluit ontslaat, staat deze schade mijns inziens civielrechtelijk gezien niet in een te ver verwijderd verband met de onrechtmatige daad van de overheid om daaraan te kunnen worden toegerekend. ${ }^{\mathbf{1 8 9}}$ Dit geldt mijns inziens ook voor de causale verwijderdheid tussen een ten onrechte verschuldigde premie inzake werknemersverzekeringswetten en het besluit van een organisatie om op basis van deze kosten dan maar minder werknemers in dienst te nemen ${ }^{\mathbf{1 9 0}}$, de verwijderdheid tussen niet handhaven en schade ontstaan door de niet gehandhaafde illegale activiteit ${ }^{\mathbf{1 9 1}}$ en het onrechtmatig geen vergunning toekennen om bepaalde goederen en/of dieren te importeren en daardoor geleden gederfde winst ${ }^{\mathbf{1 9 2}}$ etc.

De vraag is wat de reden voor dit verschil kan zijn. De bestuursrechter geeft in een aantal uitspraken aan dat bij zijn beslissing de aard en strekking van het vernietigde besluit een rol speelt. Deze toerekeningsfactor zal in paragraaf 6.2.3. aan bod komen. De literatuur noemt het corrigeren van de strenge 'pseudorisicoaansprakelijkheid' voor vernietigde besluiten en beperking van de overheidsaansprakelijkheid in het algemeen als mogelijke reden voor de strikte toepassing van het causaliteitsvereiste bij besluitenaansprakelijkheid.

Schlössels wijst er ook op dat bij besluitenaansprakelijkheid steeds sprake is van een samengestelde causaliteitsketen. ${ }^{193}$

Dit is in de onderhavige zaken inderdaad het geval. In de betreffende uitspraken over besluitenaansprakelijkheid wordt de schade veroorzaakt doordat de burger handelt op basis van de onjuiste inhoud van het besluit. Deze extra 'schakel' tussen de onrechtmatige daad en de schade is in die zin kenmerkend voor dergelijke besluiten. $\mathrm{Nu}$ is deze omstandigheid voor de bestuursrechter reden om de schadeclaim geheel af te wijzen. Wat mij betreft doet dit onvoldoende recht aan het feit dat de onrechtmatige handelingen van de overheid feitelijk wel degelijk in meer of mindere mate hebben bijgedragen aan het ontstaan van de schade. ${ }^{194}$ Toch wil de bestuursrechter deze schade blijkbaar niet juridisch toe rekenen. Een genuanceerdere benadering zou zijn om in dergelijke gevallen een proportionele aansprakelijkheid van de overheid aan te nemen. Hierdoor kan worden bewerkstelligd dat de overheid in ieder geval een gedeelte van de schade dient te vergoeden. Vaststelling van het percentage van aansprakelijkheid zie ik vervolgens als volgt. Verplicht het vernietigde besluit tot bepaalde handelingen of geeft het nauwelijks ruimte om anders te handelen dan is gedaan dan lijkt mij een hoog percentage van aansprakelijkheid gerechtvaardigd. Het percentage kan ook 100\% zijn Het onrechtmatige besluit is in dat geval immers de belangrijkste schadeoorzaak. Dit is mijns inziens aan de orde in de uitspraken over de onjuiste arbeidsongeschiktheidsoordelen. ${ }^{\mathbf{1 9 5}}$ Als een uitkeringsinstantie oordeelt dat een werknemer arbeidsongeschikt is en hij om die reden een uitkering ontvangt, is het naar mijn mening niet reëel om te stellen dat de werkgever ruimte heeft om zijn eigen afweging hieromtrent te maken. Het is vanzelfsprekend dat hij dan de werknemer niet meer laat werken en de loonbetaling stopt. ${ }^{\mathbf{1 9 6}} \mathrm{De}$ uitkeringsinstantie wordt immers geacht deskundig op dit gebied te zijn. Het levert bovendien een onwerkbare situatie op als de werkgever in afwijking van het besluit de werknemer zou verplichten om ondanks zijn afkeuring toch door 
te werken.

Een lager percentage aansprakelijkheid is gerechtvaardigd als het onrechtmatige besluit geen handelingen verplicht stelt, dan wel logischerwijs tot gevolg heeft, en de burger veel vrijheid laat. In dat geval zijn immers de gemaakte keuzes en handelingen van de burger substantiëlere schadeoorzaken en is de rol van de overheid beperkter. Dit geldt bijvoorbeeld voor de inhoud van een overeenkomst, die is gebaseerd op het onjuiste overheidsbesluit. ${ }^{197}$ Het percentage van de aansprakelijkheid van de overheid zou dus mijns inziens moeten aansluiten bij de mate waarin het onrechtmatige besluit al dan geen keuzevrijheid tot handelen dan wel nalaten laat en zal zich bewegen tussen de twee beschreven uitersten. Het voorgestelde criterium haakt aan bij de voorzienbaarheid van de schade. Hierbij speelt ook een rol de vraag wat van de gemiddelde burger in reactie op publieke besluitvorming, gegeven de omstandigheden, mag worden verwacht. ${ }^{198}$ Een goede motivering van het gekozen percentage is noodzakelijk om de gedachtegang van het bestuursorgaan inzichtelijk te maken en de uitspraak overtuigingskracht te geven.

Bij besluitenaansprakelijkheid voor gebrekkige handhaving of gebrekkig toezicht zou wat mij betreft een laag percentage van overheidsaansprakelijkheid passen. ${ }^{199}$ In die gevallen is immers, meer dan bij de hiervoor bedoelde zaken waarin op basis van de inhoud van een onjuist besluit is gehandeld, de overtreding de primaire oorzaak van de schade. Het niet optreden van de overheid is 'slechts' een secundaire schadeoorzaak. ${ }^{\mathbf{2 0 o}}$

Proportionele aansprakelijkheid wordt doorgaans gekoppeld aan causaliteitsonzekerheid. ${ }^{\mathbf{2 0 1}}$ Hiervan is in de besproken zaken over besluitenaansprakelijkheid geen sprake. Ook los van onzeker causaal verband is naar mijn mening een proportionele aansprakelijkheid echter goed mogelijk. ${ }^{\mathbf{2 0 2}}$ Voor bijna alle besproken zaken geldt dat, hoewel wel meerdere oorzaken voor de schade bestaan, hiervoor naast de overheid geen derde partij civielrechtelijk aansprakelijk is. Het oordeel over de proportionele aansprakelijkheid van het bestuursorgaan is dan dus het enige rechterlijke oordeel over de kwestie en levert geen problemen met andere partijen op. Dit ligt anders bij onrechtmatige besluiten met betrekking tot handhaving of toezicht. In die zaken is meestal een aansprakelijke civiele partij betrokken. Het is dan lastig voor de bestuursrechter om proportionele aansprakelijkheid van de overheid aan te nemen, omdat dit in strijd kan komen met een eventueel (later) vonnis van de civiele rechter over deze aansprakelijkheid. In dergelijke gevallen zou de bestuursrechter de schadeclaim kunnen verwijzen naar de civiele rechter. Overigens zal deze situatie niet vaak voorkomen. Een aanzienlijk deel van de claims wegens falend toezicht of gebrekkige handhaving betreft immers feitelijk handelen. Ook zal een (groot) deel van de benadeelden direct voor beide claims bij de burgerlijke rechter aankloppen. Hoewel een reëel aandachtspunt, dient dit obstakel dus ook niet overdreven te worden.

Als beide claims aan de burgerlijke rechter worden voorgelegd, dan heeft hij twee mogelijkheden. Volgens het systeem van het BW zou hij in deze situatie hoofdelijke aansprakelijkheid moeten aannemen. In de regresprocedure tussen de overheid en de aansprakelijke civiele partij komt dan tot uiting dat de overheid naar rato van schuld voor een bepaald percentage aansprakelijk is. In de praktijk zal de benadeelde er waarschijnlijk vaak voor kiezen om de overheid aan te spreken vanwege de diepe zakken. Regres is vervolgens niet altijd realistisch. Het risico bestaat dat de overheid dan relatief vaak voor alle schade 
opdraait. Dit kan wringen, zeker als de bijdrage van de overheid aan het ontstaan van de schade in werkelijkheid relatief klein is. De burgerlijke rechter zou er in dergelijke zaken daarom ook voor kunnen kiezen om een proportionele aansprakelijkheid en een schadevergoedingsplicht naar rato aan te nemen. Dit voorkomt dat de overheid steeds voor alle schade opdraait.

In de andere twee 'categorieën' van de besproken bestuursrechtelijke jurisprudentie worden de schadevorderingen afgewezen, omdat de schade zou zijn veroorzaakt door b) omstandigheden die bij de benadeelden zelf liggen dan wel c) overige omstandigheden. Ook hier bestaat mijns inziens een onderscheid met de civielrechtelijke jurisprudentie over feitelijke handelingen. Is de afwijzing van de schadevordering gebaseerd op het oordeel dat de schade feitelijk niet is veroorzaakt door het onrechtmatige besluit, dan stoelt de afwijzing van de schadeclaim volgens mij in werkelijkheid op het ontbreken van het condicio sine qua non verband en is het geen toerekeningsoordeel. ${ }^{203}$

Als het condicio sine qua non verband wel vaststaat en het dus gaat om de toerekeningsvraag, wordt in het 'civiele' aansprakelijkheidsrecht de schadevordering niet zonder meer geheel afgewezen omdat naast de onrechtmatige daad ook omstandigheden aan de zijde van de benadeelde of andere omstandigheden hebben bijgedragen aan het ontstaan van de schade. Wel wordt de schade ingevolge artikel 6:101 BW naar rato verdeeld tussen degene, die aansprakelijk is uit onrechtmatige daad, en de betreffende benadeelde indien de schade mede een gevolg is van een omstandigheid die aan de benadeelde kan worden toegerekend. Ik zie geen reden waarom dit anders zou moeten zijn in het geval van aansprakelijkheid voor onrechtmatige besluiten. ${ }^{\mathbf{2 0 4}}$ Het ligt mijns inziens dan ook voor de hand om in de betreffende zaken aan te sluiten bij artikel 6:101 BW. ${ }^{\mathbf{2 0 5}}$

\title{
6.2.3 Aard en strekking van het besluit als toerekeningsfactor
}

Jurisprudentie

In de jurisprudentie van de Centrale Raad van Beroep worden regelmatig de aard en strekking van het vernietigde besluit genoemd als factoren, die een rol spelen bij beantwoording van de vraag of de schade al dan niet kan worden toegerekend. De standaardoverweging luidt:

\begin{abstract}
"Volgens vaste jurisprudentie van de Raad is voor vergoeding van schade vereist dat de gestelde schade verband houdt met het onrechtmatige besluit en voorts dat alleen die schadeposten voor vergoeding in aanmerking komen die in een zodanig verband staan met dat besluit dat zij het bestuursorgaan, mede gezien de aard van de aansprakelijkheid (en) van de schade, als een gevolg van dat besluit kunnen worden toegerekend. Bij de beoordeling of toegerekend moet worden acht de Raad ook de aard en strekking van het onrechtmatige besluit een relevante factor."
\end{abstract}

In de meeste uitspraken wordt echter naast de laatste zin van de overweging verder niets opgemerkt over de aard en strekking van het besluit, zodat niet duidelijk wordt welke invloed de aard en strekking van het vernietigde besluit hebben op het toerekeningsoordeel van de Raad in het concrete geval. ${ }^{\mathbf{2 o 6}}$ In de reeds besproken uitspraken over de onjuiste 
arbeidsongeschiktheidsoordelen gaat de Raad wel nader in op de rol van de aard en strekking van het vernietigde besluit als toerekeningsfactor.

In de situatie waarin de werknemer inkomensschade lijdt, omdat hij door de uitkeringsinstantie ten onrechte arbeidsongeschikt wordt verklaard, bestaat volgens de Centrale Raad geen causaal verband tussen dit oordeel en de schade. De schade wordt volgens de Centrale Raad niet veroorzaakt door het onjuiste besluit, maar vloeit vooral voort uit de omstandigheid dat de werkgever niet het volledige loon heeft doorbetaald. ${ }^{\mathbf{2 0}}$ In de omstandigheid dat de werkgever zich hierbij heeft laten leiden door het onjuiste arbeidsongeschiktheidsoordeel van de uitkeringsinstantie ziet de Raad onvoldoende grond gelegen voor het oordeel dat de gevolgen daarvan dienen te worden toegerekend aan het vernietigde besluit. Aard en strekking van het besluit acht de Raad voor dit oordeel steeds van doorslaggevend belang:

\begin{abstract}
"Hierbij acht de raad van doorslaggevende betekenis dat het vernietigde besluit naar zijn aard en strekking slechts ziet op appellantes aanspraak op uitkeringen krachtens de AAW en WAO jegens gedaagde. De Raad vermag dan ook niet in te zien waarom aan dat besluit relevante betekenis toekomt voor de - ( financiële) gevolgen van - door appellante en haar werkgever in het kader van hun arbeidsrechterlijke relatie genomen beslissingen. In die arbeidsrechtelijke relatie komen aan appellante en haar werkgever eigen verantwoordelijkheden toe met betrekking tot de voor hen bestaande rechten en verplichtingen. "208
\end{abstract}

Aard en strekking van het besluit leiden bij onjuiste arbeidsongeschiktheidsoordelen niet per definitie tot de conclusie dat causaal verband ontbreekt. ${ }^{209} \mathrm{Bij}$ het onjuiste oordeel, dat een werknemer arbeidsgeschikt is en hij hierdoor psychisch letsel opliep, heeft de Centrale Raad wel toerekening van de schade aan de uitkeringsinstantie aangenomen. De werknemer vorderde vergoeding van inkomensschade en immateriële schade. De Raad vindt de aard en strekking van het vernietigde besluit in dergelijke zaken weliswaar een relevante factor bij beantwoording van de toerekeningsvraag, maar niet de enige. Bovendien leiden aard en strekking van het besluit er niet toe dat nooit sprake is van causaal verband. Dit hangt af van de omstandigheden van het geval:

\begin{abstract}
"In deze uitspraak ligt derhalve niet het oordeel van de Raad besloten dat enkel de aard en strekking van een besluit over (de intrekking van) een arbeidsongeschiktheidsuitkering er steeds toe leiden dat geen sprake is van een toereikend causaal verband wanneer schade aan de orde is die verband houdt met een door het uitvoeringsorgaan overgenomen - nadien onjuist gebleken - oordeel van een verzekeringsarts en/of een arbeidsdeskundige over de (mate van) arbeidsongeschiktheid van een werknemer/verzekerde. Of daarvan sprake is, hangt - zoals uit even vermelde uitspraak blijkt - af van de omstandigheden van het concrete geval."210
\end{abstract}

In deze zaak speelde aard en strekking van het onrechtmatige besluit een belangrijke rol voor het oordeel van de Raad dat wel causaal verband bestond:

“De arbeidsongeschiktheidswetgeving strekt ertoe personen die ten gevolge 
van ziekte of gebrek geen of minder inkomsten uit arbeid kunnen verwerven, een inkomensvervangende uitkering te verstrekken. Indien een werknemer, zoals appellant, weer volledig geschikt wordt verklaard voor het verrichten van zijn eigen werk, dient deze zijn werk in het kader van zijn dienstbetrekking in beginsel weer volledig te hervatten teneinde van inkomsten uit of in verband met arbeid verzekerd te blijven."

Bij de beslissing dat in deze zaak was voldaan aan het vereiste van toerekening speelden, naast de aard en strekking van het besluit, ook de voorzienbaarheid en de aard van de schade een rol.

\section{Literatuur}

Het criterium van de Centrale Raad van Beroep dat bij beantwoording van de toerekeningsvraag ook de aard en de strekking van het vernietigde besluit een relevante factor zijn, wordt ook in de literatuur besproken. Auteurs zijn van mening dat de Centrale Raad hier een koppeling maakt met de relativiteitsleer van artikel 6:163 BW. Kortmann wijst erop dat het oordeel van de Centrale Raad in deze zaken een opvatting is over de reikwijdte van een wettelijke norm en dus een relativiteitsoordeel. Hiervan uitgaande schiet de motivering van de uitspraak naar zijn mening tekort, omdat een oordeel dat relativiteit ontbreekt gemotiveerd dient te worden aan de hand van een aantal factoren die de beschermingsomvang van een norm bepalen: de wettekst, wetsgeschiedenis, wetssystematiek en de verkeersopvattingen ter zake. ${ }^{\mathbf{2 1 1}}$

Volgens Van Rossum en De Witte-van den Haak blijkt uit de zaken over de vraag of bij onjuiste oordelen over de arbeidsgeschiktheid van een werknemer de uitkeringsinstantie al dan niet aansprakelijk is duidelijk dat de eis van causaal verband in bestuursrechtelijke zaken anders kan uitpakken dan in civielrechtelijke zaken. Zij menen dat de burgerlijke rechter hier vrijwel zeker wel causaal verband zou hebben aangenomen. Zij wijzen erop dat in deze zaken voldaan is aan het condicio sine qua non vereiste, maar dat de Centrale Raad dit niet voldoende acht met verwijzing naar de aard en strekking van het vernietigde besluit. Aard en strekking van het besluit kunnen volgens hen ook niet op iets anders zien dan op de toekenning van uitkeringsaanspraken door het bestuursorgaan aan burgers. Net als Kortmann vinden ook Van Rossum en De Witte-van den Haak dat het meewegen van de aard en strekking van het vernietigde besluit doet denken aan de relativiteitseis van artikel 6:163 BW. Het oordeel van de Centrale Raad komt er volgens hen op neer dat de geschonden norm slechts betrekking heeft op een aanspraak op uitkering en dus niet strekt ter bescherming tegen schade bestaande uit loonderving. Zij zijn van mening dat dit oordeel weinig met causaal verband te maken heeft, terwijl de Raad zijn oordeel wel stoelt op het ontbreken van causaal verband. Hoewel het criterium van de aard en strekking van een besluit ervoor kan zorgen dat de rechter schade uitsluit die in een te ver verwijderd verband staat met het onrechtmatige besluit, kan dit naar hun mening ook worden bereikt door toepassing van artikel 6:98 BW. Zij zijn zelf overigens van mening dat in de onderhavige gevallen van onjuiste arbeidsongeschiktheidsoordelen geen sprake is van een te ver verwijderd verband. Van Rossum en De Witte-van den Haak concluderen dat een ambtenaar met betrekking tot het vaststellen van causaal verband beter af is bij de burgerlijke rechter. ${ }^{\mathbf{2 1 2}}$ 
Ook Schlössels meent dat met de verwijzing naar aard en strekking van het vernietigde besluit de Centrale Raad van Beroep toepassing geeft aan de relativiteitsleer. Volgens Schlössels lijkt het erop dat het bestuursrecht een koppeling maakt tussen causaliteit en relativiteit. Deze leer is in het civiele recht echter verworpen. Schlössels stelt de vraag of, en zo ja in hoeverre, het bestuursrechtelijke aansprakelijkheidsrecht in dit verband terecht afwijkt van het civiele recht. ${ }^{\mathbf{2 1 3}}$

Schueler en Van Ettekoven schrijven uitgebreid over de betreffende jurisprudentie van de Centrale Raad van Beroep met betrekking tot de onjuiste arbeids(on)geschiktheidsoordelen. Zij menen dat de Centrale Raad in deze uitspraken in feite oordeelt dat de gestelde schade in een te ver verwijderd verband staat tot het onrechtmatige besluit om aan het bestuursorgaan te kunnen worden toegerekend en in dat kader gewicht toekent aan het uitgangspunt dat een uitkeringsbesluit naar aard en strekking slechts ziet op de aanspraak op uitkering. De auteurs vragen zich af of de Raad hiermee een nieuwe factor heeft willen toevoegen aan de bekende afwegingsfactoren van Brunner. Schueler en Van Ettekoven wijzen erop dat bij hantering dit criterium de niet eenvoudig te beantwoorden vraag rijst op welke gevolgen een publiekrechtelijk besluit naar zijn aard en strekking is gericht. De hier te maken keuze raakt ook volgens Schueler en Van Ettekoven aan toepassing van de relativiteitsleer. Naar hun mening heeft de keuze een rechtspolitiek karakter. Zij raden aan om hier de criteria van Brunner toe te passen, maar benadrukken dat het mogelijk is dat de Centrale Raad van Beroep met toepassing van deze criteria tot dezelfde eindconclusie zou zijn gekomen over het antwoord op de vraag of de geclaimde schade kan worden toegerekend aan het onrechtmatige besluit als via het criterium van 'aard en strekking van het vernietigde besluit'. Hantering van de deelregels van Brunner biedt volgens hen echter de mogelijkheid de rechtspraak inzake toerekening te nuanceren en inzichtelijker te maken. ${ }^{\mathbf{2 1 4}}$ Schueler geeft aan dat de Centrale Raad van Beroep aan de afwegingsfactoren in het kader van de toerekening een nieuwe factor heeft toegevoegd door ook de aard en strekking van het vernietigde besluit van belang te achten. De gevolgen die feitelijk aan een besluit worden verbonden, voldoen niet aan het juridische causaliteitscriterium indien zij niet behoren tot de gevolgen waarop het besluit naar aard en strekking is gericht. Volgens Schueler wordt de causaliteitseis hierdoor wel erg beperkend toegepast in de uitspraken over aansprakelijkheid van de uitkeringsinstantie voor onjuiste arbeids(on)geschiktheidsoordelen. De beslissingen van de werkgever zijn vaak een voorzienbaar gevolg van het uitkeringsbesluit, zodat het naar zijn mening wel ver gaat om het causale verband zonder meer afwezig te achten. Een besluit is gericht op een bepaald rechtsgevolg, maar kan ook neveneffecten kan hebben. De vraag is volgens Schueler of deze neveneffecten als gevolg van het besluit aan het bestuursorgaan kunnen worden toegerekend. Hij concludeert dat de jurisprudentie ervoor lijkt te hebben gekozen om alleen de gevolgen waarop het besluit is gericht daaraan toe te rekenen in de zin van artikel 6:98 BW en neveneffecten niet. ${ }^{\mathbf{2 1 5}}$

\section{Beoordeling en conclusie}

De Centrale Raad van Beroep laat bij beantwoording van de toerekeningsvraag 'de aard en de strekking van het vernietigde besluit' meewegen als toerekeningsfactor. De deelregels van causaliteit van Brunner kennen in het 
kader van de aard van de aansprakelijkheid belang toe aan beschermingsdoelen strekking, alsmede beschermingsomvang van de geschonden norm. ${ }^{\mathbf{2 1 6}}$ Naar mijn mening sluit de betreffende jurisprudentie van de Centrale Raad daarbij aan. ${ }^{\mathbf{2 1 7}}$ Ik vind derhalve niet dat de Centrale Raad hierdoor causaliteit en relativiteit verwart. Wel hebben beide onderwerpen mijns inziens te maken dezelfde soort juridische vragen en aspecten, zodat zij elkaar op dit punt zullen raken.

Het valt mij op dat de Centrale Raad van Beroep meestal niet duidelijk maakt welke invloed de aard en strekking van het vernietigde besluit hebben op het toerekeningsoordeel in het concrete geval. Hierdoor bieden de uitspraken geen inzicht in de gedachtegang van de Centrale Raad omtrent de toerekening. Door in het concrete geval aan te geven welke betekenis en welk gewicht hij toekent aan de aard en strekking van het vernietigde besluit zou de Raad naar mijn mening zijn toerekeningsoordelen begrijpelijker en inzichtelijker maken. In de uitspraken waarin de werknemer inkomensschade lijdt, omdat hij door de uitkeringsinstantie ten onrechte arbeidsongeschikt wordt verklaard, geeft de Raad wel duidelijk de rol en betekenis van de aard en strekking van het vernietigde besluit als toerekeningsfactor aan. Bij zijn oordeel dat in dit geval geen causaal verband bestaat, acht hij van doorslaggevende betekenis dat het vernietigde besluit naar zijn aard en strekking slechts ziet op een aanspraak op uitkeringen krachtens de AAW en WAO.

Het oordeel van de Raad lijkt erop neer te komen dat alleen toerekenbaar is de schade, die voortvloeit uit de aanspraak op een uitkering, omdat dit het rechtsgevolg is waarop het besluit is gericht. ${ }^{\mathbf{2 1 8}}$ Dit betekent dat in deze gevallen alleen zogenaamde 'directe' schade voor vergoeding in aanmerking komt. Een dergelijke vergaande beperking van de omvang van de schadevergoedingsverplichting komt naar mijn weten op andere terreinen van het aansprakelijkheidsrecht niet voor. Gevolgschade komt als regel wel voor vergoeding in aanmerking, tenzij het in een te ver verwijderd verband staat tot de onrechtmatige daad. Uit de motivering van de Centrale Raad blijkt mij ook niet waarom hij deze afwijking nodig, dan wel gerechtvaardigd, acht. De inkomensschade van de werknemer is mijns inziens zeer goed te voorzien is en staat in ieder geval naar 'civiele' maatstaven niet in een te ver verwijderd verband met het onjuiste keuringsbesluit. ${ }^{\mathbf{2 1 9}} \mathrm{Mij}$ lijkt dat voor deze afwijking van de gebruikelijke toepassing van artikel 6:98 BW, waardoor zo een vergaande beperking van de omvang van de schadevergoedingsplicht ontstaat, een nadere verklaring op zijn plaats is. Dit geldt te meer nu de Centrale Raad in zijn uitspraken aangeeft aan te sluiten bij het civiele schadevergoedingsrecht en artikel 6:98 BW. Ik begrijp niet waarom aard en strekking van juist deze besluiten tot de genoemde conclusie leiden. Met andere woorden: naar mijn mening kan de motivering van de uitspraken de beslissing tot het ontbreken van causaliteit niet dragen. Ik zie ook niet direct een reden voor de vergaande beperking, behalve misschien de algemene wens om de overheidsaansprakelijkheid te beperken. ${ }^{220}$

Overigens heeft de Centrale Raad wel aansprakelijkheid van de uitkeringsinstantie aangenomen in de omgekeerde situatie dat een werknemer ten onrechte arbeidsgeschikt was verklaard en daardoor schade leed. Aard en strekking van het besluit leiden bij onjuiste arbeids(on)geschiktheidsoordelen dus niet altijd tot de conclusie dat causaal verband ontbreekt. Dit hangt volgens de Raad af van de omstandigheden van het concrete geval. ${ }^{\mathbf{2 2 1}}$ 
De vraag blijft welke rol de aard en de strekking van het vernietigde besluit in het algemeen spelen bij het toerekeningsoordeel. Een algemene beperking tot vergoeding van de schade, die voortvloeit uit de rechtsgevolgen waarop het vernietigde besluit is gericht, zou betekenen dat bij besluitenaansprakelijkheid alleen nog directe schade voor vergoeding in aanmerking komt. Zelf vind ik dat door te bepalen dat alleen directe schade voor vergoeding in aanmerking komt het causaliteitsvereiste zonder goede - juridische - reden te nauw zou worden genomen.

\subsubsection{Geen toepassing deelregels toerekening Brunner}

Jurisprudentie

In paragraaf 6.2.2. bleek dat de bestuursrechter regelmatig schadevorderingen afwijst omdat de schade volgens hem wordt veroorzaakt door andere omstandigheden dan het vernietigde besluit. In paragraaf 6.2.3. kwam aan de orde dat de Centrale Raad van Beroep de aard en strekking van het vernietigde besluit als toerekeningsfactoren hanteert.

Het valt op dat in de bestuursrechtelijke jurisprudentie over het vereiste van toerekening de (overige) toerekeningsfactoren van Brunner nauwelijks een rol spelen. Er is in het overgrote deel van de uitspraken geen sprake van een multifactor benadering. De bestuursrechter beoordeelt in het algemeen niet of aan de hand van al deze factoren, in onderlinge verhouding bezien, voldaan is aan het vereiste van toerekening.

Vaak motiveert de bestuursrechter ook niet uitdrukkelijk op grond van welke omstandigheden hij tot zijn oordeel komt dat de schade al dan niet aan de onrechtmatige daad kan worden toegerekend. Hierdoor is het lastig te achterhalen welke factoren en omstandigheden hij van belang acht voor zijn toerekeningsoordeel.

De Centrale Raad van Beroep beantwoordt bijvoorbeeld de toerekeningsvraag ontkennend in een zaak waarin de benadeelde jegens de uitkeringsinstantie vergoeding vordert van de proceskosten, die hij heeft gemaakt in een procedure tegen zijn voormalige werkgever om zijn ontslag aan te vechten. ${ }^{\mathbf{2 2 2}} \mathrm{De}$ onderliggende feiten zijn als volgt. Nadat zijn arbeidsovereenkomst is beëindigd, vraagt de oud-werknemer een werkeloosheidsuitkering aan. Deze wordt door de uitkeringsinstantie geweigerd wegens verwijtbare werkenloosheid, omdat de voormalige werknemer akkoord is gegaan met zijn ontslag. Het bestuursorgaan is van mening dat als de werknemer dit niet had gedaan, hij nog in dienst had kunnen blijven bij zijn voormalige werkgever. De oud-werknemer roept daarop alsnog de nietigheid van zijn ontslag in en maakt tevens bezwaar tegen de weigering van zijn uitkering. In bezwaar handhaaft de uitkeringsinstantie de weigering, primair omdat betrokkene niet werkeloos is geworden nu hij als gevolg van het inroepen van de nietigheid van het ontslag recht op loondoorbetaling heeft en subsidiair omdat hij verwijtbaar werkloos is geworden. Vervolgens dagvaart de oud-werknemer zijn voormalige werkgever en vordert nietigheid van het aan hem verleende ontslag. Tevens vecht hij de beslissing op bezwaar aan. De bestuursrechter vernietigt de weigering tot verlening van de werkeloosheidsuitkering. De civiele rechter wijst daarna de vordering tot nietigheid van het ontslag tegen de voormalige werkgever af. De uitkeringsinstantie laat vervolgens zijn standpunt dat de werknemer verwijtbaar 
werkeloos is geworden varen en kent hem alsnog een uitkering toe. Dit gebeurt op basis van informatie van de werkgever dat hij een verzoek tot ontbinding van de arbeidsovereenkomst zou hebben ingediend indien zijn werknemer niet zou hebben ingestemd met de beëindiging van het dienstverband. De oudwerknemer vordert daarop schadevergoeding van de uitkeringsinstantie, bestaande uit kosten van achteraf onnodig gebleken civiele procedures tegen zijn voormalig werkgever. Het geding in hoger beroep beperkt zich tot de vraag of de schade die betrokkene heeft geleden als gevolg van de onrechtmatige besluiten aan de uitkeringsinstantie kan worden toegerekend. Dit is volgens de Raad niet het geval:

"hij onderschrijft het oordeel van de rechtbank dat het voeren van een civielrechtelijke procedure tegen de werkgever over de rechtmatigheid van het ontslag voor appellant niet noodzakelijk was om de besluiten van het Uwv waarbij hem een WW-uitkering is onthouden, te kunnen aanvechten, terwijl inhoud en strekking van die besluiten daartoe ook geen enkele aanleiding gaven."

Naast de aard en de strekking van het besluit speelt dus volgens de Centrale Raad ook een rol dat het voeren van de civielrechtelijke procedure niet noodzakelijk was om de besluiten te kunnen aanvechten.

Ook in de volgende zaak speelt de noodzakelijkheid c.q. vrijwilligheid van de gemaakte kosten een rol bij de vraag of deze kunnen worden toegerekend. Indien een werkgever door een onjuiste beslissing van de uitkeringsinstantie ten onrechte aan zijn werknemer loon doorbetaalt, komen alleen de volgens de wet of CAO verplichte betalingen voor vergoeding in aanmerking. Loon dat vrijwillig is betaald kan niet aan het onrechtmatige besluit worden toegerekend. Een werkgever heeft schade heeft geleden doordat de uitkeringsinstantie hem ten onrechte de verplichting had opgelegd het loon van een werknemer door te betalen wegens onvoldoende inspanning van de werkgever tot re-integratie van de werknemer. De werkgever had aan de werknemer 100\% van zijn loon doorbetaald, terwijl hij wettelijk maar verplicht was tot betaling van $70 \%$ van het loon. De Raad is om die reden van mening dat slechts 70\% van het als gevolg van het onrechtmatige besluit doorbetaalde loon aan de uitkeringsinstantie kan worden toegerekend. ${ }^{223}$

Een bijzondere redenering omtrent de toerekening wordt gevolgd in de navolgende zaak. Betrokkene ontvangt een nabestaandenuitkering. Als gevolg van een auto-ongeval raakt zij arbeidsongeschikt en krijgt zij een arbeidsongeschiktheidsuitkering. Om deze reden wordt zij door de betreffende uitkeringsinstantie gedeeltelijk gekort op haar nabestaandenuitkering. Later wordt haar nabestaandenuitkering nogmaals naar beneden bijgesteld. Het oorspronkelijke besluit was derhalve onjuist. Zij stelt schade te hebben geleden, doordat het onjuiste besluit ertoe heeft geleid dat zij bij de vaststellingsovereenkomst inzake de letselschade met betrekking tot het autoongeval een te laag bedrag is overeengekomen, omdat zij was uitgegaan van een te hoog bedrag van de nabestaandenuitkering. Volgens de Raad is niet voldaan aan het vereiste van toerekening:

"Evenals de rechtbank is de Raad van oordeel dat de door appellante gevorderde schade niet kan worden toegerekend aan het onrechtmatige 
besluit van 14 juni 2004. Daartoe overweegt de Raad dat appellante [...] door de Svb uitgebreid is geïnformeerd over de op haar van toepassing zijnde regelgeving, zodat het haar redelijkerwijs duidelijk had kunnen zijn dat het daarvan afwijkende besluit van 14 juni 2004 onjuist was en niet als uitgangspunt kon dienen voor de onderhandelingen met Achmea over de vergoeding van letselschade."224

Volgens de Raad is dus niet voldaan aan het toerekeningsvereiste, omdat de benadeelde had kunnen weten dat het besluit onjuist was, nu het bestuursorgaan haar eerder had gewezen op de van toepassing zijnde regelgeving. De Raad wijst het schadeverzoek derhalve af, omdat hij vind dat de schade aan de benadeelde zelf is te wijten. Deze overweging vind ik niet erg overtuigend. Voor hetzelfde geld waren immers de inlichtingen onjuist. Indien de Raad dergelijke schade niet voor vergoeding in aanmerking wil laten komen, zou hij dit naar mijn mening beter kunnen motiveren met de overweging dat de schade in dit geval te ver verwijderd is van de onrechtmatige daad.

Ten slotte bestaan ook uitspraken, waarin de conclusie dat niet is voldaan aan het toerekeningsvereiste, niet (expliciet) wordt toegelicht en blijkt ook uit de uitspraken zelf niet (impliciet) welke factoren bij dit oordeel een rol hebben gespeeld. ${ }^{225}$

\section{Literatuur}

Met betrekking tot de rechtspraak van de Centrale Raad van Beroep concluderen Schueler en Van Ettekoven dat de Centrale Raad nog moeite heeft met de invulling van de toerekening naar redelijkheid, omdat de uitkomsten betrekkelijk rigide, soms digitaal (alles of niets) zijn en niet zelden tot het oordeel leiden dat de gestelde schade niet aan het onrechtmatige besluit kan worden toegerekend. De auteurs vragen zich af of daarmee recht wordt gedaan aan de in het geding zijnde belangen van burgers die schade leiden door onrechtmatige overheidsbesluiten en of het niet beter kan, bijvoorbeeld door meer aansluiting te zoeken bij het burgerlijke recht en meer specifiek bij de benadering van Brunner. Het nut van de deelregels van causaliteit van Brunner is volgens Schueler en Van Ettekoven vooral dat beslissingen over toerekening er beter door kunnen worden gemotiveerd, waardoor ze ook beter controleerbaar worden. Het maakt de toerekening van schade doorzichtiger en beslissingen daarover kunnen rationeel worden verantwoord. Het systeem beoogt bovendien bij te dragen aan toerekeningsbeslissingen die als billijk worden ervaren, dat wil zeggen aansluiten bij hetgeen in de samenleving als rechtvaardig wordt ervaren. Het is de auteurs niet duidelijk waarom de Centrale Raad van Beroep een eigen causaliteitsleer zou moeten ontwikkelen. Naar hun mening zou aansluiting bij de civielrechtelijke leer van de redelijke toerekening op het terrein van de Raad heel goed mogelijk zijn en een heldere rechtsontwikkeling bevorderen. ${ }^{\mathbf{2 2 6}}$

Ook Kortmann, Van Maanen en Schlössels valt het op dat de criteria van Brunner nauwelijks lijken te spelen in de jurisprudentie van de Centrale Raad van Beroep over het causaal verband. ${ }^{\mathbf{2 2 7}}$ Van Maanen en Schlössels vinden dat er bij besluitenaansprakelijkheid meer aandacht zou moeten zijn voor de leer van de toerekening naar redelijkheid van art. 6:98 BW. Zij wijzen op de krampachtige en zuinige toepassing door bestuursrechters van deze leer. Volgens hen zou er systematisch aandacht moeten worden besteed aan een 
aanvaardbare invulling van het causaliteitsvereiste en moeten gekunstelde causaliteitsredeneringen worden voorkomen. Zij hebben de indruk dat de bestuursrechters maar wat doen om het bestuur te beschermen. ${ }^{\mathbf{2 2 8}}$

\section{Beoordeling en conclusie}

Met betrekking tot de toerekening lijkt in sommige zaken het feit dat de schade bestaat uit kosten, die niet noodzakelijkerwijs uit het onrechtmatige besluit voortvloeien, een factor te zijn bij het oordeel dat deze niet kan worden toegerekend. Vaak blijkt uit de uitspraak echter niet duidelijk op welke factoren het toerekeningsoordeel gebaseerd is. Opvallend vind ik dat de voorzienbaarheid van de schade en de aard van de schade bijna nooit worden genoemd in de toerekeningbeslissingen van de bestuursrechter, terwijl deze factoren in de rechtspraak over aansprakelijkheid van private partijen juist erg belangrijk zijn. In de huidige bestuursrechtspraak spelen dus, naast het feit dat de schade wordt veroorzaakt door andere omstandigheden dan het onrechtmatige besluit en de aard en strekking van het besluit, nauwelijks andere toerekeningsfactoren een rol.

Het zou wat mij betreft goed zijn als meer factoren (zichtbaar) van belang zouden worden bij het toerekeningsoordeel van de bestuursrechter. Door te differentiëren kan beter recht worden gedaan aan de omstandigheden van het concrete geval. Ik stel mij voor dat dit zal leiden tot genuanceerdere toerekeningsbeslissingen. Dit zal mijns inziens ook de acceptatie van de uitspraken ten goede kunnen komen.

Om dit te bewerkstelligen kan de bestuursrechter naar mijn mening het beste (meer) aansluiting zoeken bij de factoren van toerekening van Brunner. ${ }^{229}$ Op die manier heeft hij het voordeel van een bekend, bestendig en goed ontwikkeld stelsel. De toerekeningsfactoren van Brunner zijn bovendien goed bruikbaar bij besluitenaansprakelijkheid. Het is ook denkbaar dat het bestuursrecht, naast de factoren van Brunner, nog eigen toerekeningsfactoren ontwikkelt. Artikel 6:98 BW biedt die ruimte. Een belangrijke reden voor het invoeren van dit artikel was immers dat de rechter verplicht en ook in de gelegenheid is zijn beslissing te motiveren met de werkelijke overwegingen die daaraan ten grondslag liggen. Het toerekeningsvereiste lijkt mij daarom bij uitstek de plek om openlijk en kenbaar rekening te houden met het feit dat het gaat om aansprakelijkheid van de overheid en dus de bijzondere positie van de overheid in het aansprakelijkheidsrecht uitdrukkelijk mee te wegen.

\section{Doel van de geschonden norm}

Bij de vraag of toerekening in het concrete geval gerechtvaardigd is, dient steeds te worden gekeken naar beschermingsdoel- en strekking, alsmede naar beschermingsomvang van de geschonden norm. ${ }^{\mathbf{2 3 0}}$ Ook uit de rechtspraak blijkt dat bij de toerekeningsvraag de strekking van de geschonden norm een factor van belang kan zijn. ${ }^{\mathbf{2 3 1}}$

\section{Verkeers- en veiligheidsnormen}

Bij schending van een verkeers- of veiligheidsnorm wordt zeer ruim toegerekend. Bij overtreding van deze normen moet rekening worden gehouden met de mogelijkheid van ernstige gevolgen, hoe deze zich ook in het concrete 
geval mogen voordoen. ${ }^{\mathbf{2 3 2}}$ De ruime toerekening wordt gerechtvaardigd geacht doordat de strekking van deze normen is het voorkomen van ongevallen. ${ }^{\mathbf{2 3 3}}$

\section{Risico-aansprakelijkheid}

Tegenwoordig wordt wel aangenomen dat bij risicoaansprakelijkheid niet steeds een beperkte toerekening gerechtvaardigd is. Beslissend is de strekking van de geschonden norm. ${ }^{\mathbf{2 3 4}}$

Jurisprudentie

De bestuursrechter wijst in zaken van besluitenaansprakelijkheid de schadeclaim regelmatig af, omdat de schade volgens hem is veroorzaakt door andere omstandigheden dan het onrechtmatige besluit. Deze rechtspraak wordt vaak negatief beoordeeld. In sommige uitspraken van de Centrale Raad wordt de genoemde conclusie overigens gekoppeld aan de aard en strekking van het vernietigde besluit. Dit onderwerp komt in paragraaf 6.2.3. aan bod.

Ik vind de betreffende jurisprudentie opvallend. In zaken tussen civiele partijen speelt namelijk het feit dat ook andere schadeoorzaken bestaan geen (zichtbare) rol bij de toerekeningsvraag van artikel 6:98 BW. In het kader van dit artikel is het van belang het geconstateerde verschil te duiden en mogelijke redenen hiervoor te onderzoeken. Daartoe heb ik ten eerste de bedoelde uitspraken van de bestuursrechter nader bestudeerd.

De betreffende andere omstandigheden houden in dat de rechter meent dat de schade wordt veroorzaakt door a) omstandigheden die voortvloeien uit de inhoud van het onrechtmatige besluit of daarmee nauw samenhangen of $b$ ) omstandigheden die bij de benadeelden zelf liggen. In sommige uitspraken spelen nog c) overige omstandigheden een rol. Ook worden schadeclaims afgewezen wegens een combinatie van deze omstandigheden.

Ad a

De Koninklijke Luchtmacht heeft met bedrijf X een overeenkomst gesloten, die inhoudt dat X voor in Nederland gestationeerde F16 vliegtuigen het onderhoud zal verzorgen. ${ }^{\mathbf{2 3 5}}$ Daartoe worden met name in de Verenigde Staten technici geworven, die vervolgens worden uitgezonden naar Nederland. De monteurs hebben een arbeidsovereenkomst met X en zijn op detacheringsbasis werkzaam bij de Koninklijke Luchtmacht. Appellante in de schadevergoedingsprocedure treedt in Nederland op als agent van $\mathrm{X}$ en verzorgt namens $\mathrm{X}$ onder meer de praktische uitvoering van het contract met de Luchtmacht, waaronder begrepen de logistieke ondersteuning en de behartiging van andere praktische zaken van de Amerikaanse werknemers van X. Bij besluit van 16 september 1996 heeft De Raad van Bestuur van het Uwv zich op het standpunt gesteld dat appellante premies verschuldigd is ingevolge de sociale werknemersverzekeringswetten over de aan de hier te lande werkzame Amerikaanse F16 monteurs verrichte betalingen. Met deze premies was bij de vaststelling van de vergoeding die appellante van $\mathrm{X}$ ontving geen rekening gehouden. In reactie op dit besluit heeft de Luchtmacht besloten tot een minimale inzet van F16 monteurs, naar ik begrijp omdat zij bang was deze premies zelf te moeten voldoen. Appellante vecht het besluit aan. Het besluit wordt in eerste instantie gehandhaafd, maar in beroep door de rechtbank vernietigd. X vordert daarop o.a. schadevergoeding 
wegens gederfde winst van het Uwv, omdat de Luchtmacht op grond van het onrechtmatige besluit heeft besloten tot minimale inzet van F16 monteurs. De Centrale Raad sluit met betrekking tot het causaal verband aan bij de bewoordingen van artikel 6:98 BW en stelt dat, wil schade op grond van artikel 8:73 Awb voor vergoeding in aanmerking komen, deze in zodanig verband moet staan met het vernietigde besluit dat zij het bestuursorgaan, mede gezien de aard van de aansprakelijkheid en van de schade, als een gevolg van dat besluit kan worden toegerekend. Hierbij acht de Raad ook de aard en de strekking van het vernietigde besluit van belang. Vervolgens wijst de Raad het verzoek tot schadevergoeding af wegens ontbreken van causaal verband. De reden:

\begin{abstract}
"Vastgesteld moet worden dat de Klu met X had gecontracteerd over de inzet van Amerikaanse F16-monteurs hier te lande en daarnaast appellante met $\mathrm{X}$ had gecontracteerd over de logistieke ondersteuning van deze monteurs. De schade die appellante stelt te hebben geleden, is een uitvloeisel van de wijze waarop de Klu en $\mathrm{X}$ hun (contractuele) relatie naar aanleiding van de besluitvorming van gedaagde nader hebben ingevuld. Dat deze nadere invulling een voorzienbaar en onontkoombaar gevolg was van deze besluitvorming, acht de Raad met de rechtbank niet, althans onvoldoende aannemelijk gemaakt. Dit betekent dat er geen grond aanwezig is om de gestelde schade toe te rekenen aan de onrechtmatig genomen besluiten."
\end{abstract}

Een imkervereniging heeft in strijd met de bepalingen van het bestemmingsplan bijen op een perceel gehouden. ${ }^{\mathbf{2 3 6}}$ Omwonenden hebben het college van Burgemeester en Wethouders van Haarlemmermeer om handhaving verzocht. Het college heeft in strijd met de beginselplicht tot handhaving dit verzoek geweigerd. Pas nadat de Rechtbank de weigering tot handhaving heeft vernietigd, is het college tot handhaving overgegaan. Omwonenden verzoeken de gemeente vervolgens om vergoeding van schade, die zij stellen te hebben geleden als gevolg van het door de vereniging in strijd met de bepalingen van het bestemmingsplan houden van bijen. De schade bestaat o.a. uit gederfd woongenot. De vordering tot vergoeding van deze schade wordt afgewezen wegens het ontbreken van causaal verband. De Afdeling:

"De gestelde schade is veroorzaakt door het door de vereniging houden van
bijen ter plaatse."

Van Ravels vraagt zich in zijn noot bij deze uitspraak af hoe we deze overweging moeten duiden. Betekent dit dat de gestelde schade niet is veroorzaakt door het bestuursorgaan dat ten onrechte weigerde (tijdig) te handhaven? Of moeten we deze overweging zo begrijpen dat de omstandigheid dat een derde de primaire veroorzaker is van de schade een factor is die medebepalend is voor het antwoord op de vraag of de schade in redelijkheid kan worden toegerekend aan de weigering van het bestuursorgaan? Van Ravels denkt het laatste.

In de volgende zaak is ten onrechte geen vergunning toegekend voor het invoeren van 500 Vierteenlandschilpadden. ${ }^{\mathbf{2 3 7}}$ Het oorspronkelijke besluit tot weigering van de vergunning was gebaseerd op een onjuiste verordening. Hierop dient de importeur een verzoek tot schadevergoeding in. De schade bestaat volgens hem uit gederfde winst: hij is een geldelijke verplichting aangegaan, 
maar heeft de betreffende dieren niet kunnen afnemen, omdat de leverancier deze niet langer kosteloos in bewaring wilde houden tijdens de procedure tegen de weigering van de vergunning. De importeur stelt uiteindelijk van de koop te hebben afgezien om schade te beperken, ook omdat dergelijke procedures veelal lang duren. De Rechtbank is van mening dat causaal verband ontbreekt, nu de schade 'niet alleen' door het onrechtmatige besluit is veroorzaakt, maar vooral door de door de importeur gegeven toestemming aan de buitenlandse leverancier om de schildpadden te laten verkopen. De Afdeling is het hiermee eens:

"De Afdeling deelt de zienswijze van de rechtbank dat de gestelde schade niet het rechtstreeks gevolg is van de ten onrechte geweigerde vergunning. De gestelde schade is ontstaan doordat appellant de levering van de dieren illusoir heeft gemaakt door (voortijdig) van de koop af te zien."

In dit kader is een regelmatig voorkomende casus dat een werknemer door de bevoegde uitkeringsinstantie niet geschikt wordt geacht de gestelde arbeid te verrichten. ${ }^{\mathbf{2 3 8}}$ Dit bestuursorgaan keurt de werknemer af en kent hem een uitkering toe. De werkgever geeft gehoor aan het overheidsbesluit door de werknemer geen arbeid meer te laten verrichten en de loonbetaling te stoppen. De werknemer is het echter niet eens met het besluit van de uitkeringsinstantie. Hij is van mening is dat hij wel arbeidsgeschikt is. Ook is hij werkwillig. In de rechterlijke procedure blijkt achteraf dat de werknemer inderdaad ten onrechte ongeschikt is bevonden voor zijn werk. Volgens de Centrale Raad van Beroep kan de door de werknemer geleden inkomensschade niet worden toegerekend aan het vernietigde besluit, omdat de schade vooral voortvloeit uit de omstandigheid dat de werkgever niet het volledige loon heeft doorbetaald:

\footnotetext{
"Voorts wijst de Raad erop dat - naar hij, onder meer in zijn hiervoor genoemde uitspraak van 7 april 1999, vaker heeft overwogen - in een geval als dit de gevorderde vermogensschade vooral voortvloeit uit de omstandigheid dat de werkgever niet het - volledige - loon heeft doorbetaald."239
}

In de omstandigheid dat de werkgever zich bij zijn besluit om het loon niet door te betalen heeft verlaten op het overheidsbesluit ziet de Raad onvoldoende grond voor het oordeel dat de inkomensschade dient te worden toegerekend aan het onrechtmatige besluit. De Raad acht hierbij van doorslaggevend belang dat het vernietigde besluit naar zijn aard en strekking slechts ziet op de aanspraak op uitkeringen. In verband hiermee ziet de Raad niet in waarom aan dat besluit relevante betekenis toekomt voor de financiële gevolgen van door appellant en zijn werkgever in het kader van hun arbeidsrechtelijke relatie genomen beslissingen:

\footnotetext{
"In die arbeidsrechtelijke relatie komen aan appellante en haar werkgever eigen verantwoordelijkheden toe met betrekking tot de voor hen bestaande rechten en verplichtingen." $\mathbf{2 4 0}$
}

In één van de genoemde uitspraken verwijst de Centrale Raad ter ondersteuning van zijn oordeel naar het arrest van de Hoge Raad in de parallelle 
loonvorderingszaak. ${ }^{\mathbf{2 4 1}}$ In dit arrest laat de Hoge Raad het risico van het onjuiste arbeidsongeschiktheidsoordeel van de uitkeringsinstantie voor rekening van de werkgever komen. Dit oordeel vormt volgens de Centrale Raad ondersteuning voor zijn zienswijze dat de gestelde schade niet zozeer moet worden toegerekend aan het onjuiste besluit, maar aan de beslissing van de werkgever om de werknemer niet tot het werk toe te laten en het loon niet langer te betalen. Hiermee ben ik het niet eens. In de civiele zaak ging het er ingevolge artikel 7:628 BW om of de werknemer de overeengekomen arbeid niet heeft verricht door een oorzaak die in redelijkheid voor rekening van de werkgever behoort te komen. In die procedure was het bestuursorgaan, dat het onrechtmatige besluit had genomen, geen partij. Het oordeel van de Hoge Raad heeft naar mijn mening alleen betekenis in de verhouding werkgever/werknemer en houdt slechts in dat de schadeoorzaak van het onjuiste besluit niet voor rekening van de werknemer, maar voor rekening van de werkgever, dient te komen. Dit is iets anders dan de vraag of de schade kan worden toegerekend in de zin van 6:98 BW en het zegt naar mijn mening niets over aansprakelijkheid van de uitkeringinstantie voor het onrechtmatige besluit. Ook Kortmann wijst erop dat deze redenering van de Centrale Raad van Beroep niet sluitend is, omdat het Burgerlijk Wetboek hoofdelijke aansprakelijkheid kent. ${ }^{\mathbf{2 4 2}}$ Het is dus goed mogelijk dat zowel de werkgever als de uitkeringsinstantie jegens de werknemer aansprakelijk zijn voor de schade. Bovendien neemt de Centrale Raad ook geen aansprakelijkheid van de uitkeringsinstantie aan voor onjuiste arbeids(on)geschiktheidsoordelen als de werknemer zijn schade niet op werkgever kan verhalen. ${ }^{\mathbf{2 4 3}}$ Van Maanen noemt de motivering van de Centrale Raad van Beroep in deze uitspraak een 'gekunstelde redenering', die haaks staat op de civielrechtelijke dogmatiek inzake causaal verband. ${ }^{\mathbf{2 4 4}}$ Het is volgens hem vanzelfsprekend dat de afkeuring en de daarop volgende uitkering tot gevolg hebben dat de werkgever stopt met loondoorbetaling. Van Maanen is van mening dat er dan geen enkele ruimte meer is voor de werkgever om zich anders op te stellen, omdat hij niet gehouden is om aan de werknemer tegen de formeel vastgelegde opvatting van deskundigen in loon door te betalen en de werknemer eventueel zelfs aan het werk te zetten. Dit laatste zou naar zijn mening tot forse schadeclaims kunnen leiden als de gezondheidstoestand van de werknemer als gevolg daarvan verergert. Van Maanen ziet de risicoaansprakelijkheid voor vernietigde besluiten als reden voor dergelijke gekunstelde redeneringen met betrekking tot het causaal verband. Dit geldt volgens hem met name in de situaties waarin het bestuursorgaan niet onzorgvuldig jegens de benadeelde heeft gehandeld. Het gevolg hiervan is dat de bestuursrechter zich soms in bochten moet wringen om in gevallen waarin hij schadevergoeding niet redelijk acht de vordering toch af te wijzen ondanks de vaststaande onrechtmatigheid. Van Maanen meent dat de gekunstelde en over gesimplificeerde 'causaal verband ontbreekt' redeneringen hieraan te wijten zijn. Als oplossing stelt hij voor om af te stappen van het automatisme dat de vernietiging van een besluit tevens de onrechtmatigheid daarvan betekent en in plaats daarvan uit te gaan van een weerlegbaar vermoeden van onrechtmatigheid. $\mathbf{2 4 5}$

Smits kan zich als privatist niet aan de indruk onttrekken dat achter het afwezig achten van causaal verband in de uitspraken over het onjuiste arbeidsongeschiktheidsoordeel een hele gedachtewereld schuil gaat die in de uitspraken niet expliciet wordt gemaakt en dat de motivering van de Centrale 
Raad niet uitdrukt wat dit college redengevend acht voor zijn oordeel. Dit vindt hij jammer. Vanuit puur privaatrechtelijk oogpunt is er volgens hem namelijk weinig op tegen om in dergelijke zaken wel causaal verband aan te nemen. Hij wijst erop dat zelfs voldaan is aan de eis van voorzienbaarheid, omdat voorzienbaar was dat intrekking van de uitkering zou leiden tot de schade. Het verzoek tot schadevergoeding dan toch afwijzen is naar zijn mening wel mogelijk, maar dan toch niet met een beroep op afwezigheid van causaal verband: dat rekt de spankracht van die eis teveel op. $\mathbf{2 4 6}$

In tegenstelling tot deze jurisprudentie heeft de Centrale Raad bij onjuiste arbeidsongeschiktheidsoordelen wel causaal verband aangenomen in zaken waarin omgekeerd de werknemer ten onrechte arbeidsgeschikt werd verklaard, terwijl hij zelf aangaf niet tot werken in staat te zijn. De schadeclaim wordt in die uitspraken niet afgewezen met het argument dat geen causaal verband bestaat omdat de schade vooral wordt veroorzaakt door de beslissing van de werkgever om de werknemer te laten werken en niet door het onjuiste besluit.

Dit is bijvoorbeeld het geval in een zaak waarin een kantoorleider van een bank zijn werk had moeten staken vanwege een blaascarcinoom. ${ }^{\mathbf{2 4 7}} \mathrm{Na}$ een intensieve behandeling van chemotherapie en bestralingen ging hij weer gedeeltelijk aan het werk. Op een gegeven moment moest hij van de uitkeringsinstantie weer voltijds aan de slag, terwijl hij aangaf dit niet aan te kunnen wegens vermoeidheidsklachten. Hij probeert zijn baan weer volledig te hervatten, maar valt uit. De uitkeringsinstantie weigert echter zijn uitkering te verhogen. Ook zijn werkgever geeft hem te kennen dat hij weer voltijds moet gaan werken. De werknemer probeert dit tot tweemaal toe, maar valt beide keren uit wegens spanningsklachten. Een psychiater constateert een ernstige depressie en een angststoornis. Naar het oordeel van de Centrale Raad is aannemelijk dat het psychisch letsel van de werknemer is veroorzaakt door samenlopende oorzaken, te weten het zich niet erkend voelen in de medische grondslag van zijn klachten door de uitkeringsinstantie en later ook door zijn werkgever. De Centrale Raad sluit in deze uitspraak aan bij de hoofdelijke aansprakelijkheid van artikel 6:102 lid 1 BW:

"In een geval waarin dezelfde schade is ontstaan door een samenloop van oorzaken, zijn volgens het civiele recht op grond van artikel 6:102, eerste lid van het BW de voor dezelfde schade aansprakelijke personen hoofdelijk voor het geheel aansprakelijk. De onderlinge bijdrage aan de schade kan vervolgens een rol spelen in het kader van de onderlinge bijdrageplicht."

De uitkeringsinstantie voert nog aan dat de psychische schade mede het gevolg is geweest van persoonlijke verliezen dan wel omstandigheden van de betrokkene en dat daarom de schade niet aan hem kan worden toegerekend. De Raad gaat daar niet in mee:

"Ten aanzien van het standpunt van appellant (de uitkeringsinstantie, $L D B$ ) dat de schade mede het gevolg is geweest van de persoonlijke verliezen van gedaagde dan wel andere bijzondere omstandigheden [...]overweegt de Raad dat bij een onrechtmatige daad die bestaat in het toebrengen van letsel, de gevolgen van een door de persoonlijke predispositie van het slachtoffer bepaalde reactie op die daad in het algemeen als een gevolg van de onrechtmatige daad aan de dader moeten worden toegerekend. Dit zou 
anders zijn in het geval van bijzondere omstandigheden waarvan de Raad niet is gebleken."

In deze uitspraak speelt derhalve ook een rol de vraag welke invloed de persoonlijke predispositie van de benadeelde heeft op het toerekeningsoordeel. Volgens de Hoge Raad zullen bij een onrechtmatige daad die bestaat uit het toebrengen van letsel de gevolgen van een door de persoonlijke predispositie van het slachtoffer bepaalde reactie op die daad in het algemeen als een gevolg van de onrechtmatige daad aan de dader moeten worden toegerekend ook al zijn die gevolgen daardoor ernstiger en langer van duur dan in de normale lijn der verwachtingen ligt. ${ }^{\mathbf{2 4 8}} \mathrm{Bij}$ een onrechtmatige daad die niet bestaat in het toebrengen van letsel lijkt het van de geschonden norm en de concrete omstandigheden van het geval af te hangen of een dergelijke ruime toerekening plaatsvindt. ${ }^{249}$ De Centrale Raad van Beroep lijkt aansluiting te zoeken bij deze rechtspraak. Hij bepaalt dat bij een onrechtmatige daad die bestaat in het toebrengen van letsel, de gevolgen van een door de persoonlijke predispositie van het slachtoffer bepaalde reactie op die daad in het algemeen als een gevolg van de onrechtmatige daad aan de dader moeten worden toegerekend. ${ }^{\mathbf{2 5 0}}$ Het is opvallend dat het in deze zaak ging om een onrechtmatig besluit van de uitkeringsinstantie waarin een werknemer ten onrechte arbeidsgeschikt wordt verklaard en daardoor psychisch letsel opliep. Blijkbaar moet dit volgens de Raad worden gezien als een onrechtmatige daad, die bestaat in het toebrengen van letsel.

Ook in een andere uitspraak, waarin het ging om een werknemer die ten onrechte arbeidsgeschikt werd geacht en daardoor psychisch letsel opliep en inkomensschade leed, heeft de Centrale Raad toerekening daarvan aan de uitkeringsinstantie aangenomen. ${ }^{\mathbf{2 5 1}}$ De werknemer heeft meerdere keren geprobeerd weer (voltijds) aan het werk te gaan, maar valt steeds uit. In beroep tegen de arbeidsgeschiktheidbesluiten heeft de rechtbank zich laten adviseren door onafhankelijke deskundige artsen. De artsen menen dat betrokkene onterecht arbeidsgeschikt is verklaard. In één van de deskundigenrapporten wordt overwogen dat het erop lijkt dat de beslissing om hem arbeidsgeschikt te verklaren niet alleen onterecht was, maar een sterke verslechtering heeft gegeven van het functioneren van betrokkene. Volgens dit rapport is het nog maar de vraag of deze verslechtering te herstellen is. Op grond van de deskundigenverklaringen heeft de uitkeringsinstantie betrokkene alsnog volledig arbeidsongeschikt verklaard.

Hij vraagt daarom vergoeding van de geleden materiële en immateriële schade. Voor zijn conclusie dat deze schade aan het bestuursorgaan kan worden toegerekend in de zin van artikel 6:98 BW acht de Raad van belang dat, gelet op de persoonlijkheidsstructuur van betrokkene en het feit dat als hij niet aan het werk ging hij geen inkomen meer zou ontvangen, het voor de uitkeringsinstantie redelijkerwijs was te voorzien dat betrokkene weer volledig aan het werk zou gaan, ook al achtte hij zichzelf daartoe niet in staat. Uit verschillende deskundigenrapporten blijkt volgens de Raad dat het psychisch letsel het gevolg is van de onrechtmatige besluiten. Uit deze rapporten leidt de Raad af dat de betreffende besluiten niet verantwoord waren. Dit betekent naar de mening van de Raad dat het bestuursorgaan een voorzienbaar risico op hernieuwde uitval op zich heeft genomen. Voor zijn conclusie dat in dit geval is voldaan aan het vereiste van toerekening lijkt de Raad dus in ieder geval van belang te vinden dat 
de schade voorzienbaar was. Ook overweegt de Raad:

\begin{abstract}
"Op grond van de in de voorgaande overwegingen genoemde omstandigheden komt de Raad, met name gelet op de aard en strekking van het vernietigde besluit en op de aard van de schade, tot de conclusie dat er een zodanig verband is tussen de gevorderde schadeposten en het onrechtmatige besluit, dat deze schade aan de gedaagde moet worden toegerekend."
\end{abstract}

Ook de aard en strekking van het besluit en de aard van de schade spelen dus een rol in het toerekeningsoordeel van de Raad. Met 'aard van de schade' zou het erom kunnen gaan dat sprake is van (psychische) letselschade, hoewel ook inkomensschade wordt gevorderd. Met betrekking tot de aard en de strekking van het besluit merkt de Raad nog op dat deze factoren weliswaar van belang zijn bij beantwoording van de toerekeningsvraag, maar er niet steeds toe leiden dat in dergelijke zaken geen sprake is van causaal verband. Dit hangt volgens de Raad af van de omstandigheden van het concrete geval.

Deze overweging sluit aan bij de multi-factor benadering van het vereiste van toerekening in het civiele recht.

Zoals gezegd wijst de Centrale Raad van Beroep de schadevordering in deze twee zaken in ieder geval niet af met het argument dat de schade niet wordt veroorzaakt door het vernietigde besluit, maar door de beslissing van de werkgever om de werknemer te laten werken. Ook de aard en strekking van het vernietigde besluit leiden niet tot afwijzing van de schadevordering.

Het feit dat het (mede) gaat om (het toebrengen van) letselschade lijkt in beide uitspraken een rol te spelen bij de conclusie dat de schade kan worden toegerekend. In de tweede zaak wordt daarbij ook gewicht toegekend aan de voorzienbaarheid van de schade en de aard en strekking van het vernietigde besluit. Uit de uitspraak blijkt niet welke betekenis aan deze laatste factor toekomt. Een nadere toelichting hieromtrent zou naar mijn mening gewenst zijn. Dit geldt te meer nu we hiervoor hebben gezien dat de aard en strekking van dergelijke besluiten in de omgekeerde situatie voor de Centrale Raad juist de doorslaggevende reden is om de vordering af te wijzen.

Schlössels meent in zijn noot bij deze uitspraak ook dat het gaat om een ernstiger zorgvuldigheidsgebrek aan de zijde van de uitkeringsinstantie dan in de zaken waarin een werknemer ten onrechte arbeidsongeschikt wordt geacht.

\title{
Ad b
}

Betrokkene zit in de bijstand en krijgt op grond van een re-integratietraject een arbeidsverplichting opgelegd. ${ }^{\mathbf{2 5}}$ Zij weigert een aangeboden baan, waarop zij voor een maand voor $100 \%$ wordt gekort op haar uitkering. Later krijgt zij opnieuw een baan aangeboden bij IJmond Groen voor het verrichten van werkzaamheden als kantinemedewerkster voor de duur van 32 uur per week. Deze neemt zij aan, maar meldt zich de eerste dag ziek. De volgende dag wordt zij voor ongeveer twee weken opgenomen in verband met psychische klachten. Later wordt het bezwaar tegen het besluit waarop betrokkene voor een maand voor 100\% wordt gekort op haar uitkering alsnog gegrond verklaard. Hierbij verwijst het bestuursorgaan naar een rapportage arbeidsonderzoek en geeft aan dat daaruit blijkt dat de arbeidsmogelijkheden van betrokkene beperkt lijken te zijn als gevolg van vermoeidheidsproblemen en psychosociale problemen. De 
rechtbank vernietigt ook de beslissing op bezwaar waarbij het bezwaar tegen het opleggen van de arbeidsverplichting ongegrond is verklaard. Hij wijst echter het verzoek tot vergoeding van immateriële schade af, omdat appellante onvoldoende heeft aangetoond dat de door haar geleden schade is veroorzaakt door het besluit om haar de arbeidsverplichting op te leggen.

In hoger beroep voert appellante daartegen aan dat zij niet in staat was te werken en dat al had aangegeven voordat zij met haar werk was begonnen. Door het korten van haar uitkering met $100 \%$ voor een maand voelde zij zich gedwongen aan het werk te gaan. Naar de mening van appellante is het causale verband tussen de ontstane psychische klachten in verband waarmee zij is opgenomen en de opgelegde maatregel evident. De Raad begint zijn overwegingen met betrekking tot het causaal verband door aan te sluiten bij artikel 6:98 BW:
"Volgens vaste jurisprudentie van de Raad is voor vergoeding van schade vereist dat de gestelde schade verband houdt met het onrechtmatige besluit en voorts dat alleen die schadeposten voor vergoeding in aanmerking komen die in een zodanig verband staan met dat besluit dat zij het bestuursorgaan, mede gezien de aard van de aansprakelijkheid (en) van de schade, als een gevolg van dat besluit kunnen worden toegerekend. Bij de beoordeling of toegerekend moet worden acht de Raad ook de aard en strekking van het onrechtmatige besluit een relevante factor."

De Centrale Raad komt tot het oordeel dat het causaal verband ontbreekt. De Raad stelt vast dat appellante ter toelichting op haar verzoek om schadevergoeding heeft aangegeven dat de causale relatie tussen het gestelde geestelijk letsel en de niet gehandhaafde maatregel kan worden afgeleid uit de chronologische volgorde van het opleggen van deze maatregel, het verrichten van de werkzaamheden en haar ziekenhuisopname. Op basis van deze toelichting is het vereiste causale verband volgens de Raad onvoldoende aangetoond:

\begin{abstract}
"Een nadere onderbouwing zou daarvoor noodzakelijk zijn geweest, te meer nu namens appellante eveneens is gesteld dat reeds sprake was van psychische klachten voorafgaand aan het besluit [...], waarbij is aangegeven dat op haar de arbeidsverplichting van toepassing is. Gebleken is voorts dat aan appellante al op 13 juli 2006 en op 14 juli 2006 antidepressiva zijn voorgeschreven, hetgeen er op wijst dat haar psychische klachten reeds vóór de indiensttreding bij IJmond Groen aanwezig en tot uiting gekomen waren."
\end{abstract}

Het gaat er dus om dat volgens de Raad het causale verband niet voldoende is aangetoond. Hiermee geeft de Raad eigenlijk te kennen er niet van overtuigt te zijn dat de schade feitelijk is veroorzaakt door het onrechtmatige besluit. Daarbij speelt volgens hem een rol dat de psychische klachten al aanwezig en tot uiting gekomen waren voor de indiensttreding. De laatste geciteerde overweging gaat mijns inziens derhalve niet zozeer over het vereiste van toerekening, maar ziet op het ontbreken van een condicio sine qua non verband. ${ }^{\mathbf{2 5 3}}$

Vertragingsschade bij de bouw van vakantiebungalows wordt volgens de Afdeling niet veroorzaakt door het vernietigde besluit, maar heeft de benadeelde aan zichzelf te wijten. ${ }^{\mathbf{2 5 4}}$ Een eigenaar van een bungalowpark wil dit park graag 
uitbreiden. Hij kan 31 huisjes laten bijbouwen, maar wil meer. Dit zou kunnen als de bestemming 'verblijfsrecreatie' zou worden gegeven aan een 15 meter brede strook. In eerste instantie keuren Gedeputeerde Staten het betreffende bestemmingsplan geheel goed, maar deze goedkeuring wordt op formele gronden vernietigd. Vervolgens beslissen zij opnieuw. Deze beslissing wordt door de Afdeling vernietigd voor zover goedkeuring was onthouden aan de bestemming 'verblijfsrecreatie' van de 15 meter brede strook. Uiteindelijk krijgt een strook van vijf meter breed wel deze bestemming; aan de overige strook van 10 meter onthouden Gedeputeerde Staten hun goedkeuring. Hierdoor kan de eigenaar van het bungalowpark zijn park met 33 huisjes uitbreiden. Hij stelt door de gang van zaken (vertragings)schade te lijden bij de voorgenomen uitbreiding van zijn bungalowpark. De Afdeling wijst zijn verzoek om vergoeding van de vertragingsschade af. Zij legt hieraan ten grondslag dat de eigenaar van het perceel ook na de vernietiging van het besluit tot onthouding van de goedkeuring aan de bestemming 'verblijfsrecreatie' voor de 15 meter brede strook de mogelijkheid had om zijn bungalowpark uit te breiden met 31 huisjes, maar dit niet heeft geëffectueerd door het aanvragen van een bouwvergunning en het opstellen van een verkavelingsplan, waarin het ook mogelijk zou zijn om ruimte te laten voor extra huisjes voor het geval dat door het definitieve besluit nog extra bouwmogelijkheden zouden ontstaan. Ook neemt de Afdeling mee dat niet is gebleken van een ondernemingsplan waarin de voorgenomen uitbreiding van het bungalowpark is opgenomen. De conclusie:

\footnotetext{
"Nu appellant geen pogingen heeft ondernomen om de bouwmogelijkheden die hij na het besluit van 10 april 1995 redelijkerwijs had te realiseren, kan de schade die appellant stelt te hebben geleden door het niet eerder verwezenlijken van zijn bouwplannen naar het oordeel van de Afdeling niet worden toegerekend aan dat besluit."
}

\section{Combinatie $\mathrm{a} \& \mathrm{~b}$}

In het volgende voorbeeld gaat het om een appellante, die volledig rolstoelgebonden is. ${ }^{\mathbf{2 5 5}} \mathrm{Zij}$ is als telefoniste/informatrice in dienst getreden bij haar werkgever en naderhand bevorderd tot manager. Met ingang van haar dienstverband heeft zij van de uitkeringsinstantie een volledige taxivergoeding voor het woon/werkverkeer toegekend gekregen. Na een aantal jaren trekt het bestuursorgaan de taxivergoeding in. Appellante heeft geprobeerd met het openbaar vervoer naar haar werk te gaan, maar dit bleek niet haalbaar. Daarop heeft de werkgever vrijwillig en uitdrukkelijk onder voorbehoud van tijdelijkheid besloten de kosten van het woon/werkverkeer per taxi voorlopig voor zijn rekening te nemen. Op een gegeven moment geeft de werkgever aan dat hij wil stoppen met de vrijwillige taxivergoeding. Appellante reageert daarop door aan te geven dat zij dan haar werk niet meer zou kunnen bereiken. Voor de werkgever is deze situatie aanleiding geweest om het voornemen kenbaar te maken de arbeidsovereenkomst te ontbinden. Nog voor de ontbinding kent de uitkeringsinstantie in een nieuw besluit aan appellante echter alsnog de taxivergoeding toe en de werkgever ziet daarom af van het voorgenomen ontslag. Ook komt vast te staan dat de taxivergoeding nooit had mogen worden ingetrokken en de uitkeringsinstantie erkent de onrechtmatigheid van dit besluit. Appellante heeft vervolgens getracht schadevergoeding te krijgen. De 
uitkeringsinstantie heeft een deel van de gevraagde schade toegekend, maar weigert een vergoeding voor inkomensschade ten gevolge van een gebroken carrièreopbouw en voor immateriële schade. Met betrekking tot de inkomensschade voert appellante in de procedure bij de Centrale Raad van Beroep aan dat indien aanstonds de juiste voorziening woon/werkverkeer zou zijn toegekend geen carrièrebreuk was opgetreden. De Raad is van mening dat de gestelde schade niet in zodanig verband staat met het onrechtmatige besluit dat deze het bestuursorgaan, mede gezien de aard van de aansprakelijkheid en van de schade als een gevolg van dat besluit kan worden toegerekend. Bij de beoordeling of toegerekend moet worden acht de Raad de aard en de strekking van het onrechtmatige besluit een relevante factor. De Raad is van mening dat causaal verband ontbreekt:

\begin{abstract}
"Dienaangaande is de Raad, op grond van de in dit geding ter beschikking staande gegevens van oordeel dat de door appellante met een carrièrebreuk in verband gebrachte gestelde inkomensschade vooral voortvloeit uit de omstandigheid dat de werkgever eind 1993/begin 1994 voornemens is geweest om de met appellante bestaande dienstbetrekking per 1 april 1994 door middel van ontbinding te beëindigen. Dit voornemen vond zijn oorzaak in een samenstel van factoren, namelijk enerzijds in de beslissing van die werkgever om de door hem vrijwillig, uitdrukkelijk ten titel van tijdelijkheid uitbetaalde taxivergoeding niet langer te continueren en anderzijds in het feit dat appellante jegens hem te kennen had gegeven dat zij in dat geval niet langer in staat was om haar werk te bereiken."
\end{abstract}

Ad c

Een andere omstandigheid is aan de orde in een zaak, waarin de uitkeringsinstantie in eerste instantie besloot geen ziekengeld toe te kennen, omdat de betrokkene niet arbeidsongeschikt zou zijn. ${ }^{\mathbf{2 5 6}}$ De rechtbank vernietigt dit besluit echter. Hierdoor heeft de benadeelde over de periode van het onrechtmatige besluit alsnog recht op ziekengeld. Ingevolge zijn CAO zou dit bedrag door zijn voormalige werkgever worden aangevuld tot $100 \%$ van het loon. Zijn voormalige werkgever is echter voor de uitspraak van de rechtbank failliet gegaan. Benadeelde vordert van de uitkeringsinstantie vergoeding van het misgelopen loon. Hij stelt zich hierbij op het standpunt dat, indien in eerste instantie een juist besluit was genomen, zijn werkgever nog niet failliet was geweest en hij de aanvulling op het loon zonder meer zou hebben ontvangen. Deze stelling van appellant is erop gericht het condicio sine qua non verband aan te tonen: zonder het onrechtmatige besluit zou de schade niet zijn geleden. De Raad reageert daarop echter alsof het de toerekeningsvraag betreft:

\footnotetext{
"Aldus vindt deze schade niet zozeer zijn oorsprong in de onjuiste beslissing, maar in het feit dat de werkgever geen verhaal biedt voor zijn achteraf gebleken verplichtingen. Ook de Raad is van oordeel dat dit door appellant geleden nadeel niet in zodanig verband staat met het door de rechtbank vernietigde besluit dat dit, mede gezien de aard van de aansprakelijkheid en de aard van vorenomschreven schade als een gevolg van dat besluit aan gedaagde kan worden toegerekend."
} 
In de laatste uitspraak gaat het om een coffeeshop. De uitspraak zelf geeft over de feiten niet veel bloot, maar volgens de annotator blijkt uit de stukken dat appellanten zich met succes hadden beklaagt over de vergunningverlening ten behoeve van een coffeeshop in hun omgeving. Daarnaast verzochten appellanten om bestuursdwang tot te passen. De handhaving werd onrechtmatig geweigerd. Op grond van deze twee onrechtmatige besluiten vorderden appellanten schadevergoeding in verband met, zover hier van belang, vermindering van hun woongenot vanwege permanente overlast. De gemeente nam wel aan dat het woon- en leefklimaat in de omgeving van de coffeeshop werd aangetast, maar pas nadat een andere coffeeshop in de gemeente door brand werd gesloten. Hierdoor kreeg de coffeeshop in de buurt van appellanten meer klandizie. Appellanten krijgen hun schade niet vergoed. De vermindering van het woongenot is volgens de Afdeling niet veroorzaakt door de onrechtmatige besluiten:

"[...] dat, voor zover vanaf medio januari 1998 als gevolg van de sluiting van een andere coffeeshop en de daarmee gepaard gaande toename van de klandizie van coffeeshop $X$ wel sprake is geweest van een relevante vermindering van het woongenot van appellanten, deze niet is veroorzaakt door het door de burgemeester gehandhaafde besluit tot verlening van de exploitatievergunning, nu dat besluit door de rechtbank bij uitspraak van 29 juli 1997 is herroepen. Zij is evenzeer terecht tot de slotsom gekomen dat de schade evenmin is veroorzaakt door de weigering van burgemeester en wethouders om bestuursdwang toe te passen en dat ook het niet tijdig nemen van een nieuwe beslissing op het bezwaar daaromtrent in dit geval niet leidt tot een verplichting tot schadevergoeding voor burgemeester en wethouders."257

De exploitatievergunning voor de coffeeshop was al herroepen voordat de schade werd geleden en kon om die reden niet de oorzaak van de schade zijn. Met betrekking tot de weigering tot handhaving heeft de Afdeling niet expliciet gemotiveerd waarom de schade hierdoor naar haar mening niet is veroorzaakt. Blijkens de noot is de redenering dat dit besluit dateerde van voor de brand en de coffeeshop voor de brand van de andere coffeeshop het woon- en leefklimaat niet aantastte; een weigering om bestuurdwang toe te passen kan dan volgens de annotator niet de oorzaak van de vermindering van het woongenot zijn. Het lijkt erop dat de Afdeling niet het niet handhaven, maar de brand in de andere coffeeshop als oorzaak van de schade ziet, hoewel zij dit niet expliciet overweegt. Het condicio sine qua non verband lijkt mij evenwel aanwezig: als de gemeente rechtmatig had gehandeld en bestuursdwang had toegepast, was de coffeeshop er niet meer geweest en was er, brand of geen brand, geen overlast geweest.

\section{Literatuur}

Van Maanen en Schlössels wijzen er ook op dat bestuursrechters met regelmaat causaal verband ontkennen tussen onrechtmatige besluiten en schade op grond van het feit dat de schade niet het gevolg is van onrechtmatig handelen van het bestuur, maar van handelen of nalaten van gelaedeerde zelf of andere oorzaken kent. Tevens wordt volgens hen de strenge eis van 'direct' of 'voorzienbaar' gevolg gesteld. ${ }^{\mathbf{2 5} 8}$

Schlössels stelt in dit kader de vraag in hoeverre een onrechtmatig besluit kan 
gelden als schadeoorzaak, omdat een besluit in beginsel slechts leidt tot een wijziging of een (nadere) vaststelling van de rechtspositie van burgers en daardoor hun gedrag beïnvloedt. ${ }^{259}$ De schade is volgens Schlössels dan ook in eerste instantie het gevolg van een doen of nalaten van burgers in reactie op het onrechtmatige besluit: er is dus steeds sprake van een complexe, samengestelde causaliteitsketen. Hij meent dat het gaat om beantwoording van de vraag of door het publiekrechtelijk rechtshandelen de kans op het ontstaan van de schade is vergroot. $^{\mathbf{2 6 0}}$ Naar civielrechtelijke maatstaven beschouwd dient de causaliteit naar zijn mening op grond van artikel 6:98 BW te worden vastgesteld aan de hand van een op basis van redelijkheidsmaatstaven gecorrigeerde voorzienbaarheidsleer. Deze leer omvat volgens hem mede een (geobjectiveerde) waarschijnlijkheidscomponent. Hierbij komt de vraag aan de orde wat van de gemiddelde burger in reactie op publieke besluitvorming, gegeven de omstandigheden, mag worden verwacht. ${ }^{\mathbf{2 6 1}} \mathrm{Nu}$ schade door een vernietigd besluit zoals gezegd het gevolg is van een keten van oorzaken meent Schlössels dat het aan de schadevergoedingsrechter is om te komen tot een toerekening van de schade naar redelijkheid aan één of aan verschillende oorzaken. In het laatste geval kan er volgens hem sprake zijn van een draaglastverdeling, waarbij de toepassing van concepten als 'eigen schuld' en 'risicoaanvaarding' een rol speelt. Naar de mening van Schlössels worstelt de bestuursrechtspraak met het probleem van de samengestelde schadeoorzaken. Het resultaat hiervan is zijns inziens vaak weinig genuanceerd (in die zin dat de bestuursrechter het onrechtmatige besluit meestal niet als schadeoorzaak aanwijst, zo begrijp ik). ${ }^{\mathbf{6 2}}$ Bestuursrechters tonen volgens hem vaak niet veel iniatieven om complexe relaties tussen onrechtmatige besluitvorming en handelen van burgers in reactie daarop te ontrafelen. Het uitgangspunt dat een onrechtmatig besluit het gedrag van burgers steeds gegeven de specifieke omstandigheden van het geval beïnvloedt blijft daarom bij de bepaling van het causaal verband vaak onderbelicht. $^{\mathbf{2 6 3}}$

Naar de opvatting van Schlössels zorgt dit ervoor dat het gedrag van burgers op basis van simpele 'causa proxima' benaderingen als enige oorzaak van de schade wordt aangewezen, terwijl deze naar maatstaven van redelijkheid minimaal mede geacht moet worden te zijn veroorzaakt door het onrechtmatige besluit. ${ }^{\mathbf{2 6 4}}$ Hij noemt dit het wegschaven van overheidsaansprakelijkheid. ${ }^{\mathbf{2 6 5}}$ Reden hiervoor kan zijn dat de bestuursrechter een te vergaande overheidsaansprakelijkheid wil voorkomen. ${ }^{\mathbf{2 6 6}}$

Volgens Tak wordt de schade door de bestuursrechters zeer vaak op dubieuze gronden aangemerkt als een gevolg van een andere gebeurtenis dan het onrechtmatige besluit. ${ }^{\mathbf{2 6} 7}$

Jurgens is van mening dat bij gebrekkige handhaving het niet optreden van de overheid 'slechts' een secundaire factor is in de causaliteitsketen. De overtreder is primair aansprakelijk. Deze situatie zou daarom volgens haar niet op een lijn mogen worden gezet met die waarin meerdere daders zelfstandige onrechtmatige daden plegen. Op grond van de aard van de aansprakelijkheid en van de schade (artikel 6:98 BW) of omstandigheden van het geval zou in dergelijke gevallen slechts een beperkte aansprakelijkheid van de overheid gerechtvaardigd zijn. ${ }^{\mathbf{6 8 8}}$

Beoordeling en conclusie 
De bestuursrechter wijst dus regelmatig schadevorderingen af, omdat de schade volgens hem wordt veroorzaakt door andere omstandigheden dan het onrechtmatige besluit. De Centrale Raad van Beroep koppelt deze motivering aan het toerekeningsvereiste van artikel 6:98 BW: de schade staat niet in een zodanig verband tot het onrechtmatige besluit dat zij aan het bestuursorgaan dat dat besluit heeft genomen, mede gezien de aard van de aansprakelijkheid en van de schade, als een gevolg van dat besluit kan worden toegerekend. In de uitspraken van de Afdeling bestuursrechtspraak van de Raad van State wordt deze koppeling niet gemaakt en blijft in het midden of de conclusie dat de schade is veroorzaakt door andere omstandigheden dan het onrechtmatige besluit volgens de Afdeling een antwoord is op de feitelijke vraag of de schade al dan niet door het onrechtmatige besluit is veroorzaakt of op de rechtsvraag op grond van welke objectieve criteria de schade wel of niet dient te worden toegerekend. ${ }^{\mathbf{2 6 9}}$ In de betreffende bestuursrechtelijke uitspraken is het condicio sine qua non verband tussen de schade en het vernietigde besluit wel steeds aanwezig. ${ }^{\mathbf{2 7 0}}$ Naar mijn mening wijkt deze rechtspraak af van de toepassing van het causaliteitsvereiste van de civiele rechter bij feitelijke handelingen.

Als het condicio sine qua non verband vaststaat, is het feit dat dezelfde schade mede wordt veroorzaakt door andere omstandigheden dan de betreffende onrechtmatige feitelijke handeling voor de Hoge Raad namelijk op zichzelf geen reden om de schadevordering op die grond (geheel) af te wijzen, ook niet als het gaat om overheidsaansprakelijkheid. ${ }^{\mathbf{2 7 1}} \mathrm{Bij}$ meerdere aansprakelijke personen voor dezelfde schade bestaat op grond van artikel 6:102 BW daarvoor hoofdelijke aansprakelijkheid. Als de schade een gevolg is van een omstandigheid die aan de benadeelde kan worden toegerekend, dan wordt de vergoedingsplicht van de aansprakelijke persoon ingevolge artikel 6:101 BW verminderd door de schade over hem en de benadeelde te verdelen in evenredigheid met de mate waarin de aan ieder toe te rekenen omstandigheden tot de schade hebben bijdragen, tenzij uit de billijkheid anders voortvloeit. Bij meerdere schadeoorzaken lijkt de Hoge Raad in recente jurisprudentie bovendien in sommige gevallen de mogelijkheid van proportionele aansprakelijkheid te aanvaarden. ${ }^{\mathbf{2 7}}$ Dit houdt in dat een bepaald percentage van de schade door de normschender wordt vergoed naar rato van waarschijnlijkheid dat hij de schade heeft veroorzaakt.

Als in de civiele rechtspraak eenmaal een condicio sine qua non verband is vastgesteld, komt vervolgens de rechtsvraag aan de orde of de schade op grond van artikel 6:98 BW op basis van objectieve factoren, in onderlinge verhouding bezien, kan worden toegerekend. Het feit dat er meerdere schadeoorzaken en/of schadeveroorzakers voor dezelfde schade bestaan, leidt er dan niet toe dat de schadevordering alleen om die reden niet aan de betreffende onrechtmatige daad kan worden toegerekend en daarom geheel wordt afgewezen. In de besproken bestuursrechtelijke rechtspraak is dit wel het geval.

Één van Brunners deelregels van toerekening luidt dat naarmate het schadelijke gevolg minder ver verwijderd is van de gebeurtenis waarop de aansprakelijkheid berust, toerekening eerder gerechtvaardigd is. Het is mogelijk dat de bestuursrechter met zijn overweging dat geen causaal verband bestaat, omdat de schade is veroorzaakt door andere omstandigheden dan het onrechtmatige besluit, wil aansluiten bij deze deelregel. ${ }^{273}$ Dit kan worden afgeleid uit de bewoordingen in sommige uitspraken dat de schade geen 'voorzienbaar en onontkoombaar'274 of 'rechtstreeks'275 gevolg is van het onrechtmatige besluit. 
Mocht de bestuursrechter inderdaad van mening zijn dat de gevorderde schade in een te ver verwijderd verband staat tot het onrechtmatige besluit om daaraan te kunnen worden toegerekend, dan zou hij er mijns inziens goed aan doen om dit duidelijker in de motivering van de uitspraak tot uitdrukking te brengen. Dit dekt de lading beter en sluit in ieder geval qua bewoordingen aan bij het civiele schadevergoedingsrecht.

Overigens legt de Hoge Raad, indien het condicio sine qua non verband vaststaat, de bewijslast van de stelling dat de schade in een te ver verwijderd verband staat tot de onrechtmatige daad om daaraan te worden toegerekend op degene die zich daarop beroept, zijnde de verweerder tegen de schadevordering. ${ }^{276}$ Mocht de bestuursrechter in dergelijke gevallen deze bewijsregel overnemen, dan betekent dat dus dat de overheid aannemelijk dient te maken dat de schade niet kan worden toegerekend aan het onrechtmatige besluit, omdat het in een te ver verwijderd verband daarmee staat.

Echter: ook als de besproken uitspraken van de bestuursrechter worden gezien in het licht van de verwijderdheid tussen de schade en het onrechtmatige besluit bestaat naar mijn mening verschil tussen deze bestuursrechtspraak en de toepassing door de civiele rechter van de toerekeningsregel dat schade die in een te ver verwijderd verband staat tot de onrechtmatige daad daaraan niet kan worden toegerekend. Verwijderdheid tussen schade en onrechtmatige daad is in het civiele recht zelden een argument om de schadevordering af te wijzen. ${ }^{277} \mathrm{De}$ voorzienbaarheid van de schade speelt in de civiele jurisprudentie een prominentere rol bij beantwoording van de toerekeningsvraag. In de rechtspraak van de bestuursrechter, waarin geen causaal verband wordt aangenomen omdat de schade zou zijn veroorzaakt door omstandigheden die a) voortvloeien uit de inhoud van het onrechtmatige besluit of daar nauw mee samenhangen, lijkt echter het enkele feit dat er tussen de onrechtmatige daad van de overheid en de schade nog een extra 'daad' staat steeds voldoende reden om de schadevordering af te wijzen.

Dit leidt er naar mijn mening toe dat de bestuursrechter schadevorderingen afwijst, omdat deze volgens hem niet voldoen aan het toerekeningsvereiste, terwijl de schade naar 'civiele' maatstaven in ieder geval niet in een te ver verwijderd verband staat tot de onrechtmatige daad: als bijvoorbeeld een uitkeringsorgaan een werknemer onterecht afkeurt en hij inkomensschade leidt, omdat zijn werkgever hem op grond van het afkeuringsbesluit ontslaat, staat deze schade mijns inziens civielrechtelijk gezien niet in een te ver verwijderd verband met de onrechtmatige daad van de overheid om daaraan te kunnen worden toegerekend. ${ }^{\mathbf{2 7 8}}$ Dit geldt mijns inziens ook voor de causale verwijderdheid tussen een ten onrechte verschuldigde premie inzake werknemersverzekeringswetten en het besluit van een organisatie om op basis van deze kosten dan maar minder werknemers in dienst te nemen ${ }^{\mathbf{2 7 9}}$, de verwijderdheid tussen niet handhaven en schade ontstaan door de niet gehandhaafde illegale activiteit ${ }^{\mathbf{2 8 0}}$ en het onrechtmatig geen vergunning toekennen om bepaalde goederen en/of dieren te importeren en daardoor geleden gederfde winst $^{\mathbf{2 8 1}}$ etc.

De vraag is wat de reden voor dit verschil kan zijn. De bestuursrechter geeft in een aantal uitspraken aan dat bij zijn beslissing de aard en strekking van het vernietigde besluit een rol speelt. Deze toerekeningsfactor zal in paragraaf 6.2.3. aan bod komen. De literatuur noemt het corrigeren van de strenge 'pseudorisicoaansprakelijkheid' voor vernietigde besluiten en beperking van de 
overheidsaansprakelijkheid in het algemeen als mogelijke reden voor de strikte toepassing van het causaliteitsvereiste bij besluitenaansprakelijkheid.

Schlössels wijst er ook op dat bij besluitenaansprakelijkheid steeds sprake is van een samengestelde causaliteitsketen. ${ }^{\mathbf{2 8 2}}$

Dit is in de onderhavige zaken inderdaad het geval. In de betreffende uitspraken over besluitenaansprakelijkheid wordt de schade veroorzaakt doordat de burger handelt op basis van de onjuiste inhoud van het besluit. Deze extra 'schakel' tussen de onrechtmatige daad en de schade is in die zin kenmerkend voor dergelijke besluiten. $\mathrm{Nu}$ is deze omstandigheid voor de bestuursrechter reden om de schadeclaim geheel af te wijzen. Wat mij betreft doet dit onvoldoende recht aan het feit dat de onrechtmatige handelingen van de overheid feitelijk wel degelijk in meer of mindere mate hebben bijgedragen aan het ontstaan van de schade. ${ }^{\mathbf{2 8 3}}$ Toch wil de bestuursrechter deze schade blijkbaar niet juridisch toe rekenen. Een genuanceerdere benadering zou zijn om in dergelijke gevallen een proportionele aansprakelijkheid van de overheid aan te nemen. Hierdoor kan worden bewerkstelligd dat de overheid in ieder geval een gedeelte van de schade dient te vergoeden. Vaststelling van het percentage van aansprakelijkheid zie ik vervolgens als volgt. Verplicht het vernietigde besluit tot bepaalde handelingen of geeft het nauwelijks ruimte om anders te handelen dan is gedaan dan lijkt mij een hoog percentage van aansprakelijkheid gerechtvaardigd. Het percentage kan ook 100\% zijn Het onrechtmatige besluit is in dat geval immers de belangrijkste schadeoorzaak. Dit is mijns inziens aan de orde in de uitspraken over de onjuiste arbeidsongeschiktheidsoordelen. ${ }^{\mathbf{2 8 4}}$ Als een uitkeringsinstantie oordeelt dat een werknemer arbeidsongeschikt is en hij om die reden een uitkering ontvangt, is het naar mijn mening niet reëel om te stellen dat de werkgever ruimte heeft om zijn eigen afweging hieromtrent te maken. Het is vanzelfsprekend dat hij dan de werknemer niet meer laat werken en de loonbetaling stopt. ${ }^{\mathbf{2 8 5}} \mathrm{De}$ uitkeringsinstantie wordt immers geacht deskundig op dit gebied te zijn. Het levert bovendien een onwerkbare situatie op als de werkgever in afwijking van het besluit de werknemer zou verplichten om ondanks zijn afkeuring toch door te werken.

Een lager percentage aansprakelijkheid is gerechtvaardigd als het onrechtmatige besluit geen handelingen verplicht stelt, dan wel logischerwijs tot gevolg heeft, en de burger veel vrijheid laat. In dat geval zijn immers de gemaakte keuzes en handelingen van de burger substantiëlere schadeoorzaken en is de rol van de overheid beperkter. Dit geldt bijvoorbeeld voor de inhoud van een overeenkomst, die is gebaseerd op het onjuiste overheidsbesluit. ${ }^{\mathbf{2 8 6}} \mathrm{Het}$ percentage van de aansprakelijkheid van de overheid zou dus mijns inziens moeten aansluiten bij de mate waarin het onrechtmatige besluit al dan geen keuzevrijheid tot handelen dan wel nalaten laat en zal zich bewegen tussen de twee beschreven uitersten. Het voorgestelde criterium haakt aan bij de voorzienbaarheid van de schade. Hierbij speelt ook een rol de vraag wat van de gemiddelde burger in reactie op publieke besluitvorming, gegeven de omstandigheden, mag worden verwacht. ${ }^{\mathbf{2 8}}$ Een goede motivering van het gekozen percentage is noodzakelijk om de gedachtegang van het bestuursorgaan inzichtelijk te maken en de uitspraak overtuigingskracht te geven.

Bij besluitenaansprakelijkheid voor gebrekkige handhaving of gebrekkig toezicht zou wat mij betreft een laag percentage van overheidsaansprakelijkheid passen. ${ }^{\mathbf{2 8 8}}$ In die gevallen is immers, meer dan bij de hiervoor bedoelde zaken waarin op basis van de inhoud van een onjuist besluit is gehandeld, de 
overtreding de primaire oorzaak van de schade. Het niet optreden van de overheid is 'slechts' een secundaire schadeoorzaak. ${ }^{\mathbf{2 8 9}}$

Proportionele aansprakelijkheid wordt doorgaans gekoppeld aan causaliteitsonzekerheid. ${ }^{\mathbf{2 9 0}}$ Hiervan is in de besproken zaken over besluitenaansprakelijkheid geen sprake. Ook los van onzeker causaal verband is naar mijn mening een proportionele aansprakelijkheid echter goed mogelijk. ${ }^{291}$ Voor bijna alle besproken zaken geldt dat, hoewel wel meerdere oorzaken voor de schade bestaan, hiervoor naast de overheid geen derde partij civielrechtelijk aansprakelijk is. Het oordeel over de proportionele aansprakelijkheid van het bestuursorgaan is dan dus het enige rechterlijke oordeel over de kwestie en levert geen problemen met andere partijen op. Dit ligt anders bij onrechtmatige besluiten met betrekking tot handhaving of toezicht. In die zaken is meestal een aansprakelijke civiele partij betrokken. Het is dan lastig voor de bestuursrechter om proportionele aansprakelijkheid van de overheid aan te nemen, omdat dit in strijd kan komen met een eventueel (later) vonnis van de civiele rechter over deze aansprakelijkheid. In dergelijke gevallen zou de bestuursrechter de schadeclaim kunnen verwijzen naar de civiele rechter. Overigens zal deze situatie niet vaak voorkomen. Een aanzienlijk deel van de claims wegens falend toezicht of gebrekkige handhaving betreft immers feitelijk handelen. Ook zal een (groot) deel van de benadeelden direct voor beide claims bij de burgerlijke rechter aankloppen. Hoewel een reëel aandachtspunt, dient dit obstakel dus ook niet overdreven te worden.

Als beide claims aan de burgerlijke rechter worden voorgelegd, dan heeft hij twee mogelijkheden. Volgens het systeem van het BW zou hij in deze situatie hoofdelijke aansprakelijkheid moeten aannemen. In de regresprocedure tussen de overheid en de aansprakelijke civiele partij komt dan tot uiting dat de overheid naar rato van schuld voor een bepaald percentage aansprakelijk is. In de praktijk zal de benadeelde er waarschijnlijk vaak voor kiezen om de overheid aan te spreken vanwege de diepe zakken. Regres is vervolgens niet altijd realistisch. Het risico bestaat dat de overheid dan relatief vaak voor alle schade opdraait. Dit kan wringen, zeker als de bijdrage van de overheid aan het ontstaan van de schade in werkelijkheid relatief klein is. De burgerlijke rechter zou er in dergelijke zaken daarom ook voor kunnen kiezen om een proportionele aansprakelijkheid en een schadevergoedingsplicht naar rato aan te nemen. Dit voorkomt dat de overheid steeds voor alle schade opdraait.

In de andere twee 'categorieën' van de besproken bestuursrechtelijke jurisprudentie worden de schadevorderingen afgewezen, omdat de schade zou zijn veroorzaakt door b) omstandigheden die bij de benadeelden zelf liggen dan wel c) overige omstandigheden. Ook hier bestaat mijns inziens een onderscheid met de civielrechtelijke jurisprudentie over feitelijke handelingen. Is de afwijzing van de schadevordering gebaseerd op het oordeel dat de schade feitelijk niet is veroorzaakt door het onrechtmatige besluit, dan stoelt de afwijzing van de schadeclaim volgens mij in werkelijkheid op het ontbreken van het condicio sine qua non verband en is het geen toerekeningsoordeel. ${ }^{292}$

Als het condicio sine qua non verband wel vaststaat en het dus gaat om de toerekeningsvraag, wordt in het 'civiele' aansprakelijkheidsrecht de schadevordering niet zonder meer geheel afgewezen omdat naast de onrechtmatige daad ook omstandigheden aan de zijde van de benadeelde of andere omstandigheden hebben bijgedragen aan het ontstaan van de schade. Wel wordt de schade ingevolge artikel 6:101 BW naar rato verdeeld tussen 
degene, die aansprakelijk is uit onrechtmatige daad, en de betreffende benadeelde indien de schade mede een gevolg is van een omstandigheid die aan de benadeelde kan worden toegerekend. Ik zie geen reden waarom dit anders zou moeten zijn in het geval van aansprakelijkheid voor onrechtmatige besluiten. ${ }^{293}$ Het ligt mijns inziens dan ook voor de hand om in de betreffende zaken aan te sluiten bij artikel 6:101 BW. ${ }^{294}$

Jurisprudentie

In de jurisprudentie van de Centrale Raad van Beroep worden regelmatig de aard en strekking van het vernietigde besluit genoemd als factoren, die een rol spelen bij beantwoording van de vraag of de schade al dan niet kan worden toegerekend. De standaardoverweging luidt:

\begin{abstract}
"Volgens vaste jurisprudentie van de Raad is voor vergoeding van schade vereist dat de gestelde schade verband houdt met het onrechtmatige besluit en voorts dat alleen die schadeposten voor vergoeding in aanmerking komen die in een zodanig verband staan met dat besluit dat zij het bestuursorgaan, mede gezien de aard van de aansprakelijkheid (en) van de schade, als een gevolg van dat besluit kunnen worden toegerekend. Bij de beoordeling of toegerekend moet worden acht de Raad ook de aard en strekking van het onrechtmatige besluit een relevante factor."
\end{abstract}

In de meeste uitspraken wordt echter naast de laatste zin van de overweging verder niets opgemerkt over de aard en strekking van het besluit, zodat niet duidelijk wordt welke invloed de aard en strekking van het vernietigde besluit hebben op het toerekeningsoordeel van de Raad in het concrete geval. 295 In de reeds besproken uitspraken over de onjuiste arbeidsongeschiktheidsoordelen gaat de Raad wel nader in op de rol van de aard en strekking van het vernietigde besluit als toerekeningsfactor.

In de situatie waarin de werknemer inkomensschade lijdt, omdat hij door de uitkeringsinstantie ten onrechte arbeidsongeschikt wordt verklaard, bestaat volgens de Centrale Raad geen causaal verband tussen dit oordeel en de schade. De schade wordt volgens de Centrale Raad niet veroorzaakt door het onjuiste besluit, maar vloeit vooral voort uit de omstandigheid dat de werkgever niet het volledige loon heeft doorbetaald. ${ }^{\mathbf{2 9 6}}$ In de omstandigheid dat de werkgever zich hierbij heeft laten leiden door het onjuiste arbeidsongeschiktheidsoordeel van de uitkeringsinstantie ziet de Raad onvoldoende grond gelegen voor het oordeel dat de gevolgen daarvan dienen te worden toegerekend aan het vernietigde besluit. Aard en strekking van het besluit acht de Raad voor dit oordeel steeds van doorslaggevend belang:

"Hierbij acht de raad van doorslaggevende betekenis dat het vernietigde besluit naar zijn aard en strekking slechts ziet op appellantes aanspraak op uitkeringen krachtens de AAW en WAO jegens gedaagde. De Raad vermag dan ook niet in te zien waarom aan dat besluit relevante betekenis toekomt voor de - ( financiële) gevolgen van - door appellante en haar werkgever in het kader van hun arbeidsrechterlijke relatie genomen beslissingen. In die arbeidsrechtelijke relatie komen aan appellante en haar werkgever eigen verantwoordelijkheden toe met betrekking tot de voor hen bestaande rechten 
en verplichtingen. "297

Aard en strekking van het besluit leiden bij onjuiste arbeidsongeschiktheidsoordelen niet per definitie tot de conclusie dat causaal verband ontbreekt. ${ }^{\mathbf{2 9 8}}$ Bij het onjuiste oordeel, dat een werknemer arbeidsgeschikt is en hij hierdoor psychisch letsel opliep, heeft de Centrale Raad wel toerekening van de schade aan de uitkeringsinstantie aangenomen. De werknemer vorderde vergoeding van inkomensschade en immateriële schade. De Raad vindt de aard en strekking van het vernietigde besluit in dergelijke zaken weliswaar een relevante factor bij beantwoording van de toerekeningsvraag, maar niet de enige. Bovendien leiden aard en strekking van het besluit er niet toe dat nooit sprake is van causaal verband. Dit hangt af van de omstandigheden van het geval:

"In deze uitspraak ligt derhalve niet het oordeel van de Raad besloten dat enkel de aard en strekking van een besluit over (de intrekking van) een arbeidsongeschiktheidsuitkering er steeds toe leiden dat geen sprake is van een toereikend causaal verband wanneer schade aan de orde is die verband houdt met een door het uitvoeringsorgaan overgenomen - nadien onjuist gebleken - oordeel van een verzekeringsarts en/of een arbeidsdeskundige over de (mate van) arbeidsongeschiktheid van een werknemer/verzekerde. Of daarvan sprake is, hangt - zoals uit even vermelde uitspraak blijkt - af van de omstandigheden van het concrete geval."299

In deze zaak speelde aard en strekking van het onrechtmatige besluit een belangrijke rol voor het oordeel van de Raad dat wel causaal verband bestond:

\begin{abstract}
"De arbeidsongeschiktheidswetgeving strekt ertoe personen die ten gevolge van ziekte of gebrek geen of minder inkomsten uit arbeid kunnen verwerven, een inkomensvervangende uitkering te verstrekken. Indien een werknemer, zoals appellant, weer volledig geschikt wordt verklaard voor het verrichten van zijn eigen werk, dient deze zijn werk in het kader van zijn dienstbetrekking in beginsel weer volledig te hervatten teneinde van inkomsten uit of in verband met arbeid verzekerd te blijven."
\end{abstract}

Bij de beslissing dat in deze zaak was voldaan aan het vereiste van toerekening speelden, naast de aard en strekking van het besluit, ook de voorzienbaarheid en de aard van de schade een rol.

\title{
Literatuur
}

Het criterium van de Centrale Raad van Beroep dat bij beantwoording van de toerekeningsvraag ook de aard en de strekking van het vernietigde besluit een relevante factor zijn, wordt ook in de literatuur besproken. Auteurs zijn van mening dat de Centrale Raad hier een koppeling maakt met de relativiteitsleer van artikel 6:163 BW. Kortmann wijst erop dat het oordeel van de Centrale Raad in deze zaken een opvatting is over de reikwijdte van een wettelijke norm en dus een relativiteitsoordeel. Hiervan uitgaande schiet de motivering van de uitspraak naar zijn mening tekort, omdat een oordeel dat relativiteit ontbreekt gemotiveerd dient te worden aan de hand van een aantal factoren die de 
beschermingsomvang van een norm bepalen: de wettekst, wetsgeschiedenis, wetssystematiek en de verkeersopvattingen ter zake. ${ }^{\mathbf{3 0 o}}$

Volgens Van Rossum en De Witte-van den Haak blijkt uit de zaken over de vraag of bij onjuiste oordelen over de arbeidsgeschiktheid van een werknemer de uitkeringsinstantie al dan niet aansprakelijk is duidelijk dat de eis van causaal verband in bestuursrechtelijke zaken anders kan uitpakken dan in civielrechtelijke zaken. Zij menen dat de burgerlijke rechter hier vrijwel zeker wel causaal verband zou hebben aangenomen. Zij wijzen erop dat in deze zaken voldaan is aan het condicio sine qua non vereiste, maar dat de Centrale Raad dit niet voldoende acht met verwijzing naar de aard en strekking van het vernietigde besluit. Aard en strekking van het besluit kunnen volgens hen ook niet op iets anders zien dan op de toekenning van uitkeringsaanspraken door het bestuursorgaan aan burgers. Net als Kortmann vinden ook Van Rossum en De Witte-van den Haak dat het meewegen van de aard en strekking van het vernietigde besluit doet denken aan de relativiteitseis van artikel 6:163 BW. Het oordeel van de Centrale Raad komt er volgens hen op neer dat de geschonden norm slechts betrekking heeft op een aanspraak op uitkering en dus niet strekt ter bescherming tegen schade bestaande uit loonderving. Zij zijn van mening dat dit oordeel weinig met causaal verband te maken heeft, terwijl de Raad zijn oordeel wel stoelt op het ontbreken van causaal verband. Hoewel het criterium van de aard en strekking van een besluit ervoor kan zorgen dat de rechter schade uitsluit die in een te ver verwijderd verband staat met het onrechtmatige besluit, kan dit naar hun mening ook worden bereikt door toepassing van artikel 6:98 BW. Zij zijn zelf overigens van mening dat in de onderhavige gevallen van onjuiste arbeidsongeschiktheidsoordelen geen sprake is van een te ver verwijderd verband. Van Rossum en De Witte-van den Haak concluderen dat een ambtenaar met betrekking tot het vaststellen van causaal verband beter af is bij de burgerlijke rechter. ${ }^{\mathbf{3 0 1}}$

Ook Schlössels meent dat met de verwijzing naar aard en strekking van het vernietigde besluit de Centrale Raad van Beroep toepassing geeft aan de relativiteitsleer. Volgens Schlössels lijkt het erop dat het bestuursrecht een koppeling maakt tussen causaliteit en relativiteit. Deze leer is in het civiele recht echter verworpen. Schlössels stelt de vraag of, en zo ja in hoeverre, het bestuursrechtelijke aansprakelijkheidsrecht in dit verband terecht afwijkt van het civiele recht. ${ }^{302}$

Schueler en Van Ettekoven schrijven uitgebreid over de betreffende jurisprudentie van de Centrale Raad van Beroep met betrekking tot de onjuiste arbeids(on)geschiktheidsoordelen. Zij menen dat de Centrale Raad in deze uitspraken in feite oordeelt dat de gestelde schade in een te ver verwijderd verband staat tot het onrechtmatige besluit om aan het bestuursorgaan te kunnen worden toegerekend en in dat kader gewicht toekent aan het uitgangspunt dat een uitkeringsbesluit naar aard en strekking slechts ziet op de aanspraak op uitkering. De auteurs vragen zich af of de Raad hiermee een nieuwe factor heeft willen toevoegen aan de bekende afwegingsfactoren van Brunner. Schueler en Van Ettekoven wijzen erop dat bij hantering dit criterium de niet eenvoudig te beantwoorden vraag rijst op welke gevolgen een publiekrechtelijk besluit naar zijn aard en strekking is gericht. De hier te maken keuze raakt ook volgens Schueler en Van Ettekoven aan toepassing van de relativiteitsleer. Naar hun mening heeft de keuze een rechtspolitiek karakter. Zij raden aan om hier de criteria van Brunner toe te passen, maar benadrukken dat 
het mogelijk is dat de Centrale Raad van Beroep met toepassing van deze criteria tot dezelfde eindconclusie zou zijn gekomen over het antwoord op de vraag of de geclaimde schade kan worden toegerekend aan het onrechtmatige besluit als via het criterium van 'aard en strekking van het vernietigde besluit'. Hantering van de deelregels van Brunner biedt volgens hen echter de mogelijkheid de rechtspraak inzake toerekening te nuanceren en inzichtelijker te maken. ${ }^{\mathbf{3 0 3}}$ Schueler geeft aan dat de Centrale Raad van Beroep aan de afwegingsfactoren in het kader van de toerekening een nieuwe factor heeft toegevoegd door ook de aard en strekking van het vernietigde besluit van belang te achten. De gevolgen die feitelijk aan een besluit worden verbonden, voldoen niet aan het juridische causaliteitscriterium indien zij niet behoren tot de gevolgen waarop het besluit naar aard en strekking is gericht. Volgens Schueler wordt de causaliteitseis hierdoor wel erg beperkend toegepast in de uitspraken over aansprakelijkheid van de uitkeringsinstantie voor onjuiste arbeids(on)geschiktheidsoordelen. De beslissingen van de werkgever zijn vaak een voorzienbaar gevolg van het uitkeringsbesluit, zodat het naar zijn mening wel ver gaat om het causale verband zonder meer afwezig te achten. Een besluit is gericht op een bepaald rechtsgevolg, maar kan ook neveneffecten kan hebben. De vraag is volgens Schueler of deze neveneffecten als gevolg van het besluit aan het bestuursorgaan kunnen worden toegerekend. Hij concludeert dat de jurisprudentie ervoor lijkt te hebben gekozen om alleen de gevolgen waarop het besluit is gericht daaraan toe te rekenen in de zin van artikel 6:98 BW en neveneffecten niet. ${ }^{304}$

\section{Beoordeling en conclusie}

De Centrale Raad van Beroep laat bij beantwoording van de toerekeningsvraag 'de aard en de strekking van het vernietigde besluit' meewegen als toerekeningsfactor. De deelregels van causaliteit van Brunner kennen in het kader van de aard van de aansprakelijkheid belang toe aan beschermingsdoelen strekking, alsmede beschermingsomvang van de geschonden norm. ${ }^{\mathbf{3 0 5}} \mathrm{Naar}$ mijn mening sluit de betreffende jurisprudentie van de Centrale Raad daarbij aan. ${ }^{\mathbf{3 0 6}}$ Ik vind derhalve niet dat de Centrale Raad hierdoor causaliteit en relativiteit verwart. Wel hebben beide onderwerpen mijns inziens te maken dezelfde soort juridische vragen en aspecten, zodat zij elkaar op dit punt zullen raken.

Het valt mij op dat de Centrale Raad van Beroep meestal niet duidelijk maakt welke invloed de aard en strekking van het vernietigde besluit hebben op het toerekeningsoordeel in het concrete geval. Hierdoor bieden de uitspraken geen inzicht in de gedachtegang van de Centrale Raad omtrent de toerekening. Door in het concrete geval aan te geven welke betekenis en welk gewicht hij toekent aan de aard en strekking van het vernietigde besluit zou de Raad naar mijn mening zijn toerekeningsoordelen begrijpelijker en inzichtelijker maken. In de uitspraken waarin de werknemer inkomensschade lijdt, omdat hij door de uitkeringsinstantie ten onrechte arbeidsongeschikt wordt verklaard, geeft de Raad wel duidelijk de rol en betekenis van de aard en strekking van het vernietigde besluit als toerekeningsfactor aan. Bij zijn oordeel dat in dit geval geen causaal verband bestaat, acht hij van doorslaggevende betekenis dat het vernietigde besluit naar zijn aard en strekking slechts ziet op een aanspraak op uitkeringen krachtens de AAW en WAO.

Het oordeel van de Raad lijkt erop neer te komen dat alleen toerekenbaar is de 
schade, die voortvloeit uit de aanspraak op een uitkering, omdat dit het rechtsgevolg is waarop het besluit is gericht. ${ }^{\mathbf{3 0}}$ Dit betekent dat in deze gevallen alleen zogenaamde 'directe' schade voor vergoeding in aanmerking komt. Een dergelijke vergaande beperking van de omvang van de schadevergoedingsverplichting komt naar mijn weten op andere terreinen van het aansprakelijkheidsrecht niet voor. Gevolgschade komt als regel wel voor vergoeding in aanmerking, tenzij het in een te ver verwijderd verband staat tot de onrechtmatige daad. Uit de motivering van de Centrale Raad blijkt mij ook niet waarom hij deze afwijking nodig, dan wel gerechtvaardigd, acht. De inkomensschade van de werknemer is mijns inziens zeer goed te voorzien is en staat in ieder geval naar 'civiele' maatstaven niet in een te ver verwijderd verband met het onjuiste keuringsbesluit. ${ }^{\mathbf{3 0 8}} \mathrm{Mij}$ lijkt dat voor deze afwijking van de gebruikelijke toepassing van artikel 6:98 BW, waardoor zo een vergaande beperking van de omvang van de schadevergoedingsplicht ontstaat, een nadere verklaring op zijn plaats is. Dit geldt te meer nu de Centrale Raad in zijn uitspraken aangeeft aan te sluiten bij het civiele schadevergoedingsrecht en artikel 6:98 BW. Ik begrijp niet waarom aard en strekking van juist deze besluiten tot de genoemde conclusie leiden. Met andere woorden: naar mijn mening kan de motivering van de uitspraken de beslissing tot het ontbreken van causaliteit niet dragen. Ik zie ook niet direct een reden voor de vergaande beperking, behalve misschien de algemene wens om de overheidsaansprakelijkheid te beperken. ${ }^{309}$

Overigens heeft de Centrale Raad wel aansprakelijkheid van de uitkeringsinstantie aangenomen in de omgekeerde situatie dat een werknemer ten onrechte arbeidsgeschikt was verklaard en daardoor schade leed. Aard en strekking van het besluit leiden bij onjuiste arbeids(on)geschiktheidsoordelen dus niet altijd tot de conclusie dat causaal verband ontbreekt. Dit hangt volgens de Raad af van de omstandigheden van het concrete geval.310

De vraag blijft welke rol de aard en de strekking van het vernietigde besluit in het algemeen spelen bij het toerekeningsoordeel. Een algemene beperking tot vergoeding van de schade, die voortvloeit uit de rechtsgevolgen waarop het vernietigde besluit is gericht, zou betekenen dat bij besluitenaansprakelijkheid alleen nog directe schade voor vergoeding in aanmerking komt. Zelf vind ik dat door te bepalen dat alleen directe schade voor vergoeding in aanmerking komt het causaliteitsvereiste zonder goede - juridische - reden te nauw zou worden genomen.

\section{Jurisprudentie}

In paragraaf 6.2.2. bleek dat de bestuursrechter regelmatig schadevorderingen afwijst omdat de schade volgens hem wordt veroorzaakt door andere omstandigheden dan het vernietigde besluit. In paragraaf 6.2.3. kwam aan de orde dat de Centrale Raad van Beroep de aard en strekking van het vernietigde besluit als toerekeningsfactoren hanteert.

Het valt op dat in de bestuursrechtelijke jurisprudentie over het vereiste van toerekening de (overige) toerekeningsfactoren van Brunner nauwelijks een rol spelen. Er is in het overgrote deel van de uitspraken geen sprake van een multifactor benadering. De bestuursrechter beoordeelt in het algemeen niet of aan de hand van al deze factoren, in onderlinge verhouding bezien, voldaan is aan het vereiste van toerekening. 
Vaak motiveert de bestuursrechter ook niet uitdrukkelijk op grond van welke omstandigheden hij tot zijn oordeel komt dat de schade al dan niet aan de onrechtmatige daad kan worden toegerekend. Hierdoor is het lastig te achterhalen welke factoren en omstandigheden hij van belang acht voor zijn toerekeningsoordeel.

De Centrale Raad van Beroep beantwoordt bijvoorbeeld de toerekeningsvraag ontkennend in een zaak waarin de benadeelde jegens de uitkeringsinstantie vergoeding vordert van de proceskosten, die hij heeft gemaakt in een procedure tegen zijn voormalige werkgever om zijn ontslag aan te vechten. ${ }^{\mathbf{1 1 1}} \mathrm{De}$ onderliggende feiten zijn als volgt. Nadat zijn arbeidsovereenkomst is beëindigd, vraagt de oud-werknemer een werkeloosheidsuitkering aan. Deze wordt door de uitkeringsinstantie geweigerd wegens verwijtbare werkenloosheid, omdat de voormalige werknemer akkoord is gegaan met zijn ontslag. Het bestuursorgaan is van mening dat als de werknemer dit niet had gedaan, hij nog in dienst had kunnen blijven bij zijn voormalige werkgever. De oud-werknemer roept daarop alsnog de nietigheid van zijn ontslag in en maakt tevens bezwaar tegen de weigering van zijn uitkering. In bezwaar handhaaft de uitkeringsinstantie de weigering, primair omdat betrokkene niet werkeloos is geworden nu hij als gevolg van het inroepen van de nietigheid van het ontslag recht op loondoorbetaling heeft en subsidiair omdat hij verwijtbaar werkloos is geworden. Vervolgens dagvaart de oud-werknemer zijn voormalige werkgever en vordert nietigheid van het aan hem verleende ontslag. Tevens vecht hij de beslissing op bezwaar aan. De bestuursrechter vernietigt de weigering tot verlening van de werkeloosheidsuitkering. De civiele rechter wijst daarna de vordering tot nietigheid van het ontslag tegen de voormalige werkgever af. De uitkeringsinstantie laat vervolgens zijn standpunt dat de werknemer verwijtbaar werkeloos is geworden varen en kent hem alsnog een uitkering toe. Dit gebeurt op basis van informatie van de werkgever dat hij een verzoek tot ontbinding van de arbeidsovereenkomst zou hebben ingediend indien zijn werknemer niet zou hebben ingestemd met de beëindiging van het dienstverband. De oudwerknemer vordert daarop schadevergoeding van de uitkeringsinstantie, bestaande uit kosten van achteraf onnodig gebleken civiele procedures tegen zijn voormalig werkgever. Het geding in hoger beroep beperkt zich tot de vraag of de schade die betrokkene heeft geleden als gevolg van de onrechtmatige besluiten aan de uitkeringsinstantie kan worden toegerekend. Dit is volgens de Raad niet het geval:

"hij onderschrijft het oordeel van de rechtbank dat het voeren van een civielrechtelijke procedure tegen de werkgever over de rechtmatigheid van het ontslag voor appellant niet noodzakelijk was om de besluiten van het Uwv waarbij hem een WW-uitkering is onthouden, te kunnen aanvechten, terwijl inhoud en strekking van die besluiten daartoe ook geen enkele aanleiding gaven."

Naast de aard en de strekking van het besluit speelt dus volgens de Centrale Raad ook een rol dat het voeren van de civielrechtelijke procedure niet noodzakelijk was om de besluiten te kunnen aanvechten.

Ook in de volgende zaak speelt de noodzakelijkheid c.q. vrijwilligheid van de gemaakte kosten een rol bij de vraag of deze kunnen worden toegerekend. Indien een werkgever door een onjuiste beslissing van de uitkeringsinstantie ten 
onrechte aan zijn werknemer loon doorbetaalt, komen alleen de volgens de wet of CAO verplichte betalingen voor vergoeding in aanmerking. Loon dat vrijwillig is betaald kan niet aan het onrechtmatige besluit worden toegerekend. Een werkgever heeft schade heeft geleden doordat de uitkeringsinstantie hem ten onrechte de verplichting had opgelegd het loon van een werknemer door te betalen wegens onvoldoende inspanning van de werkgever tot re-integratie van de werknemer. De werkgever had aan de werknemer 100\% van zijn loon doorbetaald, terwijl hij wettelijk maar verplicht was tot betaling van $70 \%$ van het loon. De Raad is om die reden van mening dat slechts 70\% van het als gevolg van het onrechtmatige besluit doorbetaalde loon aan de uitkeringsinstantie kan worden toegerekend..$^{\mathbf{3 1 2}}$

Een bijzondere redenering omtrent de toerekening wordt gevolgd in de navolgende zaak. Betrokkene ontvangt een nabestaandenuitkering. Als gevolg van een auto-ongeval raakt zij arbeidsongeschikt en krijgt zij een arbeidsongeschiktheidsuitkering. Om deze reden wordt zij door de betreffende uitkeringsinstantie gedeeltelijk gekort op haar nabestaandenuitkering. Later wordt haar nabestaandenuitkering nogmaals naar beneden bijgesteld. Het oorspronkelijke besluit was derhalve onjuist. Zij stelt schade te hebben geleden, doordat het onjuiste besluit ertoe heeft geleid dat zij bij de vaststellingsovereenkomst inzake de letselschade met betrekking tot het autoongeval een te laag bedrag is overeengekomen, omdat zij was uitgegaan van een te hoog bedrag van de nabestaandenuitkering. Volgens de Raad is niet voldaan aan het vereiste van toerekening:
"Evenals de rechtbank is de Raad van oordeel dat de door appellante gevorderde schade niet kan worden toegerekend aan het onrechtmatige besluit van 14 juni 2004. Daartoe overweegt de Raad dat appellante [...] door de Svb uitgebreid is geïnformeerd over de op haar van toepassing zijnde regelgeving, zodat het haar redelijkerwijs duidelijk had kunnen zijn dat het daarvan afwijkende besluit van 14 juni 2004 onjuist was en niet als uitgangspunt kon dienen voor de onderhandelingen met Achmea over de vergoeding van letselschade." ${ }^{313}$

Volgens de Raad is dus niet voldaan aan het toerekeningsvereiste, omdat de benadeelde had kunnen weten dat het besluit onjuist was, nu het bestuursorgaan haar eerder had gewezen op de van toepassing zijnde regelgeving. De Raad wijst het schadeverzoek derhalve af, omdat hij vind dat de schade aan de benadeelde zelf is te wijten. Deze overweging vind ik niet erg overtuigend. Voor hetzelfde geld waren immers de inlichtingen onjuist. Indien de Raad dergelijke schade niet voor vergoeding in aanmerking wil laten komen, zou hij dit naar mijn mening beter kunnen motiveren met de overweging dat de schade in dit geval te ver verwijderd is van de onrechtmatige daad.

Ten slotte bestaan ook uitspraken, waarin de conclusie dat niet is voldaan aan het toerekeningsvereiste, niet (expliciet) wordt toegelicht en blijkt ook uit de uitspraken zelf niet (impliciet) welke factoren bij dit oordeel een rol hebben gespeeld..$^{314}$

\section{Literatuur}

Met betrekking tot de rechtspraak van de Centrale Raad van Beroep concluderen 
Schueler en Van Ettekoven dat de Centrale Raad nog moeite heeft met de invulling van de toerekening naar redelijkheid, omdat de uitkomsten betrekkelijk rigide, soms digitaal (alles of niets) zijn en niet zelden tot het oordeel leiden dat de gestelde schade niet aan het onrechtmatige besluit kan worden toegerekend. De auteurs vragen zich af of daarmee recht wordt gedaan aan de in het geding zijnde belangen van burgers die schade leiden door onrechtmatige overheidsbesluiten en of het niet beter kan, bijvoorbeeld door meer aansluiting te zoeken bij het burgerlijke recht en meer specifiek bij de benadering van Brunner. Het nut van de deelregels van causaliteit van Brunner is volgens Schueler en Van Ettekoven vooral dat beslissingen over toerekening er beter door kunnen worden gemotiveerd, waardoor ze ook beter controleerbaar worden. Het maakt de toerekening van schade doorzichtiger en beslissingen daarover kunnen rationeel worden verantwoord. Het systeem beoogt bovendien bij te dragen aan toerekeningsbeslissingen die als billijk worden ervaren, dat wil zeggen aansluiten bij hetgeen in de samenleving als rechtvaardig wordt ervaren. Het is de auteurs niet duidelijk waarom de Centrale Raad van Beroep een eigen causaliteitsleer zou moeten ontwikkelen. Naar hun mening zou aansluiting bij de civielrechtelijke leer van de redelijke toerekening op het terrein van de Raad heel goed mogelijk zijn en een heldere rechtsontwikkeling bevorderen. ${ }^{\mathbf{1 1 5}}$ Ook Kortmann, Van Maanen en Schlössels valt het op dat de criteria van Brunner nauwelijks lijken te spelen in de jurisprudentie van de Centrale Raad van Beroep over het causaal verband. ${ }^{316}$ Van Maanen en Schlössels vinden dat er bij besluitenaansprakelijkheid meer aandacht zou moeten zijn voor de leer van de toerekening naar redelijkheid van art. 6:98 BW. Zij wijzen op de krampachtige en zuinige toepassing door bestuursrechters van deze leer. Volgens hen zou er systematisch aandacht moeten worden besteed aan een aanvaardbare invulling van het causaliteitsvereiste en moeten gekunstelde causaliteitsredeneringen worden voorkomen. $\mathrm{Zij}$ hebben de indruk dat de bestuursrechters maar wat doen om het bestuur te beschermen.317

\section{Beoordeling en conclusie}

Met betrekking tot de toerekening lijkt in sommige zaken het feit dat de schade bestaat uit kosten, die niet noodzakelijkerwijs uit het onrechtmatige besluit voortvloeien, een factor te zijn bij het oordeel dat deze niet kan worden toegerekend. Vaak blijkt uit de uitspraak echter niet duidelijk op welke factoren het toerekeningsoordeel gebaseerd is. Opvallend vind ik dat de voorzienbaarheid van de schade en de aard van de schade bijna nooit worden genoemd in de toerekeningbeslissingen van de bestuursrechter, terwijl deze factoren in de rechtspraak over aansprakelijkheid van private partijen juist erg belangrijk zijn. In de huidige bestuursrechtspraak spelen dus, naast het feit dat de schade wordt veroorzaakt door andere omstandigheden dan het onrechtmatige besluit en de aard en strekking van het besluit, nauwelijks andere toerekeningsfactoren een rol.

Het zou wat mij betreft goed zijn als meer factoren (zichtbaar) van belang zouden worden bij het toerekeningsoordeel van de bestuursrechter. Door te differentiëren kan beter recht worden gedaan aan de omstandigheden van het concrete geval. Ik stel mij voor dat dit zal leiden tot genuanceerdere toerekeningsbeslissingen. Dit zal mijns inziens ook de acceptatie van de uitspraken ten goede kunnen komen. 
Om dit te bewerkstelligen kan de bestuursrechter naar mijn mening het beste (meer) aansluiting zoeken bij de factoren van toerekening van Brunner. ${ }^{\mathbf{3 1 8}} \mathrm{Op}$ die manier heeft hij het voordeel van een bekend, bestendig en goed ontwikkeld stelsel. De toerekeningsfactoren van Brunner zijn bovendien goed bruikbaar bij besluitenaansprakelijkheid. Het is ook denkbaar dat het bestuursrecht, naast de factoren van Brunner, nog eigen toerekeningsfactoren ontwikkelt. Artikel 6:98 BW biedt die ruimte. Een belangrijke reden voor het invoeren van dit artikel was immers dat de rechter verplicht en ook in de gelegenheid is zijn beslissing te motiveren met de werkelijke overwegingen die daaraan ten grondslag liggen. Het toerekeningsvereiste lijkt mij daarom bij uitstek de plek om openlijk en kenbaar rekening te houden met het feit dat het gaat om aansprakelijkheid van de overheid en dus de bijzondere positie van de overheid in het aansprakelijkheidsrecht uitdrukkelijk mee te wegen.

\section{Conclusie en afsluiting}

Dit onderzoek was erop gericht te bekijken in hoeverre de toepassing van het criterium van causaal verband bij besluitenaansprakelijkheid afwijkt van de toepassing ervan bij andere onrechtmatige daden en wat daarvoor de reden kan zijn. De afwijkende toepassing blijkt zich hoofdzakelijk voor te bij de bestuursrechter.

Het causaliteitsvereiste bevat twee elementen. Ten eerste dient sprake te zijn van een feitelijk causaal verband. Hier is sprake van als er een 'condicio sine qua non verband' bestaat tussen de onrechtmatige daad en de schade. Ten tweede geldt de toerekeningsleer van artikel 6:98 BW om het causaal verband nader te bepalen. Dit betreft het juridische causaal verband.

De eerste conclusie van het onderzoek is dat de bestuursrechtspraak vaak afwijkt van deze systematiek door geen onderscheid te maken tussen beide elementen. Hierdoor blijft soms onduidelijk waarop het causaliteitsoordeel gebaseerd is. Aansluiting bij het civiele recht lijkt mij hier aan te bevelen. Dit komt mijns inziens de rechtseenheid en rechtszekerheid ten goede.

Voor beide aspecten van causaal verband geldt vervolgens dat bij besluitenaansprakelijkheid op bepaalde punten wordt afgeweken van de gebruikelijke toepassing ervan.

Met betrekking tot het feitelijk causaal verband en het bewijs daarvan zijn de afwijkingen niet wereldschokkend. Bovendien zijn deze steeds goed te verklaren door de afwijkende feitelijke situatie bij besluiten op dat punt.

Dit ligt anders bij de toepassing van artikel 6:98 BW. Het toerekeningsvereiste betreft zoals gezegd een rechtsvraag en bakent de omvang van de aansprakelijkheid nader af.

De uitkomst van de causaliteitstoets wijkt in de individuele bestuursrechtzaken mijns inziens vaak af van de gebruikelijke toepassing van de toerekeningsleer en de causaliteitsregels van Brunner. Het resultaat hiervan is dat de juridische causaliteit bij besluitenaansprakelijk in die gevallen veel nauwer wordt genomen. Bij besluitenaansprakelijkheid wordt de schadeclaim namelijk afgewezen als een burger handelt op basis van een onrechtmatig besluit, omdat de schade dan niet zou worden veroorzaakt door dit onrechtmatige besluit. De Centrale Raad van Beroep laat bij beantwoording van de toerekeningsvraag tevens de aard en de strekking van het vernietigde besluit meewegen als toerekeningsfactor. 
Dit leidt ertoe dat de bestuursrechter schadevorderingen afwijst, omdat de vorderingen niet voldoen aan het toerekeningsvereiste, terwijl de geleden schade voorzienbaar is en naar 'civiele' maatstaven niet in een te ver verwijderd verband staat tot het onrechtmatige besluit. De bestuursrechtelijke benadering zorgt ervoor dat alleen directe schade voor vergoeding in aanmerking komt en dat gevolgschade van vergoeding wordt uitgesloten. Op andere terreinen van het aansprakelijkheidsrecht komt gevolgschade als regel wel voor vergoeding in aanmerking, tenzij deze schade in een te ver verwijderd verband staat tot de onrechtmatige daad. Het geconstateerde verschil is dus een vergaande beperking van de omvang van de schadevergoedingsverplichting, die afwijkt van de 'civiele' toepassing van artikel 6:98 BW. De bestuursrechter geeft in zijn uitspraken geen reden voor deze afwijking van het aansprakelijkheidsrecht. Ik kan hiervoor ook geen goede (juridische) reden bedenken, behalve de algemene wens om de overheidsaansprakelijkheid te beperken. Ik vind de betreffende uitspraken onbevredigend, omdat ze wat mij betreft onvoldoende recht doen aan het feit dat het onrechtmatige besluit feitelijk wel degelijk in meer of mindere mate heeft bijgedragen aan het ontstaan van de schade. Doordat de bestuursrechter weigert de fouten van de overheid in juridisch opzicht toe te rekenen aan de schade, zijn deze fouten voor de overheid blijkbaar gratis. Een genuanceerder resultaat zou worden behaald met een proportionele aansprakelijkheid van de overheid in deze gevallen. Voor het percentage van aansprakelijkheid zou de rechter dan kunnen aansluiten bij de mate waarin het onrechtmatige besluit al dan geen keuzevrijheid tot handelen dan wel nalaten laat. Een percentage van $100 \%$ is wat mij betreft gerechtvaardigd als het vernietigde besluit verplicht tot bepaalde handelingen of nauwelijks ruimte om anders te handelen dan is gedaan. Een lager percentage kan worden gehanteerd indien het onrechtmatige besluit veel vrijheid laat. Deze verdeling hangt ook samen met de voorzienbaarheid van de schade. Wanneer de schade mede een gevolg is van een omstandigheid die aan de benadeelde wordt toegerekend, kan de schade in overeenstemming met artikel 6:101 BW naar rato worden verdeeld tussen degene die aansprakelijk is uit onrechtmatige daad en de betreffende benadeelde.

Het voorgestelde systeem wijkt inderdaad af van de toepassing van artikel 6:98 BW bij feitelijke handelingen en van het civiele recht, maar dit geldt zoals gezegd ook voor de huidige bestuursrechtspraak. Nu de bestuursrechter er in deze gevallen blijkbaar moeite mee heeft als de overheid voor alle schade zou opdraaien, doet een proportionele toerekening mijns inziens meer recht aan het feit dat de overheid een fout heeft gemaakt, waardoor schade is ontstaan. De rechtvaardiging van de geconstateerde afwijking van het civiele recht kan alleen worden gezocht in het feit dat het gaat om besluitenaansprakelijkheid en, meer specifiek, de wens om de overheidsaansprakelijkheid niet te ruim te nemen. In de bestuursrechtspraak spelen naast het feit dat de schade wordt veroorzaakt door andere omstandigheden dan het onrechtmatige besluit en de aard en strekking van het besluit nauwelijks andere toerekeningsfactoren een rol. Genuanceerdere rechtspraak zal naar mijn mening ook ontstaan als de bestuursrechter meer factoren zou betrekken bij zijn toerekeningsoordeel en daardoor beter kan differentiëren. Hiervoor kan hij het beste aansluiten bij de bekende regels van Brunner. Ook is het denkbaar dat de rechter, naast de regels van Brunner, eigen toerekeningsfactoren ontwikkelt speciaal voor besluitenaansprakelijkheid. Artikel 6:98 BW biedt mijns inziens voldoende ruimte om rekening te houden de bijzondere positie van de overheid in het 
aansprakelijkheidsrecht.

Ten slotte kan in het algemeen worden gezegd dat de motivering van het oordeel over de toerekening vaak summier is. Hierdoor wordt de gedachtegang van de rechter daaruit niet inzichtelijk. Dit maakt de toerekeningsbeslissingen mijns inziens onvoorspelbaar. Als de bestuursrechter zijn oordeel over de toerekening nader zou onderbouwen in die zin dat hij in het concrete geval duidelijker aangeeft welke factoren waarom en op welke wijze een rol spelen dan zou dit zijn beslissing naar mijn mening begrijpelijker maken. Uiteindelijk zullen dan kenbare deelregels van causaliteit bij besluitenaansprakelijkheid ontstaan, waardoor de rechtszekerheid toeneemt. Dit sluit aan bij de bedoeling van de wetgever met artikel 6:98 BW dat dit artikel zou leiden tot rechterlijke uitspraken, waarin uitdrukkelijk zou blijken op grond van welke argumenten de rechter daadwerkelijk tot zijn conclusie omtrent de toerekening is gekomen.

\section{Noten}

1 Ook C.N.J. Kortmann, Onrechtmatige overheidsbesluiten (diss. UU), Deventer: Kluwer 2006, p. 31. De Centrale Raad van Beroep doet dit expliciet. Zie bijvoorbeeld: CRvB 18 juli 1997, $A B$ 1997, 358; CRvB 14 augustus 2001, $J B$ 2001, 258; CRvB 14 maart 2002, $A B$ 2002, 238; CRvB 18 december 2009, LJN BK7096; CRvB 16 juni 1994, TAR 1994, 177; CRvB 6 oktober 1994, TAR 1994, 243; CRvB 20 april 2000, TAR 2000, 90; CRvB 25 mei 2000, TAR 2000, 96; CRvB 19 februari 2009, JB 2009, 103; CRvB 7 april 1999, JB 1999, 124 en CRvB 11 februari 2000, $J B$ 2000, 77.

2 O.a. R.J.N. Schlössels, 'Van Gog/Nederweert op de helling, Over oneigenlijke en eigenlijke formele rechtskracht, rechtsmachtverdeling en een dreigend failliet van de besluitenaansprakelijkheid', $O \& A$ 2004, p. 70-84 (I); R.J.N. Schlössels, 'Weg met de besluitenaansprakelijkheid?', JBplus special 2004, p. 61-78 (II); G.E. Van Maanen, 'Schadevergoeding en besluiten. De ongelukkige consequenties van de blinde fixatie van het bestuursrecht op het besluitbegrip voor het schadevergoedingsrecht (en hoe daarvan bevrijd te raken)', Jbplusspecial 2004, p. 43 en NJB 2004, p. 787-794; G.E. Van Maanen en R.J.N. Schössels, 'Vernietigde besluiten en schadevergoeding, een MaastrichtsNijmeegse revolte?', Gst. nr. 7203 (2004), p. 139-144; H.Ph.J.A.M. Hennekens, Overheidsaansprakelijkheid op de weegschaal (afscheidsrede Nijmegen), Deventer: Kluwer 2001, p. 38; B. Schueler en B.J. Van Ettekoven, 'De Centrale Raad van Beroep en de aansluiting bij het civiele aansprakelijkheidsrecht', in: R.M. van Male e.a. (red.), Centrale Raad van Beroep 1903-20o3, Den Haag: Sdu 2003, p. 167; C.N.J. Kortmann, 'Schade na vernietiging en verlengde besluitvorming: een doos van pandora', NTB 2002, p. 96-106; C.N.J. Kortmann, 'Pandora revisited. Twee principiële Afdelingsuitspraken over causaal verband voor vernietigde besluiten', Gst. Nr. 7229 (2005), p. 257-267; B. Schueler, Schadevergoeding en de Awb, Aansprakelijkheid voor appellabele besluiten, Deventer: Kluwer 2005, p. 173; C.N.J. Kortmann, 'De uitkeringsinstantie gaat vrijuit. Waarom eigenlijk?’ JBplus 2003, p. 15-25; A.Q.C. Tak, Het Nederlands bestuursprocesrecht in theorie en praktijk, Nijmegen: Wolf Legal Publishers 2008, p. 1758-1769; A.Q.C. Tak, 'rechters met slappe knieën', NJB 2002, p. 14611462. 
3 Uitgangspunt is daarbij dat onnodige verschillen vermeden dienen te worden: zie M.W. Scheltema en M. Scheltema, Gemeenschappelijk recht. Wisselwerking tussen publiek- en privaatrecht, Deventer: Kluwer 2003, p. 2-4 en Kortmann 2006, p. 30-31.

4 HR 31 mei 1991, NJ 1993, 112.

5 Zie hierover ook: G.A. van der Veen, 'Aansprakelijkheid voor beslissingen in primo en causaal verband', NTB 2011, p. 298-306 en L.J.A. Damen, 'Nagtegaal als Pizzati op Ameland aangespoeld', $A A$ 2009, p. 244-251.

$6 \mathrm{ABRvS} 15$ december 2004, $J B$ 2005, 58 (Meerssen) en ABRvS 15 december 2004, LJN AR7587 (Ameland). Zie ook: B.P.M. Van Ravels, 'De Amelandse benzinestations. De koers van de Afdeling in het besluitenaansprakelijkheidsrecht', O\&A 2009, p. 19-20.

7 Zie hierover verder paragraaf 5.3.2.

8 HR 19 december 2008, JB 2009, 71. Ook: HR 13 oktober 2006, AB 2007, 270.

9 Anders C.N.J. Kortmann, 'Verstrikt in een woud van ficties. Over aansprakelijkheid voor vernietigde beslissingen op bezwaar en besluiten in primo naar aanleiding van het arrest Enschede/Gerridzen', NTBR 2008, nr. 1, p. 50-60. Kortmann meent naar aanleiding van het arrest van 13 oktober $2006(A B$ 2007, 270) dat de opvatting van de Hoge Raad inhoudt dat zolang van de rechtmatigheid van het besluit in primo moet worden uitgegaan, het vereiste causale verband tussen de (vernietigde) beslissing op bezwaar en de schade ontbreekt.

10 Zie o.a. R.J.B. Boonekamp, artikel 98 Boek 6 BW, aant. 9 (losbladige) en de daar genoemde literatuur en J. Spier e.a., Verbintenissen uit de wet en schadevergoeding (Studiereeks Burgerlijk Recht), Deventer: Kluwer 2006, p. 236. Anders: J.M. van Dunné, Verbintenissenrecht. Deel 2: onrechtmatige daad, overige verbintenissen, Deventer: Kluwer 2004, 399-459.

11 Zie bv. HR 5 juni 2009, LJN BH2815.

12 Boonekamp, artikel 98 Boek 6 BW, aant. 2.

13 HR 5 juni 2009, LJN BH2815 en HR 5 juni 2009, LJN BH2811.

14 Boonekamp, artikel 98 Boek 6 BW, aant. 9.

15 Zie HR 31 oktober 2008, LJN BFooo2. In dit arrest overwoog de Hoge Raad dat uit de overwegingen van het Hof niet duidelijk blijkt of zijn oordeel dat causaal verband ontbreekt betrekking heeft op het condicio sine qua non verband of het in artikel 6:98 BW bedoelde verband.

16 CRvB 3 maart 1999, JB 1999, 90. 
17 CRvB 20 april 2000, TAR 2000, 90.

18 ABRvS 15 december 2004, $J B$ 2005, 58 (Meerssen) en ABRvS, 15 december 2004, LJN AR7587 (Ameland). Zie over deze uitspraken ook paragraaf 5.

19 Ook Kortmann 2005, p. 260; Van Ravels 2009, p. 20

20 CRvB 1 november 2001, TAR 2002, 23; ABRvS 18 mei 1999, Gst. nr. 7102 (1999), p. 408-411. Ook: ABRvS 20 juni 2007, JB 2007, 150; ABRvS 6 november 2002, BR 2003, 608 .

21 Bijvoorbeeld in CRvB 19 mei 2009, LJN BI6o20; CRvB 18 juli 1997, $A B$ 1997, 358 en CRvB 17 juni 1998, JB 1998, 189.

22 Schlössels 2004(I), p. 70-84.

23 Kortmann 2005, p. 260.

24 Schueler en Van Ettekoven 2003, p. 165.

25 Zie paragraaf 4.1.

26 ABRvS 15 december 2004, $J B$ 2005, 58 (Meerssen) en ABRvS, 15 december 2004, LJN AR7587 (Ameland).

$27 \mathrm{ABRvS} 15$ december 2004, JB 2005, 58 (Meerssen). Idem ABRvS, 15 december 2004, $L J N$ AR7587 (Ameland). Het criterium wordt ook toegepast in: ABRvS 1 september 2004, JB 2004, 353.

$\mathbf{2 8}$ In eerdere jurisprudentie heeft de Afdeling wel het 'civiele' condicio sine qua non vereiste toegepast door te bekijken of ook indien een rechtmatig besluit zou zijn genomen de schade zich zou hebben voorgedaan: ABRvS 10 augustus 2000, $J B$ 2000, 271 en ABRvS 29 september 3002, JB 2004, 367.

29 Bij de bewijslevering is overigens wel van belang of uiteindelijk een rechtmatig besluit is genomen. Is dit het geval, dan is in beginsel aannemelijk dat zo'n besluit ook in plaats van het onrechtmatige besluit zou hebben kunnen worden genomen. Zie hierover paragraaf 5.3.2.

3o HR 1 april 2005, JB 2005, 136.

31 Gerechtshof Amsterdam 15 juni 2010, zaaknummer 200.034.466/o1. In cassatie is dit criterium niet bestreden, zie HR 23 december 2011, LJN BT7193. Zie over deze uitspraak verder paragraaf 5.2.3. Ook: Gerechtshof Arnhem, 22 september 2009, NJF 2009. 454 en Rechtbank Amsterdam (Voorzieningenrechter), 7 december 2006, $R F$ 2007, 17.

32 Het is vaste jurisprudentie dat bouwen voordat de bouwvergunning onherroepelijk is geworden voor risico komt van de bouwer: HR 29 april 1994, NJ 1997, 396. 
33 Advocaat-Generaal Keus gaat er in zijn conclusie bij HR 10 april 2009, $A B$ 2009, 320 in een zaak met dezelfde feiten als hier geschetst vanuit dat alleen sprake is van causaal verband met de vertragingsschade van de bouw indien ten tijde van de verlening van de onrechtmatige bouwvergunning een rechtmatige vergunning had kunnen worden verleend. Het arrest leidt ertoe dat de Gemeente Barneveld aansprakelijk is voor bedoelde vertragingsschade. De causaliteitsvraag komt in het arrest echter niet aan de orde. Zie ook: HR 1 oktober 1999, $A B$ 2000, 5 .

34 Kortmann 2005, p. 257-267.

35 Hij wijst daarbij op HR 28 juni 1985, NJ 1986, 356.

36 R.J.N. Schlössels, 'Overheidsaansprakelijkheid voor vernietigde besluiten. Een wondere wereld van juridische spinsels, wartaal en klassieke leerstukken?', in: C.J.M. Klaassen e.a. (red.), Aansprakelijkheid in beroep, bedrijf of ambt (Serie Onderneming en Recht, 25), Deventer: Kluwer 2003, p. 543; Schlössels 2004 (I), p. 70-84; Schlössels 2004 (II), p. 61-78.

37 Schlössels 2004 (I), p. 70-84. A.J. Akkermans, De 'omkeringsregel' bij het bewijs van causaal verband (oratie VU), Den Haag: Boom Juridische uitgevers 2002, p. 122.

38 Zie paragraaf 4.2.2.

39 Tak 2008, p. 1767-1769.

40 G.M.T. Berkel-Kikkert en E.G.J. Broekhuizen, 'Schadevergoeding bij onrechtmatige besluiten; de jurisprudentie op een rij (deel I)', Jbplus 2009, p. 44 .

41 Zie hierover paragraaf 5.2.

42 HR 23 juni 1989, NJ 1990, 441 en HR 7 december 2001, NJ 2002, 576.

43 HR 2 februari 1990, NJ 1991, 292 en HR 7 december 2001, NJ 2002, 576.

44 HR 2 februari 1990, NJ 1991, 292.

45 ABRvS 15 december 2004, $J B$ 2005, 58 (Meerssen). Idem ABRvS, 15 december 2004, LJN AR7587 (Ameland). Zie hierover paragraaf 5.1.2.

$46 \mathrm{ABRvS} 15$ december 2004, JB 2005, 54 (Meerssen). Idem ABRvS, 15 december 2004, LJN AR7587 (Ameland).

47 Bij de civiele rechter bestaat in dergelijke situaties in het geheel geen recht op schadevergoeding. De schadeclaim stuit af op de formele rechtskracht, omdat het besluit inhoudelijk overeind blijft. Zie HR 19 december 2008, JB 2009, 71.

48 Zie Kortmann 2005. Over onderbroken causaliteit zie paragraaf 5.1.2. 
49 HR 7 december 2001, NJ 2002, 576.

50 Zie ook Schueler 2005, 187.

51 HR 23 december 2011, LJN BT7193.

52 HR 2 februari 1990, NJ 1991, 292 en HR 7 december 2001, NJ 2002, 576.

53 Zie bijvoorbeeld N.S.J. Koeman, Overheidsaansprakelijkheid, administratieve of burgerlijke rechter, VAR-reeks 102, 1989 (preadvies), p. 204-207.

54 Schlössels 2003, p. 541-544. Kortmann 2002, p. 102-103. Zie ook Hof Den Haag 21 januari 1999, $N J$ 2000, 75. In deze uitspraak overweegt het Hof dat latere legalisering van een onterecht verleende bouwvergunning niet wegneemt dat aansprakelijkheid blijft bestaan voor dit onrechtmatige besluit. De uitspraak wordt besproken door Kortmann 2002, p. 102.

55 Kortmann 2002, p. 101 en Schlössels 2003, p. 541-544. Zie ook J.H.W. de Planque, Overheidsaansprakelijkheid, administratieve of burgerlijke rechter, VAR-reeks 102, 1989 (preadvies), p. 104-105.

56 Kortmann 2002, p.101; Schlössels, 2004(I), p. 70-84; Kortmann 2005, p. 258-259.

57 Kortmann 2002, p. 101; Schlössels 2003, p. 541-544.

58 Schlössels, 2004(I), p. 70-84.

59 Kortmann 2002, p. 102.

60 PG Awb II, p. 480.

61 Kortmann 2002, p. 103. Het artikel van Kortmann beperkt zich in principe tot de aansprakelijkheid van de gemeente voor schade die derden lijden door een onrechtmatige verlening van een bouwvergunning. Zijn opvattingen en conclusies lijken echter vrij algemeen te zijn.

62 Schlössels 2003, p. 541-544

63 Schlössels 2003, p. 541-544; Schlössels, 2004(I), p. 70-84; Schlössels 2004(II), p. 61-78.

64 Schlössels, 2004(I), p. 70-84. Ook: Tak 2008, p. 1763.

65 Tak 2008, p. 1763.

66 Tak, Toch maar de Hoge Raad volgen? Bestuursrechtelijke vernietiging en civiele onrechtmatigheid, Themis 2004-1, p.3-13 en Tak 2008, 1763. Zie ook: Hof Den Haag 21 januari 1999, NJ 2000, 75. 
67 Ook Kortmann 2005, p. 262-263.

68 C.J.M. Klaassen, Monografieën BW. Schadevergoeding: algemeen deel 2, Deventer: Kluwer 2007, nr. 20 en Boonekamp, artikel 98 Boek 6 BW, aant. 13.1.

69 PG boek 6, p. 346-347. Zie verder over artikel 6:99 BW bijvoorbeeld: Boonekamp, artikel 99 Boek 6 BW (losbladige) en Spier e.a. 2006, p. 266-269.

70 Zie bv. HR 19 januari 2001, NJ 2001, 524; HR 2 maart 2001, NJ 2001, 649; HR 23 november 2001, NJ 2002, 386; HR 23 november 2001, NJ 2002, 387; HR 29 november 2002, NJ 2004, 304 en HR 29 november 2002, NJ 2004, 305.

71 HR 29 november 2002, $N J$ 2004, 304 en HR 29 november 2002, $N J$ 2004, 305 .

72 HR 29 november 2002, NJ 2004, 304 en HR 29 november 2002, NJ 2004, 305 .

73 Zie voor een overzicht Giesen, 'De aantrekkingkracht van Loreley, over de opkomst en ondergang (?) van de omkeringsregel', in: Tien pennenstreken over personenschade. Bijdragen ter gelegenheid van het twintigste symposium van de vereniging van Letselschade Advocaten 2009, Den Haag: Sdu Uitgevers 2009, p. 69-86.

74 Zie Giesen 2009, p. 79; Spier e.a. 2006, p. 240.

75 Zie bv. HR 5 juni 2009, LJN BH2811 en HR 5 juni 2009, LJN BH2815.

76 HR 27 november 2009, LJN BH2162.

77 Voor een algemeen overzicht van verschil in bewijsrecht bij schadevorderingen wegens onrechtmatige besluiten zie: L. Di Bella en Y.E. Schuurmans, 'Schade als gevolg van een onrechtmatig besluit: vergoeding via het burgerlijk of het bestuursprocesrecht?', O\&A 2006, p. 88-105.

78 Di Bella en Schuurmans 2006, p. 91. Zie bijvoorbeeld: ABRvS 6 februari 2008, JB 2008, 61; ABRvS 23 juli 2003, AB 2003, 448; ABRvS 18 mei 1999, Gst. nr. 7102 (1999), p. 408-411 en ABRvS 20 juni 2007, JB 2007, 150.

79 ABRvS 26 januari 2005, JB 2005, 81.

80 Zie ook Schlössels in zijn noot bij deze uitspraak (ABRvS 26 januari 2005, JB 2005,81 . Hij vraagt zich bij het lezen van dit soort uitspraken steeds af wat civilisten hier nu van vinden.

81 ABRvS 20 juni 2007, JB 2007, 150.

82 CRvB 27 april 2006, JB 2006, 200 en CRvB 12 september 2002, JB 2002, 339 . 
83 CRvB 19 september 2002, JB 2002, 341. Deze zaak betrof overigens geen besluitenaansprakelijkheid, maar werkgeversaansprakelijkheid van de overheid voor ambtenaren. Voor werkgeversaansprakelijkheid geldt een criterium dat afwijkt van de algmene onrechtmatigedaadsnorm. Zie voor het criterium van werkgeversaansprakelijkheid van de overheid: CRvB 22 juni 2000, TAR 2000, 112; CRvB 9 augustus 2007, TAR 2008, 18; CRvB 8 juni 2006, TAR 2006, 139 en CRvB 12 maart 1998, TAR 1998, 78. De Centrale Raad heeft wel toepassing gegeven aan de omkeringsregel in zaken van werkgeversaansprakelijkheid: CRvB 5 september 2002, TAR 2003, 22 en CRvB 12 mei 2005, JB 2005, 200. Deze uitspraken zijn echter gedaan voordat de Hoge Raad in vergelijkbare gevallen van werkgeversaansprakelijkheid van civiele partijen proportionele aansprakelijkheid heeft aangenomen. Zie hierover paragraaf 5.4. In latere rechtspraak sluit de Centrale Raad aan bij deze rechtspraak van de Hoge Raad door in dergelijke zaken ook proportionele aansprakelijkheid aan te nemen: CRvB 9 april 2009, JB 2009, 168.

$84 \mathrm{CBb} 17$ april 2003, $A B$ 2003, 277.

85 Zie ook Kortmann, 'De omkeringsregel, lees eerst de gebruiksaanwijzing', O\&A 2004, p. 188-189.

86 HR 29 november 2002, NJ 2004, 304 en HR 29 november 2002, $N J$ 2004, 305. Zie paragraaf 5.3.1.

87 Zie Schlössels 2004(I), p. 70-84; Schlössels 2004(II), p. 61-78; Kortmann 2004; C.L.G.F.H. Albers, 'Overheidsaansprakelijkheid voor gebrekkig toezicht en ontoereikende handhaving', NTB 2004, p. 201-211 en Giesen, Toezicht en aansprakelijkheid, Deventer: Kluwer 2005, p. 204-211.

88 Albers 2004.

89 Kortmann 2004, p. 185-186.

90 Giesen 2005, p. 204-211.

91 Zie bijvoorbeeld Akkermans 2002, p. 123-135. De ratio van bewijsnood geldt mijns inziens eerder bij toepassing van het leerstuk van proportionele aansprakelijkheid: zie hierover paragraaf 5.4 .

92 HR 29 november 2002, NJ 2004, 304 en HR 29 november 2002, NJ 2004, 305. Zie paragraaf 5.3.1.

93 In gelijke zin Albers 2004.

$94 \mathrm{ABRvS} 15$ december 2004, JB 2005, 58 (Meerssen). Idem ABRvS, 15 december 2004, LJN AR7587 (Ameland). Deze uitspraken kwamen al aan de orde in paragraaf 3 , paragraaf 4.2.2. paragraaf 5.1.2. en paragraaf 5.2.2.

95 ABRvS 20 juni 2007, JB 2007, 150. 
96 Om deze reden kan er een procesbelang bestaan bij een bestuursrechtelijk oordeel over de rechtmatigheid van de beslissing op bezwaar, terwijl verder geen belang meer bestaat bij een oordeel over de inhoud van een besluit: ABRvS 17 juni 2009, $L J N$ BI8441. In deze zaak was een vergunning voor een wildwaterpark geweigerd. Hangende de procedure besloot de aanvrager af te zien van realisatie van het wildwaterpark, maar wenste wel schadevergoeding vanwege de volgens hem onterechte weigering van de vergunning. De vergunning was in het primaire besluit op andere gronden geweigerd dan in de beslissing op bezwaar. De Afdeling is van mening dat indien de beslissing op bezwaar rechtens juist is dit met zich brengt dat in beginsel aannemelijk is gemaakt dat ten tijde van het nemen van het primaire besluit de vergunning rechtmatig had kunnen worden geweigerd en dat daarom procesbelang bestaat.

97 HR 1 april 2005, JB 2005, 136. Zie over dit arrest ook paragraaf 5.1.2.

98 Vooral door Akkermans. Zie bijvoorbeeld: A.J. Akkermans, Proportionele aansprakelijkheid bij onzeker causaal verband (diss. Tilburg), Deventer: Kluwer 1997 en A.J. Akkermans, 'Theorie en praktijk van proportionele aansprakelijkheid', in: A.J. Akkermans, M.G. Faure en T. Hartlief (red.), Proportionele aansprakelijkheid, Den Haag: Boom juridische uitgevers 2000, p. 85-134. Zie verder over proportionele aansprakelijkheid bijvoorbeeld I. Giesen en T.F.E. Tjong Tjin Tai, Proportionele tendensen in het verbintenissenrecht: een rechtsgeleerde dialoog. (Preadvies voor de Vereniging voor Burgerlijk Recht), Deventer: Kluwer 2008.

99 Dit houdt in dat schadevergoeding kan worden verkregen voor de kans dat de schade zonder de onrechtmatige daad niet zou zijn geleden. Zie hierover bijvoorbeeld: Akkermans 1997, hoofdstuk 3 en C. Van Dijk, 'Onzeker causaal verband in de rechtspraak’, in: Akkermans, Faure en Hartlief 2000, p. 27-41.

100 Zie bijvoorbeeld D. Peeperkorn, 'Het feest van de gedaagden, kritiek op de proportionele leer', in: Akkermans, Faure en Hartlief 2000, p. 59-83.

101 Zie HR 31 maart 2006, RvdW 2006, 328 en 9 januari 2009, LJN BG4014; Hof Amsterdam (Handelskamer) 27 januari 2009, NJ 2009, 297 en Rechtbank Zwolle-Lelystad, 17 september 2008, JB 2008, 247. Jurisprudentie over het verlies van een kans: HR 24 oktober 1997, $N J$ 1998, 257; HR 19 januari 2007, $N J$ 2007, 63 en HR 16 februari 2007, RvdW 2007, 203.

102 HR 24 december 2010, LJN BO1799.

103 HR 24 december 2010, LJN BO1799.

104 CRvB 9 april 2009, JB 2009, 168. Zie ook noot 83.

105 Zie HR 31 maart 2006, RvdW 2006, 328 en 9 januari 2009, LJN BG4014.

106 Di Bella en Schuurmans 2006, p. 91. Zie bijvoorbeeld: ABRvS 6 februari 2008, JB 2008, 61; ABRvS 23 juli 2003, AB 2003, 448; ABRvS 18 mei 1999, Gst. nr. 7102 (1999), p. 408-411 en ABRvS 20 juni 2007, JB 2007, 150. 
107 ABRvS 26 januari 2005, JB 2005, 81.

108 Zie ook Schlössels in zijn noot bij deze uitspraak (ABRvS 26 januari 2005, $J B$ 2005, 81). Hij vraagt zich bij het lezen van dit soort uitspraken steeds af wat civilisten hier nu van vinden.

109 ABRvS 20 juni 2007, JB 2007, 150.

110 CRvB 27 april 2006, JB 2006, 200 en CRvB 12 september 2002, JB 2002, 339 .

111 CRvB 19 september 2002, JB 2002, 341. Deze zaak betrof overigens geen besluitenaansprakelijkheid, maar werkgeversaansprakelijkheid van de overheid voor ambtenaren. Voor werkgeversaansprakelijkheid geldt een criterium dat afwijkt van de algmene onrechtmatigedaadsnorm. Zie voor het criterium van werkgeversaansprakelijkheid van de overheid: CRvB 22 juni 2000, TAR 2000, 112; CRvB 9 augustus 2007, TAR 2008, 18; CRvB 8 juni 2006, TAR 2006, 139 en CRvB 12 maart 1998, TAR 1998, 78. De Centrale Raad heeft wel toepassing gegeven aan de omkeringsregel in zaken van werkgeversaansprakelijkheid: CRvB 5 september 2002, TAR 2003, 22 en CRvB 12 mei 2005, JB 2005, 200. Deze uitspraken zijn echter gedaan voordat de Hoge Raad in vergelijkbare gevallen van werkgeversaansprakelijkheid van civiele partijen proportionele aansprakelijkheid heeft aangenomen. Zie hierover paragraaf 5.4. In latere rechtspraak sluit de Centrale Raad aan bij deze rechtspraak van de Hoge Raad door in dergelijke zaken ook proportionele aansprakelijkheid aan te nemen: CRvB 9 april 2009, JB 2009, 168.

$112 \mathrm{CBb} 17$ april 2003, $A B$ 2003, 277.

113 Zie ook Kortmann, 'De omkeringsregel, lees eerst de gebruiksaanwijzing', O\&A 2004, p. 188-189.

114 HR 29 november 2002, NJ 2004, 304 en HR 29 november 2002, NJ 2004, 305. Zie paragraaf 5.3.1.

115 Zie Schlössels 2004(I), p. 70-84; Schlössels 2004(II), p. 61-78; Kortmann 2004; C.L.G.F.H. Albers, 'Overheidsaansprakelijkheid voor gebrekkig toezicht en ontoereikende handhaving', NTB 2004, p. 201-211 en Giesen, Toezicht en aansprakelijkheid, Deventer: Kluwer 2005, p. 204-211.

116 Albers 2004.

117 Kortmann 2004, p. 185-186.

118 Giesen 2005, p. 204-211.

119 Zie bijvoorbeeld Akkermans 2002, p. 123-135. De ratio van bewijsnood geldt mijns inziens eerder bij toepassing van het leerstuk van proportionele aansprakelijkheid: zie hierover paragraaf $5 \cdot 4$. 
120 HR 29 november 2002, $N J$ 2004, 304 en HR 29 november 2002, $N J$ 2004, 305. Zie paragraaf 5.3.1.

121 In gelijke zin Albers 2004.

122 ABRvS 15 december 2004, $J B$ 2005, 58 (Meerssen). Idem ABRvS, 15 december 2004, LJN AR7587 (Ameland). Deze uitspraken kwamen al aan de orde in paragraaf 3 , paragraaf 4.2.2. paragraaf 5.1.2. en paragraaf 5.2.2.

123 ABRvS 20 juni 2007, JB 2007, 150.

124 Om deze reden kan er een procesbelang bestaan bij een bestuursrechtelijk oordeel over de rechtmatigheid van de beslissing op bezwaar, terwijl verder geen belang meer bestaat bij een oordeel over de inhoud van een besluit: ABRvS 17 juni 2009, LJN BI8441. In deze zaak was een vergunning voor een wildwaterpark geweigerd. Hangende de procedure besloot de aanvrager af te zien van realisatie van het wildwaterpark, maar wenste wel schadevergoeding vanwege de volgens hem onterechte weigering van de vergunning. De vergunning was in het primaire besluit op andere gronden geweigerd dan in de beslissing op bezwaar. De Afdeling is van mening dat indien de beslissing op bezwaar rechtens juist is dit met zich brengt dat in beginsel aannemelijk is gemaakt dat ten tijde van het nemen van het primaire besluit de vergunning rechtmatig had kunnen worden geweigerd en dat daarom procesbelang bestaat.

125 HR 1 april 2005, JB 2005, 136. Zie over dit arrest ook paragraaf 5.1.2.

126 Voornamelijk van H.K. Köster, Causaliteit en voorzienbaarheid (oratie UvA), Zwolle: W.E.J. Tjeenk Willink 1963 en A.R. Bloembergen, Schadevergoeding bij onrechtmatige daad (diss. Utrecht), Deventer: Kluwer 1965, nr. 116 e.v.

127 PG boek 6, p. 342.

128 PG boek 6, p. 345 .

129 O.a. Spier e.a. 2006, p. 242 en Boonekamp, artikel 98 Boek 6 BW, aant. 26. 130 C.J.H. Brunner, 'Causaliteit en toerekening van schade', $V R$ 1981, p. 210217.

131 Spier e.a. 2006, p. 243.

132 Zie bv. HR 9 juni 1972, NJ 1972, 360; HR 21 maart 1975, NJ 1975, 372; HR 6 oktober 1995, NJ 1998, 190; HR 13 januari 1995, NJ 1997, 175 en HR 25 november 2005, NJ 2007, 141.

133 HR 8 februari 1985, NJ 1986, 136 en 137; HR 4 november 1988, NJ 1989, 741.

134 bijvoorbeeld: HR 4 november 1988, $N J$ 1989, 751. 
135 Boonekamp, artikel 98 Boek 6 BW, aant. 32.

136 Brunner 1981, p. 214.

137 HR 1 juli 1977, NJ 1978, 84. Ook: HR 2 oktober 1998, NJ 1998, 831.

138 Boonekamp, artikel 98 Boek 6 BW, aant. 32 en HR 1 juli 1977, NJ 1978, 84.

139 Brunner 1981, p. 212 en 214; T. Hartlief, 'Schadevergoedingsrecht', in Spier e.a. 2006, p. 244-245; Boonekamp, artikel 98 Boek 6 BW, aant. 29.1 en de daar genoemde literatuur.

140 Bijvoorbeeld HR 5 juni 2009, LJN BH2815.

141 HR 2 november 1979, $N J$ 1980, 77.

142 Zie HR 2 november 1979, NJ 1980, 77. Ook: Boonekamp, artikel 98 Boek 6 $B W$, aant. 29.3 en Hartlief in Spier e.a. 2006, p. 246.

143 Zie bijvoorbeeld: Hartlief in Spier e.a. 2006, p. 244-245; R.J.B. Boonekamp, 'Door de kat en de hond gebeten', in: Als een goed huisvader (Nieuwenhuisbundel), Deventer: Kluwer 1992, p. 99 e.v. en C.J.M. Klaassen, Risicoaansprakelijkheid (diss. Nijmegen), Zwolle: W.E.J. Tjeenk Willink 1991, hfdst. 5. Ook Brunner 1981, p. 215-216.

144 Brunner 1981, p. 216.

145 HR 8 februari 1985, NJ 1986, 137. Brunner 1981, p. 216; T. Hartlief, 'Letselschade en toerekening naar redelijkheid', $V R$ 1995, p. 161 e.v.; Hartlief in Spier e.a. 2006, p. 248 en Boonekamp, artikel 98 Boek 6 BW, aant. 30.

146 CRvB 14 maart 2002, $A B$ 2002, 238.

$147 \mathrm{ABRvS} 18$ november 2009, $A B$ 2010, 5 .

148 ABRvS 23 januari 2002, JB 2002, 69.

149 Bijvoorbeeld CRvB 28 augustus 2001, $J B$ 2001, 259; CRvB 7 april 1999, $J B$ 1999, 124 en CRvB 11 februari 2000, JB 2000, 77. In zijn noot bij deze laatste uitspraak wijst Smits erop dat vanuit puur privaatrechtelijk oogpunt er weinig op tegen is om in casu wel causaal verband aan te nemen. Er is volgens hem zelfs voldaan aan de eis van voorzienbaarheid, omdat voorzienbaar was dat intrekking van de uitkering zou leiden tot de schade.

150 CRvB 28 augustus 2001, JB 2001, 259.

151 CRvB 11 februari 2000, $J B$ 2000,77.

152 HR 6 april 2001, NJ 2001, 333. 
153 Kortmann 2003, p. 15-25.

154 Kortmann verwijst hiervoor naar CRvB 17 juni 1998, JB 1998, 189. Deze uitspraak wordt hierna onder c behandeld.

155 Noot bij CRvB 28 augustus 2001, JB 2002, 259 en Van Maanen 2004, p. 787-794.

156 Van Maanen 2004, p. 787-794.

157 Zie de noot bij CRvB 11 februari 2000, JB 2000, 77.

158 CRvB 21 juni 2005, JB 2005, 240.

159 O.a. HR 8 februari 1985, $N J$ 1986, 137.

160 Bijvoorbeeld wel een ruime toerekening in HR 1 juli 1993, NJ 1993, 667, waarin de zorgvuldigheidsnorm van goed werkgeverschap was geschonden. Daarentegen geen ruime toerekening in HR 2 november, $N J$ 1980, 77. In deze zaak ging het om een (verondersteld) onrechtmatige bejegening van een arts en zijn ziekenhuis jegens een vader wiens dochter in coma was geraakt tijdens een operatie.

161 CRvB 21 juni, JB 2005, 240.

162 CRvB 4 mei 2005, JB 2005, 179.

163 CRvB 19 mei 2009, LJN BI6020.

164 Dit geldt mijns inziens ook voor CRvB 18 juli 1997, $A B$ 1997, 358 waar het psychisch letsel volgens de Raad werd veroorzaakt door voorafgaand ontslag van de werkgever en het verleden van de benadeelde en dus niet door het onrechtmatige besluit. Zie over dit onderwerp ook paragraaf 4 .

165 ABRvS 31 maart 2000, JB 2000, 137.

$166 \mathrm{CRvB} 14$ augustus 2001, JB 2001, 258.

167 CRvB 17 juni 1998, JB 1998, 189.

168 ABRvS 6 februari 2002, $A B$ 2002, 257.

169 Van Maanen en Schlössels 2004, p. 139-144. Ook: Schlössels 2004 (I), p. 70-84 en Schlössels 2004 (II), p. 61-78.

170 Schlössels 2003, p. 537-541.

171 Hennekens sprak over de waarschijnlijkheidsleer: noot bij CRvB 17 juni 1999, $A B$ 1999, 348. 
172 Schlössels verwijst naar zie HR 7 november 1997, $A B$ 1998, 221: Schlössels 2003, p. 537-541. Ook: Schlössels 2004 (I), p. 70-84 en Schlössels 2004 (II), p. 61-78.

173 Hij wijst op ABRvS 1 juni 1999, JB 1999, 192; ABRvS 18 mei 1999, JB 1999, 215 en CRvB 28 augustus 2001, JB 2001, 259.

174 Schlössels, 2004 (II), p. 61-78. Ook Tak 2008, p. 1760-1762.

175 Schlössels, 2004 (I), p. 70-84 en Schlössels 2004 (II), p. 61-78. Ook Tak 2008, p. 1760-1762.

176 Schlössels 2004 (I), p. 70-84.

177 Schlössels 2004 (II), p. 61-78.

178 Ook Tak 2008, p. 1760-1762.

179 G.M.J.M. Jurgens, Bestuurlijk gedogen. Aanvaardbaarheid en gevolgen van bestuurlijk gedogen in het milieurecht en het ruimtelijk recht, Zwolle:

Tjeenk Willink 1996, p. 203 en G.M.T. Jurgens, 'Overheidsaansprakelijkheid bij gedogen?', NJB 2000, p. 1281.

180 Zie hierover paragraaf 4 .

$\mathbf{1 8 1}$ Alleen in de besproken zaak waarin niet werd gehandhaafd bij illegaal houden van bijen zou het condicio sine qua non verband misschien een punt van discussie kunnen zijn, omdat niet direct duidelijk is of ook bij correcte handhaving de schade ten gevolge van het illegaal houden van bijen al dan niet in gelijke mate - zou zijn geleden: ABRvS 18 november 2009, $A B$ 2010, 5 .

182 Zie bijvoorbeeld HR 23 september 1988, NJ 1989, 743 en HR 15 februari 1991, $A B$ 1991, 394 .

183 Zie paragraaf 5.4 .

184 Ook: Schueler en Van Ettekoven 2003, p. 166.

185 CRvB 14 maart 2002, $A B$ 2002, 238. Zie ook de annotator H.E. Bröring: hem lijkt deze eis te streng.

186 ABRvS 23 januari 2002, $J B$ 2002, 69. Zie ook CBb 29 juli 1997, $A B$ 1997,447 ('rechtstreeks en onmiddellijk'); ABRvS 18 mei 2005, LJN AT5690 ('rechtstreeks') en 18 november 2009, AB 2010, 5 ('rechtstreeks').

187 HR 2 oktober 1998, NJ 1998, 831.

188 Zelfs stagnatieschade wordt bijvoorbeeld niet als regel uitgesloten van vergoeding. Zie paragraaf 6.1. ad 2. en HR 1 juli 1977, $N J$ 1978, 84. Ook: HR 2 oktober 1998, NJ 1998, 831. 
189 Ook: Van Maanen 2004, p. 787-794; A.A. van Rossum en M.B. de Witte-van den Haak, 'Staat/Zevenbergen: een grote verwarring', $O \& A$ 2003, p. 52-64; Schueler 2005, p. 172-173; Schueler en Van Ettekoven 2003, p. 168.

190 CRvB 14 maart 2002, $A B$ 2002, 238.

$191 \mathrm{ABRvS} 18$ november 2009, $A B$ 2010, 5 .

192 ABRvS 23 januari 2002, JB 2002, 69.

193 Schlössels 2003, p. 537-541.

194 Schlössels 2004 (I), p. 70-84 en Schlössels 2004 (II), p. 61-78. Ook Tak 2008, p. 1760-1762.

195 Bijvoorbeeld CRvB 28 augustus 2001, JB 2001, 259 en CRvB 7 april 1999, JB 1999, 124.

196 Ook: G.E. Van Maanen, noot bij CRvB 28 augustus 2001, $J B$ 2002, 259 en Van Maanen 2004, p. 787-794.

197 Zoals bijvoorbeeld CRvB 14 maart 2002, $A B$ 2002, 238.

198 Schlössels 2003, p. 537-541; Schlössels 2004(I), p. 70-84 en Schlössels 2004(II), p. 61-78.

199 Over proportionele aansprakelijkheid van toezichthouders zijn de meningen verdeeld. Zie: D. Busch, 'Civielrechtelijke aansprakelijkheid van financiële toezichthouders', in: Busch e.a., Onderneming en financieel toezicht, Deventer: Kluwer 2010, paragraaf 25.7 (I) en D. Busch, Aansprakelijkheid van financiële toezichthouders (Cahier Privaatrecht), Nijmegen: Ars Aequi Libri, p. 49-52 (II) (voorstander); A.A. Van Rossum, 'Civielrechtelijke aansprakelijkheid voor overheidstoezicht', in: Toezicht (Handelingen Nederlandse Juristen-Vereniging, 2005-I), Deventer: Kluwer 2005, p. 95-97 (voorstander); C.L.G.F.H. Albers, 'Overheidsaansprakelijkheid voor gebrekkig toezicht en ontoereikende handhaving', NTBR 2005, p. 482-493 (tegenstander). Zie ook: Giesen en Tjong Tjin Tai 2008, p. 98-99 en Giesen 2005, p. 174-175. Giesen meent dat het op zich niet ondenkbaar is dat de derde die het slachtoffer wordt van het falende toezicht van een toezichthouder in elk geval de kans verloren heeft op een beter resultaat en dat wat dat betreft de proportionele aansprakelijkheid hier een rol zou kunnen vervullen. Giesen denkt wel dat de ruimte voor proportionele aansprakelijkheid bij toezichthouders gering is, omdat causaliteitsproblemen naar zijn mening niet het grootste probleem is bij toezichthoudersaansprakelijkheid en er dus minder behoefte is aan oplossingen op dit vlak.

200 Jurgens 1996, p. 203 en Jurgens NJB 2000, p. 1281. Met betrekking tot aansprakelijkheid van financiële toezichthouders bestaat momenteel een wetsvoorstel, waarin aansprakelijkheid van de AFM en DNB wordt beperkt tot situaties van opzet en grove schuld (Kamerstukken II 2011/12, 33058). In 
gevallen van opzet of grove schuld lijkt mij een hoger percentage aansprakelijkheid gerechtvaardigd. Zie voor een ruimere toerekening bij opzet of grove schuld: HR 25 maart 2011, $A B$ 2011, 223.

201 Zie paragraaf 5.4.

202 Zie Busch 2010(II), p. 59 en J.M. Barendrecht, 'Verdeling van verantwoordelijkheid als het fout gaat, Volendam en Aandelenlease als voorbeelden', NJB 2004, p. 2180-2191.

$\mathbf{2 0 3}$ Zie paragraaf 4.

204 Dit gebeurt wel in $A B R v S 2$ februari 2011, $A B$ 2011, 131. In deze uitspraak wordt de schade als gevolg van een onrechtmatig vrijstellingsbesluit gelijkelijk verdeeld over het bestuursorgaan en appellante, omdat beide partijen in gelijke mate een verwijt valt te maken van het ontstaan van de schade. Appellante had volgens de Afdeling niet voldaan aan de schadebeperkingsplicht.

205 Het is trouwens niet zo dat de bestuursrechter als regel artikel 6:101 BW niet toepast. Er zijn hiervan voldoende voorbeelden. Zie bijvoorbeeld: CRvB 25 februari 2009, LJN BH6077; CRvB 5 augustus 2009, LJN BJ4975; CRvB 3 juni 2009, LJN BI8492; CBb 27 oktober 2006, LJN AZ2218; CRvB 30 september 2009, LJN BJ9051; CRvB 29 april 2010, LJN BM3561; CRvB 12 mei 2005, LJN AT5582 en CBb 17 april 2003, LJN AF8080. Naar mijn mening zou hij dit echter ook in de hier besproken gevallen consequent moeten doen. In de literatuur bestaat overigens wel kritiek op de toepassing van de leerstukken van eigen schuld en schadebeperkingsplicht door de bestuursrechter. Van Maanen en Schlössels menen dat de toepassing van het leerstuk van eigen schuld en (procedurele) schadebeperkingsplicht te ver is doorgeschoten: Van Maanen en Schlössels 2004. Ook Schlössels 2004(II). Volgens Neerhof lijkt de ruimte, die de ABRvS bestuursorganen geeft om een burger ter afwering van een schadeclaim tegen te werpen dat hij de schade posterieur door middel van maatregelen had kunnen beperken, nogal groot: A.R. Neerhof, 'Eigen schuld en de schadebeperkingsplicht in het bestuursrecht', O\&A 2003, p. 99.

206 Bijvoorbeeld: CRvB 14 augustus 2001, JB 2001, 258; CRvB 14 maart 2002, $A B$ 2002, 238; CRvB 19 februari 2009, JB 2009, 103 en CRvB 19 mei 2009, $L J N$ BI6020.

207 CRvB 28 augustus 2001, JB 2001, 259; CRvB 7 april 1999, JB 1999, 124 en CRvB 11 februari 2000, JB 2000, 77.

208 CRvB 11 februari 2000, JB 2000, 77.

209 CRvB 4 mei 2005, JB 2005, 179 en CRvB 21 juni 2005, JB 2005, 240.

210 CRvB 4 mei 2005, JB 2005, 179.

211 Kortmann 2003, p. 15-25. 
212 Van Rossum en De Witte-van den Haak 2003, p. 52-64.

213 Schlössels 2004(II), p. 61-78.

214 Schueler en Van Ettekoven 2003, p. 165-169 en 175.

215 Schueler 2005, p. 172-173.

216 Zie paragraaf 6.1.

217 Ook Van Ravels 2009, p. 14-37.

218 Ook Schueler 2005.

219 Zie paragraaf 6.2.2. Ook Van Rossum en De Witte-van den Haak 2003 en Schueler en Van Ettekoven 2003.

220 Als in zaken tussen private partijen de rechter door toepassing van de criteria van Brunner oordeelt dat aan het toerekeningsvereiste is voldaan, dan doet het feit dat de toerekening kan leiden tot omvangrijke claims over het algemeen aan dat oordeel niet af. Zie paragraaf 6.1. ad 2. en HR 1 juli 1977, NJ 1978,84 .

221 Zie CRvB 4 mei 2005, JB 2005, 179.

222 CRvB 15 april 2009, LJN BI3013.

223 CRvB 27 augustus 2008, $A B$ 2009, 20. Van gelijke strekking is CRvB 18 december 2009, LJN BK7096. In die zaak ging het om een verplichting op basis van een $\mathrm{CAO}$ dat de werkgever slechts 52 weken na de eerste ziekmelding loon behoefde door te betalen. Indien de werkgever langer betaald, is dit een vrije keuze van de werkgever en ontbreekt causaal verband tussen (in casu) de trage besluitvorming en de schade.

224 CRvB 19 februari 2009, $J B$ 2009, 103.

225 Bijvoorbeeld in CRvB 30 december 1998, JB 1999. 53.

226 Schueler en Van Ettekoven 2003, p. 165-169 en 175.

227 Kortmann 2003, p. 17 en Van Maanen en Schlössels 2004, p. 139-144

228 Van Maanen en Schlössels 2004, p. 139-144. Zie ook: Schlössels 2004(II), p. 61-78.

229 Een aanzet daartoe wordt gegeven in het artikel van C.N.J. Kortmann en J.H.A. van der Grinten, 'Artikel 6:98 BW opgepoetst. Een beschouwing over causaliteit als rechtspolitiek alternatief voor de relativiteitsleer.', in: T.

Barkhuysen, W. Den Ouden en M.K.G. Tjepkema (red.), Coulant compenseren?, Deventer: Kluwer 2012. 
230 Brunner 1981, p. 212 en 214; T. Hartlief, 'Schadevergoedingsrecht', in Spier e.a. 2006, p. 244-245; Boonekamp, artikel 98 Boek 6 BW, aant. 29.1 en de daar genoemde literatuur.

231 Bijvoorbeeld HR 5 juni 2009, LJN BH2815.

232 HR 2 november 1979, $N J$ 1980, 77.

233 Zie HR 2 november 1979, NJ 1980, 77. Ook: Boonekamp, artikel 98 Boek 6 BW, aant. 29.3 en Hartlief in Spier e.a. 2006, p. 246.

234 Zie bijvoorbeeld: Hartlief in Spier e.a. 2006, p. 244-245; R.J.B. Boonekamp, 'Door de kat en de hond gebeten', in: Als een goed huisvader (Nieuwenhuis-bundel), Deventer: Kluwer 1992, p. 99 e.v. en C.J.M. Klaassen, Risicoaansprakelijkheid (diss. Nijmegen), Zwolle: W.E.J. Tjeenk Willink 1991, hfdst. 5. Ook Brunner 1981, p. 215-216.

235 CRvB 14 maart 2002, $A B$ 2002, 238.

236 ABRvS 18 november 2009, $A B$ 2010, 5 .

237 ABRvS 23 januari 2002, JB 2002, 69.

238 Bijvoorbeeld CRvB 28 augustus 2001, JB 2001, 259; CRvB 7 april 1999, JB 1999, 124 en CRvB 11 februari 2000, $J B$ 2000, 77. In zijn noot bij deze laatste uitspraak wijst Smits erop dat vanuit puur privaatrechtelijk oogpunt er weinig op tegen is om in casu wel causaal verband aan te nemen. Er is volgens hem zelfs voldaan aan de eis van voorzienbaarheid, omdat voorzienbaar was dat intrekking van de uitkering zou leiden tot de schade.

239 CRvB 28 augustus 2001, JB 2001, 259.

240 CRvB 11 februari 2000, JB 2000,77.

241 HR 6 april 2001, NJ 2001, 333.

242 Kortmann 2003, p. 15-25.

243 Kortmann verwijst hiervoor naar CRvB 17 juni 1998, JB 1998, 189. Deze uitspraak wordt hierna onder $\mathrm{c}$ behandeld.

244 Noot bij CRvB 28 augustus 2001, $J B$ 2002, 259 en Van Maanen 2004, p. 787-794.

245 Van Maanen 2004, p. 787-794.

246 Zie de noot bij CRvB 11 februari 2000, $J B$ 2000, 77.

247 CRvB 21 juni 2005, JB 2005, 240. 
248 O.a. HR 8 februari 1985, $N J$ 1986, 137.

249 Bijvoorbeeld wel een ruime toerekening in HR 1 juli 1993, NJ 1993, 667, waarin de zorgvuldigheidsnorm van goed werkgeverschap was geschonden. Daarentegen geen ruime toerekening in HR 2 november, $N J$ 1980, 77. In deze zaak ging het om een (verondersteld) onrechtmatige bejegening van een arts en zijn ziekenhuis jegens een vader wiens dochter in coma was geraakt tijdens een operatie.

250 CRvB 21 juni, JB 2005, 240.

251 CRvB 4 mei 2005, JB 2005, 179.

252 CRvB 19 mei 2009, LJN BI6020.

253 Dit geldt mijns inziens ook voor CRvB 18 juli 1997, $A B$ 1997, 358 waar het psychisch letsel volgens de Raad werd veroorzaakt door voorafgaand ontslag van de werkgever en het verleden van de benadeelde en dus niet door het onrechtmatige besluit. Zie over dit onderwerp ook paragraaf 4 .

254 ABRvS 31 maart 2000, JB 2000, 137.

255 CRvB 14 augustus 2001, $J B$ 2001, 258.

256 CRvB 17 juni 1998, JB 1998, 189.

257 ABRvS 6 februari 2002, $A B$ 2002, 257.

258 Van Maanen en Schlössels 2004, p. 139-144. Ook: Schlössels 2004 (I), p. 70-84 en Schlössels 2004 (II), p. 61-78.

259 Schlössels 2003, p. 537-541.

260 Hennekens sprak over de waarschijnlijkheidsleer: noot bij CRvB 17 juni 1999, $A B$ 1999, 348.

261 Schlössels verwijst naar zie HR 7 november 1997, $A B$ 1998, 221: Schlössels 2003, p. 537-541. Ook: Schlössels 2004 (I), p. 70-84 en Schlössels 2004 (II), p. 61-78.

262 Hij wijst op ABRvS 1 juni 1999, JB 1999, 192; ABRvS 18 mei 1999, JB 1999, 215 en CRvB 28 augustus 2001, JB 2001, 259.

263 Schlössels, 2004 (II), p. 61-78. Ook Tak 2008, p. 1760-1762.

264 Schlössels, 2004 (I), p. 70-84 en Schlössels 2004 (II), p. 61-78. Ook Tak 2008, p. 1760-1762.

265 Schlössels 2004 (I), p. 70-84. 
266 Schlössels 2004 (II), p. 61-78.

267 Ook Tak 2008, p. 1760-1762.

268 G.M.J.M. Jurgens, Bestuurlijk gedogen. Aanvaardbaarheid en gevolgen van bestuurlijk gedogen in het milieurecht en het ruimtelijk recht, Zwolle: Tjeenk Willink 1996, p. 203 en G.M.T. Jurgens, 'Overheidsaansprakelijkheid bij gedogen?', NJB 2000, p. 1281.

269 Zie hierover paragraaf 4.

270 Alleen in de besproken zaak waarin niet werd gehandhaafd bij illegaal houden van bijen zou het condicio sine qua non verband misschien een punt van discussie kunnen zijn, omdat niet direct duidelijk is of ook bij correcte handhaving de schade ten gevolge van het illegaal houden van bijen al dan niet in gelijke mate - zou zijn geleden: ABRvS 18 november 2009, $A B$ 2010, 5 .

271 Zie bijvoorbeeld HR 23 september 1988, NJ 1989, 743 en HR 15 februari 1991, $A B$ 1991, 394.

272 Zie paragraaf 5.4 .

273 Ook: Schueler en Van Ettekoven 2003, p. 166.

274 CRvB 14 maart 2002, $A B$ 2002, 238. Zie ook de annotator H.E. Bröring: hem lijkt deze eis te streng.

275 ABRvS 23 januari 2002, JB 2002, 69. Zie ook CBb 29 juli 1997, $A B$ 1997,447 ('rechtstreeks en onmiddellijk'); ABRvS 18 mei 2005, LJN AT5690 ('rechtstreeks') en 18 november 2009, AB 2010, 5 ('rechtstreeks').

276 HR 2 oktober 1998, NJ 1998, 831.

277 Zelfs stagnatieschade wordt bijvoorbeeld niet als regel uitgesloten van vergoeding. Zie paragraaf 6.1. ad 2. en HR 1 juli 1977, $N J$ 1978, 84. Ook: HR 2 oktober 1998, $N J$ 1998, 831.

278 Ook: Van Maanen 2004, p. 787-794; A.A. van Rossum en M.B. de Witte-van den Haak, 'Staat/Zevenbergen: een grote verwarring', O\&A 2003, p. 52-64; Schueler 2005, p. 172-173; Schueler en Van Ettekoven 2003, p. 168.

279 CRvB 14 maart 2002, $A B$ 2002, 238.

280 ABRvS 18 november 2009, $A B$ 2010, 5 .

281 ABRvS 23 januari 2002, JB 2002, 69.

282 Schlössels 2003, p. 537-541.

283 Schlössels 2004 (I), p. 70-84 en Schlössels 2004 (II), p. 61-78. Ook Tak 
2008, p. 1760-1762.

284 Bijvoorbeeld CRvB 28 augustus 2001, JB 2001, 259 en CRvB 7 april 1999, JB 1999, 124.

285 Ook: G.E. Van Maanen, noot bij CRvB 28 augustus 2001, JB 2002, 259 en Van Maanen 2004, p. 787-794.

286 Zoals bijvoorbeeld CRvB 14 maart 2002, $A B$ 2002, 238.

287 Schlössels 2003, p. 537-541; Schlössels 2004(I), p. 70-84 en Schlössels 2004(II), p. 61-78.

$\mathbf{2 8 8}$ Over proportionele aansprakelijkheid van toezichthouders zijn de meningen verdeeld. Zie: D. Busch, 'Civielrechtelijke aansprakelijkheid van financiële toezichthouders', in: Busch e.a., Onderneming en financieel toezicht, Deventer: Kluwer 2010, paragraaf 25.7 (I) en D. Busch, Aansprakelijkheid van financiële toezichthouders (Cahier Privaatrecht), Nijmegen: Ars Aequi Libri, p. 49-52 (II) (voorstander); A.A. Van Rossum, 'Civielrechtelijke aansprakelijkheid voor overheidstoezicht', in: Toezicht (Handelingen Nederlandse JuristenVereniging, 2005-I), Deventer: Kluwer 2005, p. 95-97 (voorstander); C.L.G.F.H. Albers, 'Overheidsaansprakelijkheid voor gebrekkig toezicht en ontoereikende handhaving', NTBR 2005, p. 482-493 (tegenstander). Zie ook: Giesen en Tjong Tjin Tai 2008, p. 98-99 en Giesen 2005, p. 174-175. Giesen meent dat het op zich niet ondenkbaar is dat de derde die het slachtoffer wordt van het falende toezicht van een toezichthouder in elk geval de kans verloren heeft op een beter resultaat en dat wat dat betreft de proportionele aansprakelijkheid hier een rol zou kunnen vervullen. Giesen denkt wel dat de ruimte voor proportionele aansprakelijkheid bij toezichthouders gering is, omdat causaliteitsproblemen naar zijn mening niet het grootste probleem is bij toezichthoudersaansprakelijkheid en er dus minder behoefte is aan oplossingen op dit vlak.

289 Jurgens 1996, p. 203 en Jurgens NJB 2000, p. 1281. Met betrekking tot aansprakelijkheid van financiële toezichthouders bestaat momenteel een wetsvoorstel, waarin aansprakelijkheid van de AFM en DNB wordt beperkt tot situaties van opzet en grove schuld (Kamerstukken II 2011/12, 33058). In gevallen van opzet of grove schuld lijkt mij een hoger percentage aansprakelijkheid gerechtvaardigd. Zie voor een ruimere toerekening bij opzet of grove schuld: HR 25 maart 2011, $A B$ 2011, 223.

$\mathbf{2 9 0}$ Zie paragraaf $5 \cdot 4$.

291 Zie Busch 2010(II), p. 59 en J.M. Barendrecht, 'Verdeling van verantwoordelijkheid als het fout gaat, Volendam en Aandelenlease als voorbeelden', NJB 2004, p. 2180-2191.

292 Zie paragraaf 4 .

293 Dit gebeurt wel in ABRvS 2 februari 2011, $A B$ 2011, 131. In deze uitspraak 
wordt de schade als gevolg van een onrechtmatig vrijstellingsbesluit gelijkelijk verdeeld over het bestuursorgaan en appellante, omdat beide partijen in gelijke mate een verwijt valt te maken van het ontstaan van de schade. Appellante had volgens de Afdeling niet voldaan aan de schadebeperkingsplicht.

294 Het is trouwens niet zo dat de bestuursrechter als regel artikel 6:101 BW niet toepast. Er zijn hiervan voldoende voorbeelden. Zie bijvoorbeeld: CRvB 25 februari 2009, LJN BH6077; CRvB 5 augustus 2009, LJN BJ4975; CRvB 3 juni 2009, LJN BI8492; CBb 27 oktober 2006, LJN AZ2218; CRvB 30 september 2009, LJN BJ9051; CRvB 29 april 2010, LJN BM3561; CRvB 12 mei 2005, LJN AT5582 en CBb 17 april 2003, LJN AF8080. Naar mijn mening zou hij dit echter ook in de hier besproken gevallen consequent moeten doen. In de literatuur bestaat overigens wel kritiek op de toepassing van de leerstukken van eigen schuld en schadebeperkingsplicht door de bestuursrechter. Van Maanen en Schlössels menen dat de toepassing van het leerstuk van eigen schuld en (procedurele) schadebeperkingsplicht te ver is doorgeschoten: Van Maanen en Schlössels 2004. Ook Schlössels 2004(II). Volgens Neerhof lijkt de ruimte, die de ABRvS bestuursorganen geeft om een burger ter afwering van een schadeclaim tegen te werpen dat hij de schade posterieur door middel van maatregelen had kunnen beperken, nogal groot: A.R. Neerhof, 'Eigen schuld en de schadebeperkingsplicht in het bestuursrecht', $O \& A$ 2003, p. 99.

295 Bijvoorbeeld: CRvB 14 augustus 2001, JB 2001, 258; CRvB 14 maart 2002, $A B$ 2002, 238; CRvB 19 februari 2009, $J B$ 2009, 103 en CRvB 19 mei 2009, LJN BI6020.

296 CRvB 28 augustus 2001, $J B$ 2001, 259; CRvB 7 april 1999, $J B$ 1999, 124 en CRvB 11 februari 2000, JB 2000, 77.

297 CRvB 11 februari 2000, $J B$ 2000, 77.

298 CRvB 4 mei 2005, JB 2005, 179 en CRvB 21 juni 2005, JB 2005, 240.

299 CRvB 4 mei 2005, JB 2005, 179.

300 Kortmann 2003, p. 15-25.

301 Van Rossum en De Witte-van den Haak 2003, p. 52-64.

302 Schlössels 2004(II), p. 61-78.

303 Schueler en Van Ettekoven 2003, p. 165-169 en 175.

304 Schueler 2005, p. 172-173.

305 Zie paragraaf 6.1.

306 Ook Van Ravels 2009, p. 14-37.

307 Ook Schueler 2005. 
308 Zie paragraaf 6.2.2. Ook Van Rossum en De Witte-van den Haak 2003 en Schueler en Van Ettekoven 2003.

309 Als in zaken tussen private partijen de rechter door toepassing van de criteria van Brunner oordeelt dat aan het toerekeningsvereiste is voldaan, dan doet het feit dat de toerekening kan leiden tot omvangrijke claims over het algemeen aan dat oordeel niet af. Zie paragraaf 6.1. ad 2. en HR 1 juli 1977, NJ 1978,84 .

310 Zie CRvB 4 mei 2005, JB 2005, 179.

311 CRvB 15 april 2009, LJN BI3013.

312 CRvB 27 augustus 2008, $A B$ 2009, 20. Van gelijke strekking is CRvB 18 december 2009, LJN BK7096. In die zaak ging het om een verplichting op basis van een CAO dat de werkgever slechts 52 weken na de eerste ziekmelding loon behoefde door te betalen. Indien de werkgever langer betaald, is dit een vrije keuze van de werkgever en ontbreekt causaal verband tussen (in casu) de trage besluitvorming en de schade.

313 CRvB 19 februari 2009, JB 2009, 103.

314 Bijvoorbeeld in CRvB 30 december 1998, JB 1999. 53.

315 Schueler en Van Ettekoven 2003, p. 165-169 en 175.

316 Kortmann 2003, p. 17 en Van Maanen en Schlössels 2004, p. 139-144

317 Van Maanen en Schlössels 2004, p. 139-144. Zie ook: Schlössels 2004(II), p. 61-78.

318 Een aanzet daartoe wordt gegeven in het artikel van C.N.J. Kortmann en J.H.A. van der Grinten, 'Artikel 6:98 BW opgepoetst. Een beschouwing over causaliteit als rechtspolitiek alternatief voor de relativiteitsleer.', in: T.

Barkhuysen, W. Den Ouden en M.K.G. Tjepkema (red.), Coulant compenseren?, Deventer: Kluwer 2012. 
